
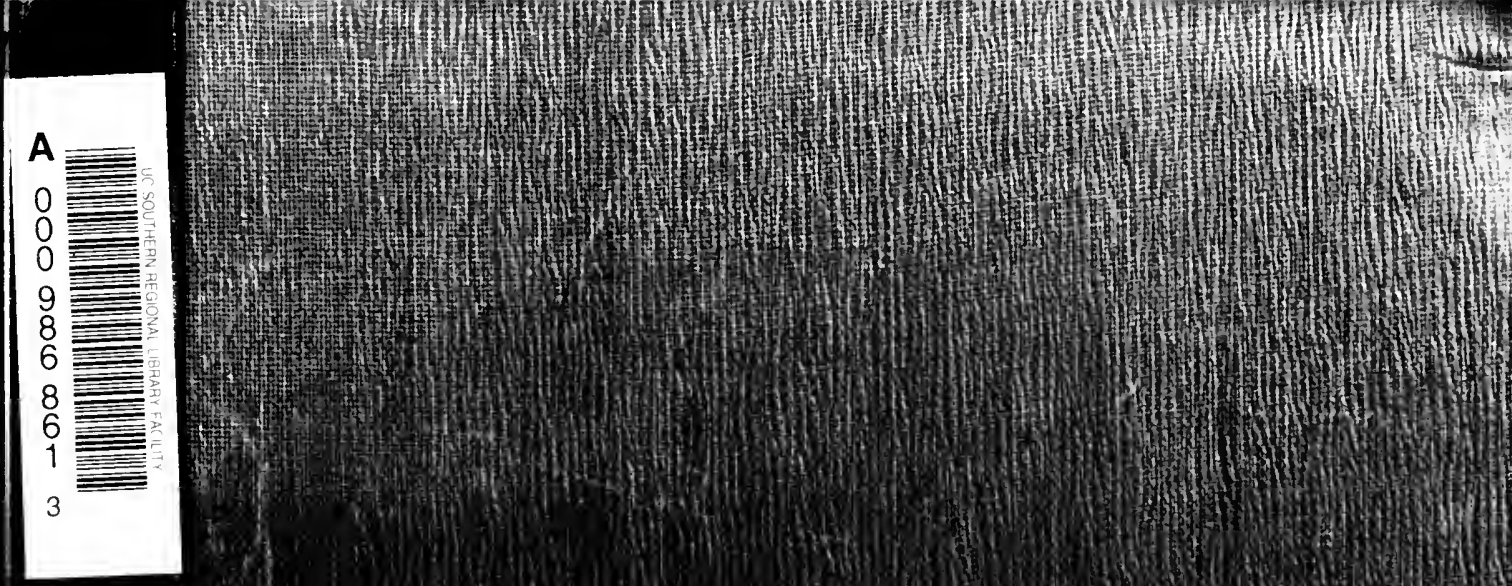

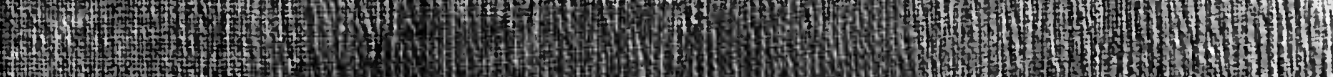

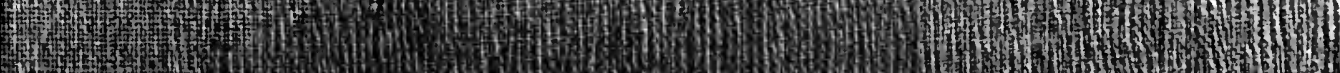
(1)

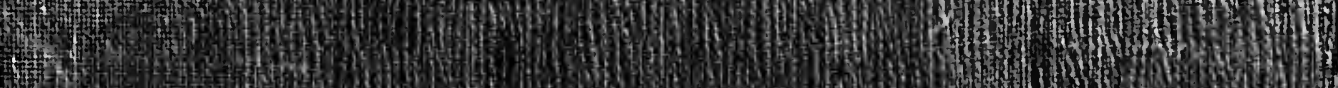
H.

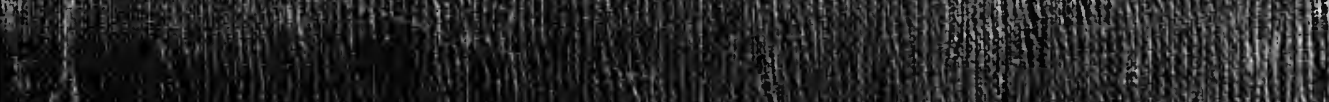
C.s.
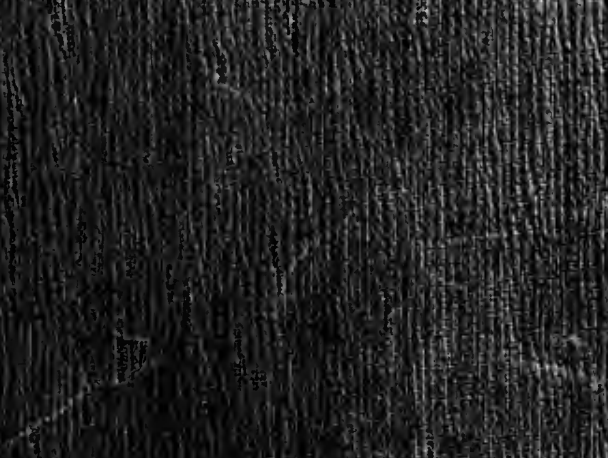

t)
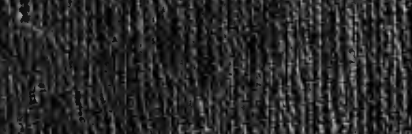

(6)
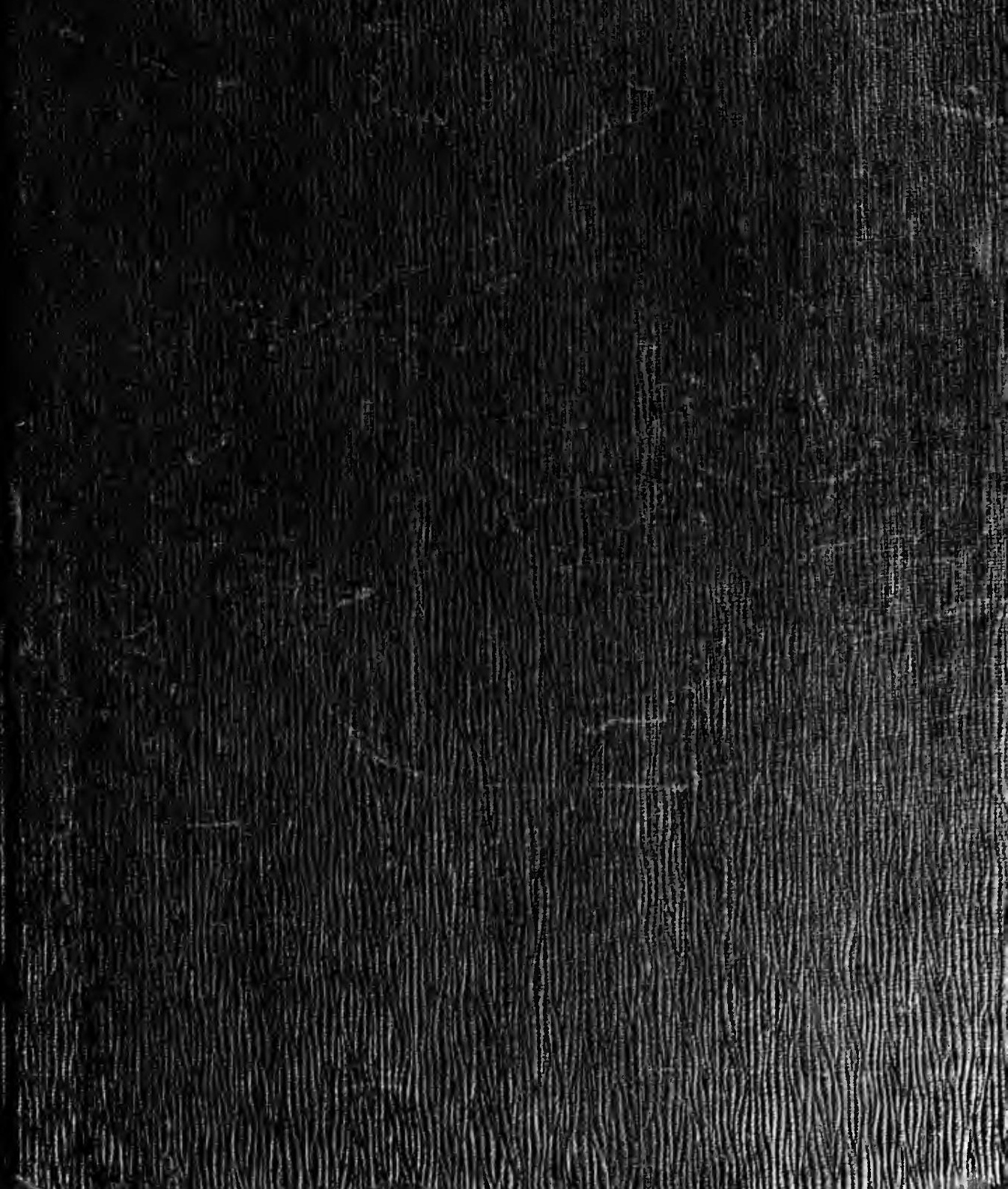
(5)) 1)

r.t.

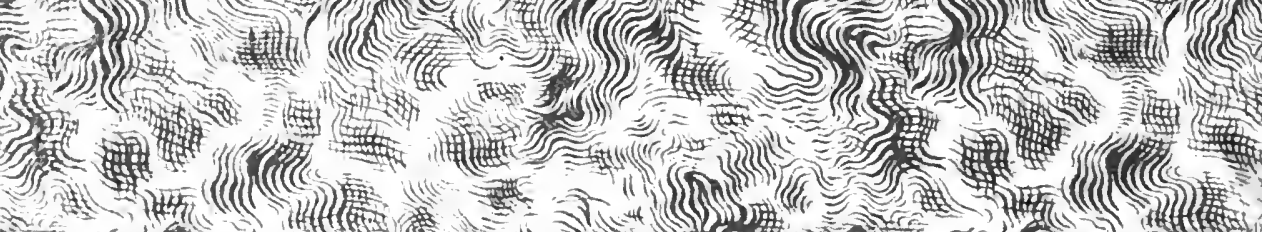
aid

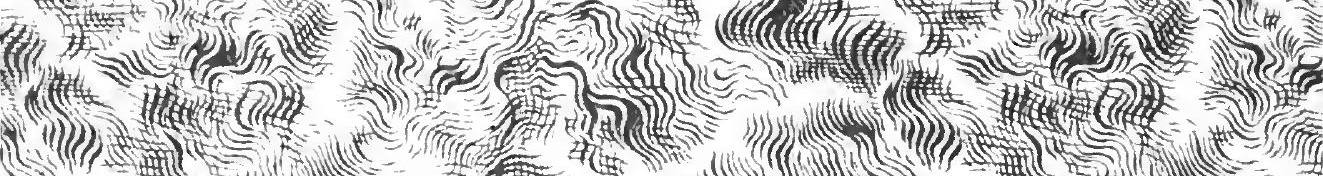

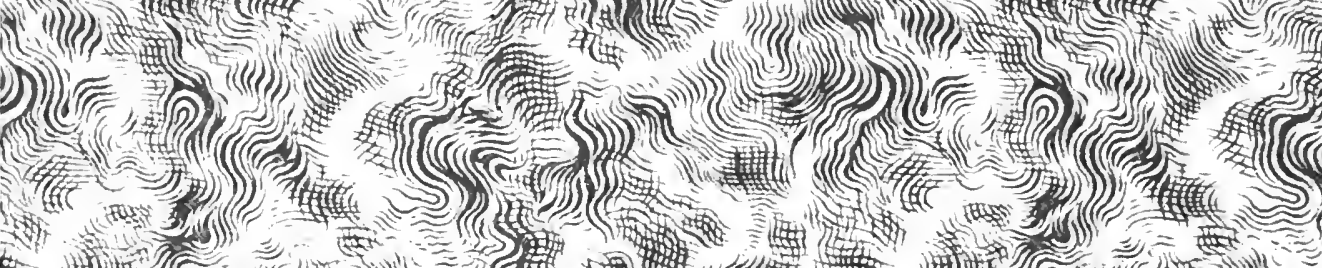
(n)

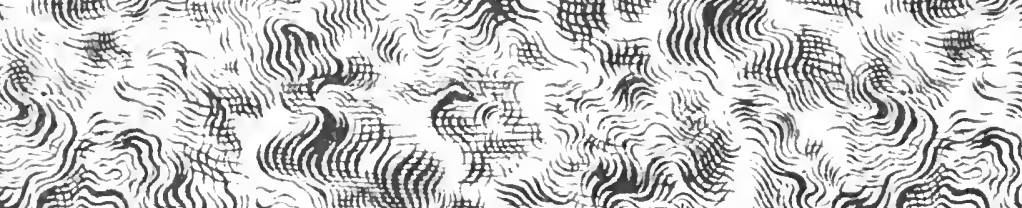

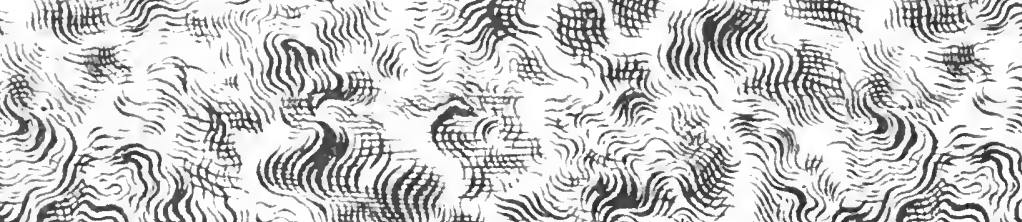

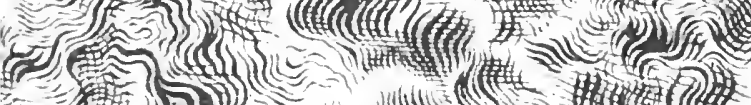

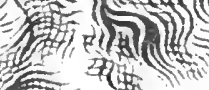

sing

徏
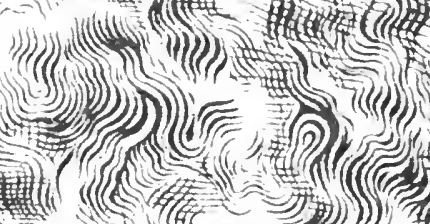

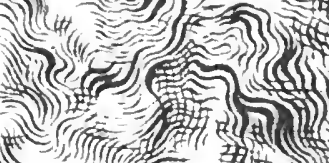
$((t), y)$

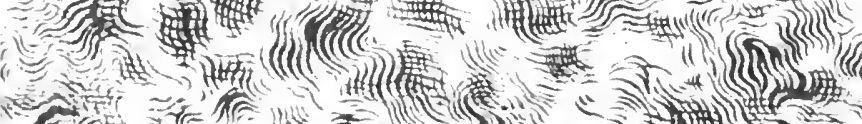
t)

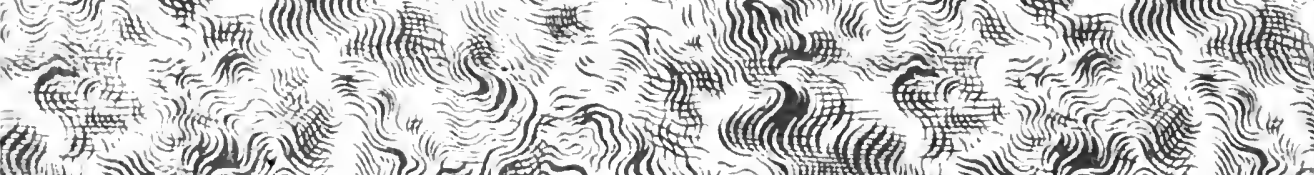

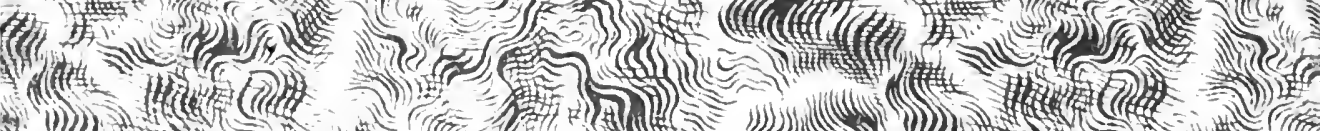

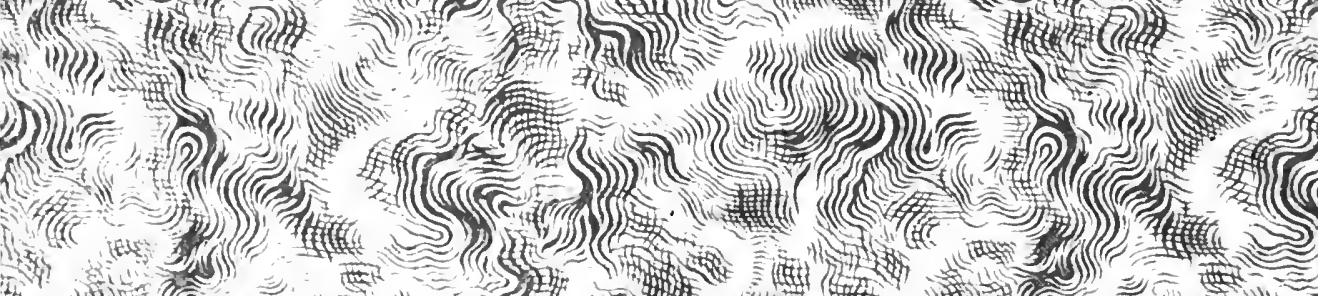

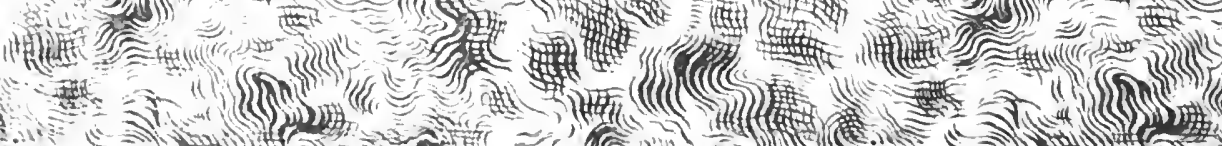

3)

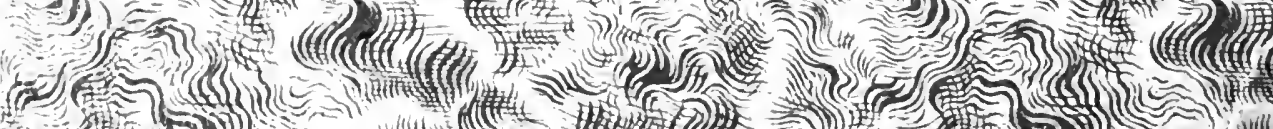





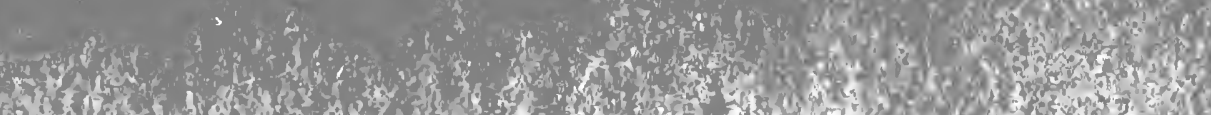

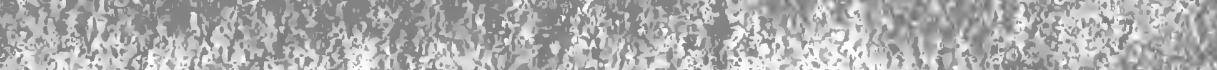

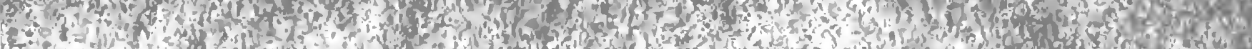

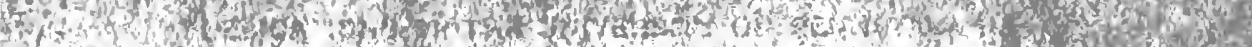

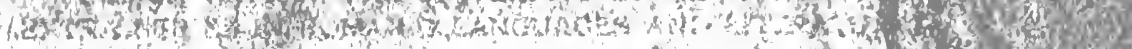

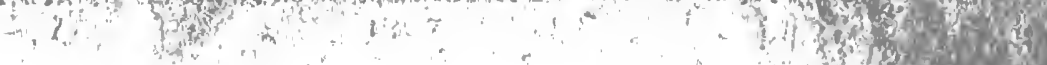
(3)

is

a

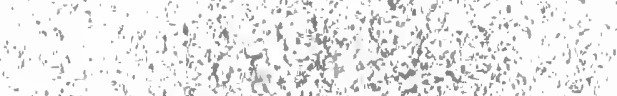

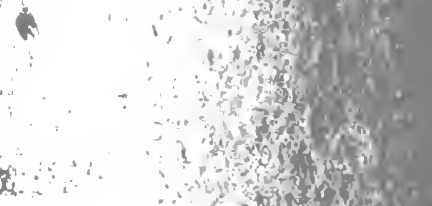

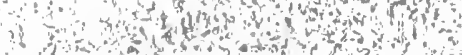

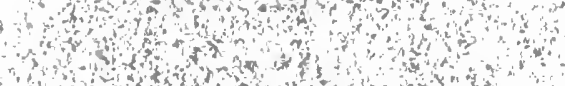

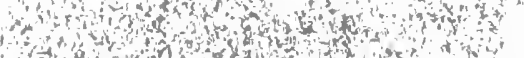

2

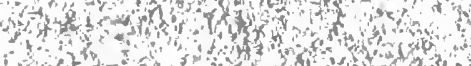

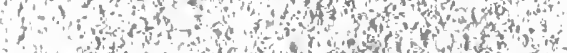

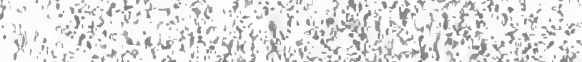

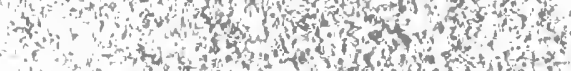

$\therefore$ ond

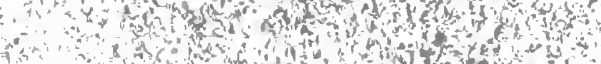

(n)

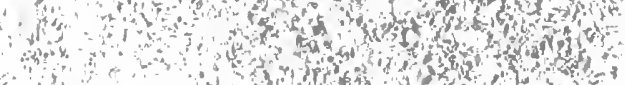

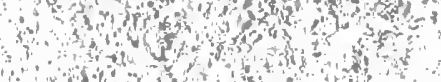

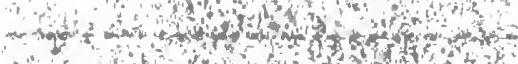

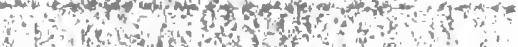

$2-y_{0}$

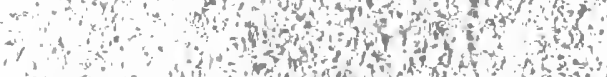

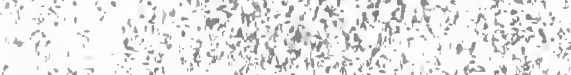

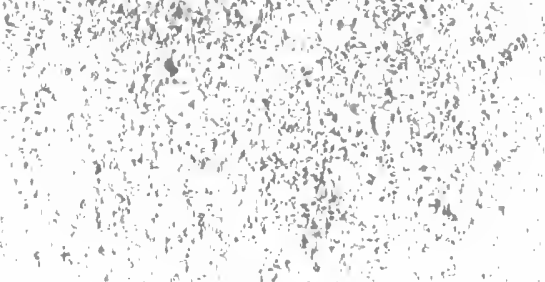

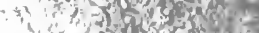

* on

ing

$2+1004=$

$1^{2}+1,10$

1. platers.

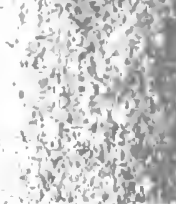

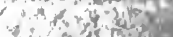

kns

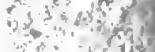




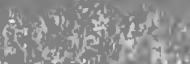

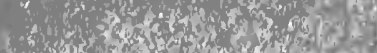

2.

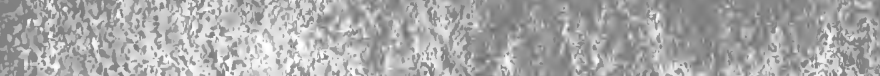

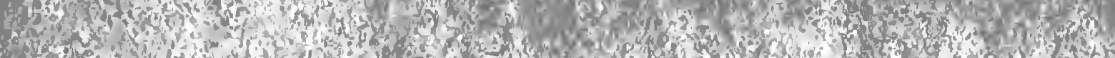

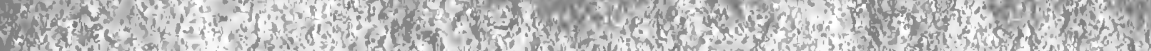

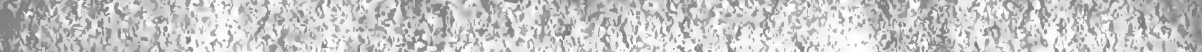

4.

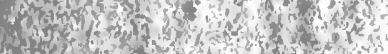

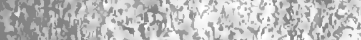

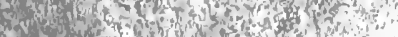

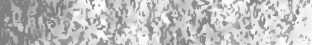

ty

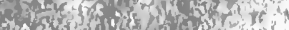

Ansulfor

$\sin ^{2}$ sing

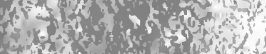

thom on a d o s

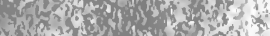

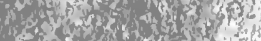

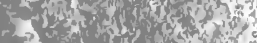

ton +20

a. ${ }^{2}$,

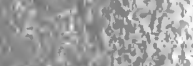

towis ons

tous ans a

Thes ting

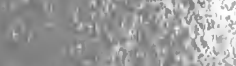

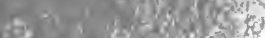

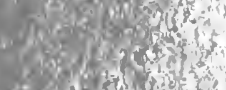

hom

(n)

in

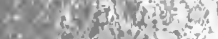

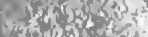

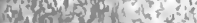

$\rightarrow$ on

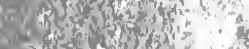

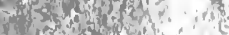

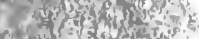

A 30 ?

ald

Tow

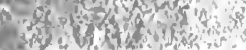

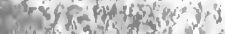

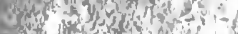

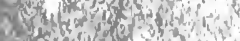

Solnow

Fe forish

+

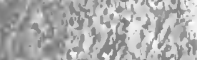

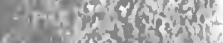

ont

$5 x$ in w y not

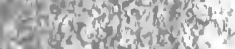

2.

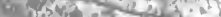

$2 x+8$ ans $15 \%$

is

Hostion

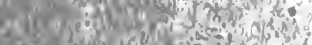

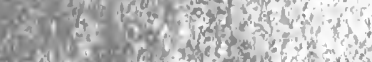

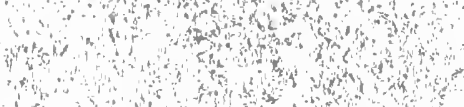

a d

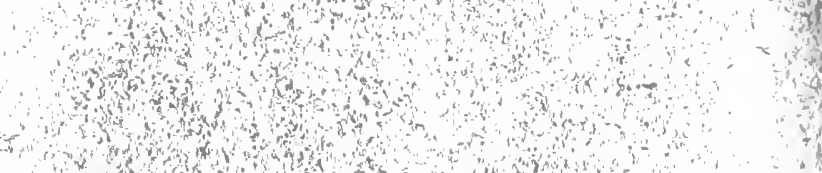

3) 


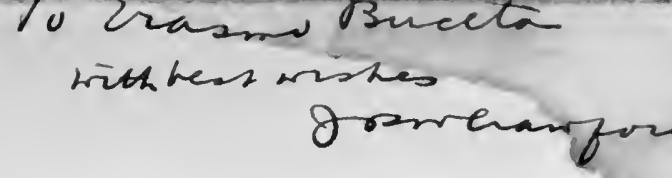

PUBLICATIONS OF THE UNIVERSITY OF PENNSYLVANIA EXTRA SERIES IN ROMANIC LANGUAGES AND LITERATURES. No. 7

\section{SPANISH DRAMA BEFORE LOPE DE VEGA}

BY

J. P. WICKERSHAM CRAWFORD, Pr.D. PROFESSOR OF ROMANIC LANGUAGES AND LITERATURES IN THE UNIVERSITY OF PENNSYLVANIA 
PUBLICATIONS OF THE UNIVERSITY OF PENNSYLVANIA DEPARTMENT OF ROMANIC LANGUAGES AND LITERATURES Extra Series, No. 7 


\section{an}

MY WIFE

MAY WICKERSHAM CRAWFORD

THIS LITTLE VOLUME IS AFFECTIONATELY DEDICATED 
Digitized by the Internet Archive in 2007 with funding from Microsoft Corporation 


\section{PREFACE}

SEvENTY years have passed since the first appearance of 'Adolph Friedrich von Schack's Geschichte der dramatischen Literatur und Kunst in Spanien, the first part of which was devoted to a study of the predecessors of Lope de Vega, and while many critical studies have been written upon individual dramatists and many plays, not mentioned by Schack, have been discovered and published, no attempt has been made since that time to write a history of the earlier Spanish drama. Limitations of space have prevented me from attempting to write a detailed history of the Spanish drama before Lope de Vega, but I have tried to give at least an outline of the development of dramatic literature in that period. I am fully aware of the fact that the picture which I present is incomplete, but it is my hope that I have succeeded in presenting here the results of the studies of my many predecessors, as well as of my own reading, and that this little book will serve as a starting-point for further investigation in a subject that offers: so much of interest.

I have limited myself to a consideration of the drama in the Spanish language, and have, therefore, paid little attention to the plays of that period written in Catalan and Valencian. With considerable regret, I have included only the Castilian. plays of Gil Vicente, and the plays in which the Castilian: element seems to predominate, and I have not even touched. upon the many disputed points in the biography of the great Portuguese poet.

I wish to express my gratitude to my friend and colleague, Professor Hugo A. Rennert, for his kindness in reading my manuscript. It is to him that I owe my first interest in this. 
subject, and the inspiration which $I$ have received from his labours and from our many chats regarding our favourite Spanish dramatic poets has been a powerful incentive to me in my own studies.

J. P. W. C. 


\section{CONTENTS}

CHAPTER I

The Spanish Drama Before Encina.

CHAPTER II

Juan Del Encina................................ 20

CHAPTER III

Religious Drama Before Lope de Rueda................ 39

CHAPTER IV

Festival and Pastoral Plays $\ldots \ldots \ldots \ldots \ldots \ldots \ldots \ldots \ldots \ldots \ldots \ldots \ldots, 65$

CHAPTER V

Romantic Comedy and the Comedy of Manners Before Lope de

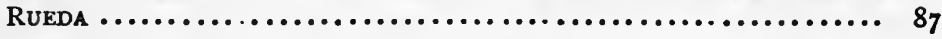

CHAPTER VI

Lope de RUeda, Italianate Comedy and the Farce............ Ii

CHAPTER VII

Religious Drama in the Latter Half of the Sixtrenth Century.... I 37

CHAPTER VIII

Tragedy and Later Comedy........................... 152

Bibliography.................................... I 83 



\section{CHAPTER I}

\section{The Spanish Drama Before Encina}

Although material is almost entirely lacking for a study of the liturgical drama in Spain, the close relationship that existed between the ritual of the Spanish church and that of other countries of Western Europe, and particularly of France after the eleventh century, allows us to assume that in Spain, as elsewhere, the religious drama developed from the tropes attached to the Introit of the Magna Missa of Easter and Christmas. To the study of the origins of the medieval liturgical drama, Castilian-speaking portions of the Peninsula contribute only an eleventh or twelfth-century Christmas trope of a primitive type from Huesca, ${ }^{1}$ and two eleventh-century Easter tropes from Silos. ${ }^{2}$

In spite of this noteworthy lack of liturgical texts, Spanish literature may claim the honor of possessing in the Auto de los Reyes Magos one of the earliest, if not the earliest religious play in a modern tongue. This composition, consisting of I 46 or 147 lines, is contained in a manuscript of the Chapter Library of Toledo, now preserved at the National Library of Madrid, and on the basis of linguistic and scribal considerations may be ascribed to the middle of the twelfth century. It was probably performed in some church in the city of Toledo to celebrate the festival of the Epiphany. With respect to its origin, it is difficult to determine whether its pro-

${ }^{1}$ Mentioned by Karl Young, Officium Pastorum: A Study of the Dramatic Developments within the Liturgy of Christmas, Transactions of the Wisconsin Academy of Sciences, Arts and Letters, vol. xvii, pt. ii, I9r4, p. 300n.

2 Carl Lange, Die lateinischen Osterfeiern, Munich, 1887, p. 24. 
totype is a play in French or a liturgical text of the Officium Stellae such as was used at Limoges, Rouen, Nevers, Compiègne and Orléans in the twelfth century, and which might have been introduced into Spain by the Benedictines of Cluny. If its source is really one of these Latin texts, the author derived from it merely the arrangement of incidents, and treated his material with independence, originality and dramatic sense. Instead of the five lines recited by the Magi, in several of the liturgical texts, before their meeting with Herod, we find three monologues in the Spanish play, amounting to fifty-one lines, in which the author attempts to give some individuality to the Wise Kings by describing their doubts as to whether the new star in the heavens really betokens the Saviour's birth. The following scene, in which the Magi confer with one another concerning the meaning of the star, is not found in any liturgical text. Furthermore, the gifts of the Magi are spoken of as a means to identify the Christ Child. He will choose gold if a king of this world, myrrh if he is a mortal man and incense if he is King of Heaven. These occur in the Hymnus Epiphaniae of Prudentius, a few stanzas of which were included in the Breviary. ${ }^{1}$

In the third scene they appear before Herod who, on learning the object of their quest, bids them go and search for the new King, and when they have found Him, to bring him word again so that he may go and worship also. When left alone, Herod becomes the ranting tyrant who appears in so many later plays and summons his scribes and astrologers to interpret for him this mystery. They fall into a dispute and the play breaks off abruptly. We may assume that at least one scene, namely, the Adoration of the Christ Child by the Magi, has been lost. Like the Old French and Latin pieces of like character, it has a rich metrical structure with enneasyllabic and heptasyllabic verses and Alexandrines as the prevailing measures.

${ }^{1}$ A. Bonilla y San Martin, Las Bacantes, o del origen del teatro, Madrid, I92I, p. 72. 
An oft-quoted law of the Siete Partidas ${ }^{1}$ (1256-1263) gives us valuable information concerning religious plays in Spain about the middle of the thirteenth century. After prohibiting certain abuses that will be discussed later, the law expressly declares that members of the clergy are permitted to present (fazer) plays (representaciones) that deal with the birth of Jesus and the announcement of the angel to the shepherds, the Adoration of the Magi and the Resurrection. Such Christmas, Epiphany and Easter plays were allowed with reasonable restrictions, and their function as a vehicle of religious instruction is clearly recognized. The words of the text indicate that these plays contained dialogue and were accompanied by a crude attempt at acting, and the ban laid upon performances in small towns or for the sake of gain, seems to prove that they were composed in Spanish.

The history of the religious drama during the two hundred years that followed upon the Siete Partidas is shrouded in almost complete obscurity. Not a single Castilian play is known to have been composed during those two centuries that witnessed the unfolding and culmination of the English miracle plays and the French miracles and mystères. Furthermore, even the few allusions to dramatic performances during that period that have been discovered, refer almost entirely to Catalan and Valencian territory. For example, a document of the year 1360 informs us that it was customary for the canons of the Cathedral of Gerona to perform on Easter a play called Las tres Marias. ${ }^{2}$ A primitive Christmas representation is first mentioned at Valencia in 1432 and dialogue was introduced by the year $1440 .^{3}$ It is well known that Corpus Christi day was celebrated throughout Western

1 Las Siete Partidas del Rey don Alfonso el Sabio, vol. i, Madrid, 1897, pt. i, tit. vi, ley 34.

${ }^{2}$ Schack, Historia de la literatura y del arte dramático en España, vol. i, p. 224.

' For early religious shows at Valencia, see Henri Mérimée, L'Art dramatique à Valencia, Toulouse, 1913, pp. 1-19. 
Europe in the first half of the fourteenth century by a procession in which religious bodies and guilds escorted the Host through the streets, and Catalan and Valencian documents attest the popularity of that festival. Sacred scenes were sometimes represented, as for example, the Sacrificio de Isaac and Sueño $y$ venta de Jacob, by the beneficiaries of the Cathedral of Gerona on Corpus Christi day, $1360,{ }^{1}$ and references to the Corpus procession at Valencia date back to 1355. This ceremony became increasingly important as a religious and municipal festival and at the beginning of the fifteenth century pageants, called "entrames" and "roca," were constructed to carry singers and musicians, dressed as angels, patriarchs and saints, about the city. These pageants were only moving shows and probably employed dialogue solely to supplement the living picture. We have no evidence that pageants were similarly employed in the Castilian-speaking portions of the Peninsula before the latter half of the fifteenth century, at which time they formed a part of the Corpus procession at Seville. ${ }^{2}$

A passage in the Cronica del Condestable Miguel Lucas de Iranzo ${ }^{3}$ gives us an idea of the presentation of religious shows in the palaces of noblemen in the fifteenth century. On Twelfth Night, 1462, the visit of the Magi bringing gifts to the Virgin and Child was represented, and we are told that this ceremony took place each year. The brief description that we possess does not allow us to judge whether dialogue was employed, but it gives evidence of a practice that was to develop into drama, thirty years later, in the hands of Juan del Encina.

More than three hundred years separate the Auto de los Reyes Magos and Gómez Manrique's Representacion del nacimiento de nuestro Señor, the earliest extant example of

${ }^{1}$ Schack, op. cit., vol. i, p. 223 .

2 José Sánchez-Arjona, Noticias referentes a los anales del teatro en Sevilla, Sevilla, 1898, pp. 3-6.

-Memorial histórico español, vol. viii, Madrid, 1855, pp. 75-76. 
the Officium Pastorum in Spain. Like his distinguished contemporary, the Marqués de Santillana, Gómez Manrique was a gallant soldier and an important figure in the political life of his day, as well as a gifted poet. His Cancionero is made up almost entirely of lyrical verse, in which he was excelled only by the Marqués de Santillana and Juan de Mena. His Christmas play was composed between 1467 and $148 \mathrm{I}$ to provide entertainment for the nuns at the convent of Calabazanos where his sister Maria was mother assistant. It presents in simple, unaffected style and with a spirit of true devotion, the familiar incidents of the Christmas story. Joseph doubts the purity of Mary, and an angel explains that she is the Virgin of whom Isaiah prophesied. The Mother tenderly worships the Child Jesus, mingling joy over his birth with tears for the pains that he must endure. Shepherds, obeying the angel's summons, come to the manager to worship, and kneeling before the Child proclaim him the Redeemer, while a choir of angels sings or recites the Gloria in Excelsis. St. Gabriel, St. Michael and St. Raphael then present to the Child the tokens of his Passion, the chalice, the pillar and cords, the scourges, the crown, the cross, the nails and lance, a bit of symbolism that we find again in the sixteenth-century Aucto de las donas. This is followed by a charming lullaby composed on a popular air and sung in chorus by the nuns.

This little piece shows slight progress in dramatic art over the Auto de los Reyes Magos. Dialogue is introduced only in a brief scene when the shepherds discuss the meaning of the angel's song. In the rest of the play, each character merely recites a stanza or two and then withdraws. While it preserves no liturgical elements and is completely secular, the tone throughout is devout.

A better idea of the sort of Christmas plays of the time that served to entertain an audience of peasants and tradespeople in the churchyard, may be obtained from a few scenes of Fr. Iñigo de Mendoza's Vita Christi, first published about 1480. After explaining the mysteries of the Incarnation and An- 
nunciation, the devotional tone abruptly changes on reaching the incidents of the Nativity. Four shepherds are terrorstricken by the appearance of a figure that seems to fly through the air. They would like to hurry to town to tell the news, but some are too frightened to move and the others are afraid of being taken for drunkards or fools. While they are still disputing, the angel appears again, announces the birth of the Redeemer of mankind, and bids them worship him in the doorway where the beasts of burden are tied. The shepherds finally recover from their fright and make ready to obey the summons. Off in the distance they see a strange light and hear the gentle voice of a Maiden singing to her new-born Child. They set out taking with them pipe and reed and rebec to honor the Child as best they can, and gifts for the Mother. In the following scene, one of the shepherds describes the song of the angels at the manger in praise of the Christ.

These scenes are in dialogue form, and the author's comments serve to show their relationship to each other. The rustic language employed recalls the Coplas de Mingo Revulgo as well as the shepherds' speech that we find in the plays of Encina and other dramatists in the first half of the following century. Apparently, even at this time, the shepherd was the chief comic figure in the secularized religious drama. In the mingling of sacred and humorous elements, as well as in the use of rustic language, Iñigo de Mendoza was a precursor of Encina. In both cases the poets probably borrowed these features from popular performances which they themselves had often witnessed.

Judging from an expense account that has been preserved of a Christmas play or show presented in 1487 in the Cathedral of Saragossa, ${ }^{1}$ costumes and scenic effects were not wholly disregarded. An ox and an ass were represented at the manger; the prophets were provided with wigs and the angels with gloves as well, and there was a throne for the

${ }^{1}$ Schack, op. cit., vol. i, pp. 267-268. 
Virgin. The Chapter paid five florins to the stage-director and two florins to the man, woman and child who played the parts of Mary, Joseph and Jesus. We do not know whether there was any dialogue, nor whether the platforms mentioned in the text were stationary, or carried through the streets.

The aforementioned law of the Siete Partidas, that gives us our first definite information concerning religious plays, and another that follows closely upon it, ${ }^{1}$ furnish interesting facts regarding certain games that were in vogue about the middle of the thirteenth century. These were called juegos de escarnios and were attended by so many abuses that ecclesiastical officers and judges were ordered to suppress them. The games were held in churches and elsewhere, and were open to the public. Members of the clergy and laymen took part in them, the participants wore clerical garb and mimicry of the clergy was a prominent feature.

Later Spanish documents that are more specific lead us to believe that these games were related to the New Year revels held by the sub-deacons in cathedrals and collegiate churches under the name of Feast of Fools, and to the celebrations on the days of St. Stephen, St. John the Evangelist and the Holy Innocents by the deacons, priests and choir-boys. Documents of the fifteenth century give considerable information concerning the mock ceremony of the Boy Bishop or Obispillo at Gerona and Lérida, and we have a fairly complete account of this practice at Seville in the first half of the sixteenth century. One of the commonest features on these occasions was the farcing of certain portions of the office or mass. This consisted in the addition of a trope and of a few words, at first in Latin, and later in the vernacular. Such a combination was called farsia, farsura, epistola farcita or farsa, and the later use of this word to designate a comic scene indicates the character that it must have early assumed. Church Councils and Cathedral Chapters protested time and again against the ludi theatrales, larvae, monstra, turpia carmina and derisorii

'Part i, tít. vi, ley 36. 
sermones that were introduced as a part of these post-Christmas revels, but the inferior clergy cheerfully risked a fine for the pleasure of conducting the services once during the year, and the onlookers crowded the churches to see the fun. It is difficult to determine the influence of these festivals upon the drama, but one is tempted to ascribe to them some of the comic scenes that enlivened the early Christmas plays. ${ }^{1}$

The whole question of the origin of comedy in Spain is beset with difficulties. We know that the reign of the Roman mime did not come to an end with the fall of Rome, nor was his voice silenced by the vigorous protests of Church Fathers and Councils throughout the Middle Ages. ${ }^{2}$ The frequent references to him, and to the joculator, his twin-brother, are ample proof of his success as an entertainer. The Siete Partidas frequently mention remedadores, bufones and juglares, and we know that the household of Lucas de Iranzo included locos as well as musicians and dancers. ${ }^{3}$ Their presence was indispensable at weddings and festivals, and their accomplishments consisted in singing, playing musical instruments, exhibiting trained animals, acrobatic feats and buffooneries. A study of the early sixteenth-century plays furnishes some information respecting the repertory of these entertainers, but the extent of their contribution to the development of comedy cannot be determined.

There is abundant documentary evidence that the Royal Entry was celebrated by municipalities with processions and games of various kinds. We are told, for example, that when Alphonso XI made his entry into Seville in 1327 , there were

${ }^{1}$ For the ceremony of the Obispillo, see José Sánchez-Arjona, El teatro en Sevilla en los siglos XVI y XVII, Madrid, I887; and J. P. W. Crawford, $A$ Note on the Boy Bishop in Spain, Romanic Review, vol. xii, 1921 .

'E. Faral, Les Jongleurs en France au Moyen Age, Bibliothèque de l'Ecole des Hautes Etudes, vol. 187, Paris, 1910, and A. Bonilla y San Martin, Las Bacantes, o del origen del teatro, Madrid 1921, pp. 49-6r.

${ }^{3}$ Memorial histórico español, vol. viii, p. 47. 
masquerades (máscaras), representaciones, triumphal arches and knightly games. ${ }^{1}$ By representaciones were doubtless meant pageants, without action or dialogue. The initiative for these pageants rested with the municipalities, assisted by the guilds and brotherhoods.

A procession held at Saragossa in 1399, in honor of the coronation of Martin $I$, included a pageant representing $a_{4}$ castle bearing four sirens and many angels who "sang sweetly", and also a child dressed in white who represented the King." During the banquet that followed, a masquerade was performed which required considerable scenery, and indicates the tendency toward symbolism in such entertainments. In the procession held in the same city in 1414 to celebrate the coronation of Ferdinand of Antequera, a mock siege was represented, followed by a castle-pageant bearing on the tower four maidens symbolizing, Justice, Truth, Peace and Mercy, who sang in praise of the virtues of the King, represented by a child seated in the centre. ${ }^{3}$ This pageant is of especial interest because of its early use of allegory. The songs employed on this occasion were for a long time incorrectly ascribed to Enrique de Villena."

The Cronica del Condestable Miguel Lucas de Iranzo, covering the period from I459 to I47I, gives an excellent idea of the diversions of a nobleman of his time. After a dinner given to celebrate his marriage in 1461 , a group of gentlemen of his household entered, wearing masks and representing that they had been freed from captivity in order to attend the fiesta, and executed a pantomimic dance. More interesting is the masquerade performed before Lucas de Iranzo two days after Christmas in the year 1463. A number of knights, dressed in Moorish costume and representing themselves as

'Schack, op. cit., vol. i, p. 225.

'M. Milá y Fontanals, Origenes del teatro catalán, Barcelona, I895, pp. $236-38$.

${ }^{3}$ Schack, op. cit., vol. i, pp. 235-236.

4A. Morel-Fatio, Romania, vol. xxvi, p. I27. 
the escort of the King of Morocco, challenge the Christian knights to a juego de cañas, promising to renounce their Prophet in the event of defeat. We can readily surmise the outcome of the combat, which results in the complete rout of the Moors and the pouring of a bucketful of water on the King's head as a symbol of baptism.

Among the works of Gómez Manrique, we have the text of a simple masquerade written to celebrate the birth of his nephew. Here Justice, Prudence, Temperance, Courage, Faith, Hope and Charity recite stanzas, endowing the child with the virtues they represent. More elaborate is the masquerade composed by Gómez Manrique in 1467 at the command of the Infanta Isabel, to celebrate the fourteenth birthday of her brother Alphonso, who had been proclaimed King of Castile in 1465 as a result of the rebellion against Henry IV. After a laudatory introduction in which it is explained that the Muses have come to honor the young King, nine ladies of the Court, including the Infanta Isabel, prophesy happiness, liberality, power and success in love for the youth who was to die the following year without having occupied the throne.

The dialogues and debates which appear in the Cancionero de Baena, and more particularly in the Cancionero de Hernando del Castillo are non-dramatic, but a few of these themes were contributing factors in the creation of the courtly drama in the early part of the sixteenth century. ${ }^{1}$ The requesta de amores, for example, was dramatized by Encina and many of his successors, and the well-known débat of the seasons is found in two plays of Gil Vicente. The best of the dialogues written in Spain in the fifteenth century is the delightful Dialogo entre el Amor y un viejo by Rodrigo Cota de Maguaque. An old man, disillusioned with life's pleasures, has retired to a lonely spot where he hopes to find rest for his tortured spirit. When Cupid intrudes upon his privacy, the

${ }^{1}$ The dramatic nature of the earlier disputas is discussed by A. Bonilla y San Martin, Las Bacantes, o del origen del teatro, pp. 62-69. 
old man angrily bids him to withdraw, for he has already brought him untold misery. The tiny god humbly pleads his cause, alleging all the blessings that he confers upon men. The old man is deceived by these specious arguments and offers to become once more the servant of Love, whereupon Cupid brutally ridicules his pretensions, makes sport of his infirmities and promises him still greater suffering. While not intended to be performed, these stanzas have real dramatic quality, and are, furthermore, of interest because they have many points of similarity with Encina's Representacion del Amor and Egloga de Cristino y Febea. 


\section{CHAPTER II}

\section{Juan Del Encina}

Is his famous Loa de la comedia, ${ }^{1}$ in which Agustín de Rojas outlines the early history of the drama, the honor of being the first Spanish dramatist is ascribed to Juan del Encina. While this statement may not be literally true, we must concede to Encina the title of founder of the Spanish drama. The fact that no less than eight editions of his Cancionero appeared between 1496 and 1516 , is pronf that his plays were read and admired, and there is no question that his religious and pastoral dramas were accepted as models by other poets for half a century.

Documents recently discovered throw considerable light upon his family and his own early years. He was born in the year 1468 at Salamanca. His father, Juan de Fermoselle, was a shoemaker who, in spite of his humble circumstances, succeeded in providing his sons with a good education. One of these, Diego, became a Master of Arts and Professor of Music at the University of Salamanca; Miguel was ordained a priest and occupied various posts in the Cathedral of Salamanca; Pedro was also a cleric and another son, Antonio, was an attorney. Records show that our poet, Juan de Fermoselle, was a choir boy in the Cathedral in 1484 , receiving instruction from Fernando de Torrijos. By 1490 he had discarded his father's surname and is mentioned as Chorister with the name of Encina.

He studied at the University of Salamanca, where he pro-

${ }^{1}$ Included in El viaje entretenido, Madrid, 1603, which may be read conveniently in the Nueva Biblioteca de Autores españoles, vol. xxi. 
bably obtained both his baccalaureate and licentiate, since he is mentioned with these degrees in later documents. We may accept his Aucto del repelon as a picture of student life, as he knew it, at Salamanca. It is likely that he there came under the influence of Lebrixa, to whose Gramatica castellana Encina was indebted in the composition of his own Arte de la poesia castellana. A considerable portion of his verse dates from his student days, since he states in the dedication of his Cancionero to Ferdinand and Isabella that his poems were composed between the age of fourteen and twenty-five. His interest in classical studies is attested by his paraphrase of Vergil's Eclogues, dedicated to the young Prince John in 1492.

While at the University, he won the favor of its Chancellor, Gutierre de Toledo, who was probably instrumental in securing for him a position in the service of his brother, Fadrique 'Alvarez de Toledo, Duke of Alba. He probably entered the latter's household in the autumn of the year 1492, and remained there, discharging the duties of musician and court poet, until at least the year 1498 .

His first two plays were probably presented on Christmas Eve, $1492,{ }^{1}$ in a hall or chapel of the Duke of Alba. The first, which serves merely as a prologue to the Christmas play that followed, is a sort of "disguising" which introduces two shepherds who extol the virtues of the Duke and Duchess, and discuss their own personal affairs. It appears that the protection offered to Encina by the Duke of Alba had aroused the enmity of less fortunate rivals. In this play, Juan, who seems to be Encina himself, complains that his verses are circulating in corrupt form, and promises an edition of his works that will silence his detractors. One of these rivals seems to have been the poet, Lucas Fernández, and Juan speaks with contempt of his pretensions to enter the service of the

${ }^{1}$ Eugen Kohler in his Sieben spanische dramatische Eklogen, p. 20, argues that the traditional date of 1492 is open to question since the passage in the Loa de la comedia does not necessarily assign that year as the date of representation of Encina's first play. 
Duke of Alba. The pastoral form of this "disguising" was probably suggested by Vergil's Eclogues, and to these Encina was also indebted for his use of the word egloga to designate his plays. In order to introduce a little local colour, which might amuse his patrons, the shepherds in this scene speak the rude dialect of the country-folk in the vicinity of Salamanca, ${ }^{1}$ and this, through his influence, became the rule in later pastoral and religious plays.

The play that followed is a primitive example of the Officium Pastorum, and represents a blending of the Christmas liturgy and the Gospels. The interlocutors are four shepherds, Matthew, Mark, Luke and John, who have just heard the announcement of Christ's birth. In simple language, they discuss this fulfillment of the prophecies, each of the shepherds employing the phraseology of the corresponding Gospel. Singing and dancing, they set out to worship the Child, and the play ends with a charming carol. While this composition has little dramatic value, it is attractive by reason of its simplicity and the spirit of devotion that pervades it.

The Representacion a la muy bendita pasion y muerte de muestro precioso Redentor was presented in the chapel of the Duke of Alba on Good Friday of the year I493 or 1494 . Two hermits, who have learned of the Crucifixion of Jesus, seek the sepulchre and meet Veronica who relates to them the Saviour's Passion, according to the Gospel accounts, and shows them the cloth on which Christ's features were imprinted. They kneel in prayer, and an angel appears who explains in simple language the doctrine of the Resurrection. A villancico, in which happiness is promised to the afflicted, concludes the play.

The Representacion a la santisima resurrecion de Cristo, presented in the chapel at Easter, I493 or 1494, is a primitive form of the Officium Peregrinorum. As Joseph of Arimathaea kneels before the open sepulchre, Mary Magdalene re-

1 Lamano y Beneite, Et dialecto vulgar salmantino, Salamanca, 1915, p. 9. 
lates to him that Jesus had appeared to her in the figure of a gardener. Luke and Cleopas then enter and declare that the Saviour had appeared to them on the road to Emmaus and had even broken bread with them. These faithful disciples explain devoutly the significance of the Resurrection for mankind, and an angel bids them be of good cheer since Christ has risen from the dead. Encina refrains from presenting Jesus in these plays, and, in consequence, the incidents of the Passion and the Resurrection are merely narrated. In the latter composition, there is a considerable didactic element which was to become a more prominent feature in the plays of Lucas Fernández and Diego Sánchez de Badajoz.

The two Carnival eclogues were performed at the palace of the Duke of Alba on Shrove Tuesday, probably of the year $1494 .^{1}$ The first, which merely serves as a prologue to the second, is a colloquy in pastoral style between two shepherds, Bras and Beneito, in which they extol the virtues of the Duke, and lament his rumored departure to serve in the army against France. Another shepherd announces that peace $^{2}$ has been signed between the two countries, and the play ends with a villancico.

The second Carnival eclogue presents four shepherds, who are testing the capacity of their stomachs in anticipation of the forty days of fasting that begin on the morrow. One of the shepherds gives a humorous account of the defeat of Carnival by Lent, which recalls the thirteenth-century Bataille de karesme et de charnage and also La pelea que ovo don Carnal con la Quaresma of Juan Ruiz. This little farce ends with a villancico, which has much in common with some of the songs of the Goliards, and is unsurpassed among Encina's lyrics.

The Egloga representada" en requesta de amores, performed

${ }^{1}$ For a discussion of the date, see Kohler, op. cit., pp. 24-25.

${ }^{2}$ The treaty referred to was negotiated by Ferdinand and Charles VIII in September, 1493. 
in all probability at Christmas, 1494 , is conceived in an entirely different spirit from the plays alreadly examined. While the pastoral element in the aforementioned plays is derived from a desire to give a realistic representation of everyday life, the theme of the requesta de amores is distinctly aristocratic.

The shepherd Mingo courts the shepherdess Pascuala and urges her to accept his love. His plea is interrupted by the appearance of a knight who soon proves to be a rival. He sneers at Mingo's pretensions; the two suitors abuse one another, and finally Mingo suggests that the shepherdess choose between them. The knight agrees to this, and Pascuala expresses her preference for him, on condition that he become a shepherd. The courtier gladly accepts the terms, offers Mingo his friendship, and the play ends with a song.

The requesta de amores theme, which is identical with the pastourelle, is found occasionally in the courtly literature of the fifteenth and early sixteenth centuries. ${ }^{1}$ Encina himself composed a sort of contrasto between a shepherd and knight, published in the Cancionero musical. The thirteenth-century Jeu de Robin et Marion of Adam de la Halle represents the same sort of transition from lyric poetry to drama as we find in this eclogue of Encina.

The second Egloga en requesta de amores, with the same characters as the above, was performed after an interval of a year, probably at Christmas, I495, and consists of two scenes. In a brief prologue, the timid Mingo offers to the Duke and Duchess his collected works, (which were published in 1496), and in rather awkward fashion we are informed that a year has passed since the incidents described in the preceding play. The knight, now known as Gil, wearies of pastoral life, and longs to return to the palace with Pascuala. The latter dons the robes of a lady and amazes Mingo and his wife, Menga, by her beauty, which Mingo ascribes to the power of Love.

\footnotetext{
${ }^{1} \mathrm{R}$. Menéndez Pidal discusses the early popular serranillas in his essay entitled La primitiva poesía lírica española, published in Estudios literarios, Madrid, 1920.
} 
Gil urges Mingo to accompany them, but the shepherd hesitates, alleging his ignorance of courtly manners and his delight in the simple joys of pastoral life, which he describes in verses that reveal true poetic feeling. The idea of becoming a gentleman, however, tickles his vanity, and with keen satisfaction he puts on his best clothes and adopts the airs of a courtier. The play ends with a song in praise of all-powerful Love. Here the well-known débat on the relative advantages of city and country life is combined with the theme of the power of Love, frequently treated in the fifteenth-century cancioneros and ultimately derived from Ovid's Ars amatoria.

These two compositions cannot be considered as popular in any sense of the word. We are not dealing here with real shepherds, but with shepherds portrayed in accordance with an aristocratic literary tradition. We have abundant evidence of the contempt of the cortesano for the villano which was so frequently expressed in the courtly literature of the day, and the dramatic basis of these plays, performed before an audience of gentlefolk, lies in the portrayal of the shortcomings of rustics in trying to meet aristocracy on its own level. The situation also gave the author an opportunity to satirize pleasantly some of the affectations in manners and language imposed by fashion.

In addition to the eight plays already mentioned, Encina's Cancionero, which first apeared at Salamanca in 1496 with a dedication to Ferdinand and Isabella, contained a number of other compositions. His Arte de la poesia castellana considers the theory and practice of verse-writing as understood at the close of the fifteenth century by the court poets. In his paraphrase of Vergil's Eclogues, he uses freely his original in order to make it applicable to the historical events of his own time. He does not excel a number of his contemporaries in long allegorical compositions and religious verse, but he had a special aptitude for vers de société which deserve high praise for their musical qualities rather than for their content. $\mathrm{He}$ is at his best in pastoral lyrics which often have the true savor of popular poetry. 
The Representacion del Amor, first published in the 1507 edition of his Cancionero, has an especial interest because of its performance at Salamanca or Alba de Tormes in 1497 before his patron, Prince John of Castile, and his bride, Margarita of Austria, whose marriage had been solemnized at Burgos on April second of that year. To celebrate this happy occasion, Encina chose the theme of the omnipotence of Love, treated in burlesque fashion, with a shepherd as the victim of the tiny god's shaft. Cupid enters, armed with bow and arrows, asserting his power over all mortals in terms that closely resemble the boasting loquaciousness of Amor in Rodrigo Cota's Dialogo. He meets the shepherd Pelayo, who failing to recognize him, asks by whose permission he hunts on forbidden territory. Pelayo refuses to heed Cupid's warning and is laid low by an arrow. The shepherd, Juanillo, finds Peiayo suffering keenly from his wound, the nature of which the unfortunate victim is unable to understand, even when Juanillo explains that it was caused by Amor. But to Pelayo, the word Amor suggests only morder or mortaja; he is unacquainted with courtly terms. A knight, who joins them, adds his testimony to the anguish caused by Love, who tortures, but does not kill. In the charming song, "Ojos garzos ha la niña", with which the play ends, the poet probably referred to the newly-married Princess, ${ }^{1}$ who was to become a widow a few months later.

Another Christmas play, often styled Egloga de las grandes lluvias, was performed on Christmas Eve, 1498, probably at the palace of the Duke of Alba. Four shepherds, seated around a fire, talk of the heavy rainfall and floods that have caused severe losses. They begin to play pares and nones, but the game is interrupted by the angel's song, announcing the

\footnotetext{
${ }^{1}$ Carolina Michaelis de Vasconcellos, Notulas sobre cantares $e$ vilhaneicos peninsulares $e$ a respeito de Juan del Enzina, Revista de Filología Española, vol. v, 1918, pp. 346-50. This song, which is not included in the Spanish Academy edition, may be read conveniently in Menéndez y Pelayo's Antología de poetas líricos, vol. iv, p. 373 .
} 
birth of Christ. They do not understand at first; one of the shepherds confuses the word Salvador with saludador. Finally they take their simple gifts and set out to visit the manger. Here we have a crude attempt at realism which almost completely overshadows the sacred element.

Reference is made in the play to the post of choir-master in the Cathedral which had become vacant. The shepherds discuss who the fortunate appointee will be, and when Anton suggests Juan, Miguellejo objects that they will probably prefer some outsider. It has recently been discovered that the post referred to was that of choir-master left vacant by the death of Fernando de Torrijos in 1498, and that Encina and Lucas Fernández were numbered among those who solicited the appointment. Fernández was able to count on the support of influential friends and relatives, and the question was finally settled by a Commission of the Chapter, which decided that the salary attached to the post be divided among three choristers, one of whom was Lucas Fernández. Encina's disappointment over his failure to secure the place, coupled with his feeling that his services were not adequately appreciated by his patron, led him to shake the dust of Salamanca from lis feet.

An anonymous and undated Christmas play, entitled Egloga interlocutoria, has also been attributed to Encina by several critics. Like Encina's second Christmas eclogue, with which it has a number of verbal similarities, this play presents four shepherds who have heard the news of Christ's birth. Unlike the former play, however, the shepherds show little interest in this announcement and are completely absorbed by their petty quarrels and their desire for amusement. They gamble for a while, and the play ends quite abruptly with a eulogy in coplas de arte mayor of the Duke and Duchess. It has been noted ${ }^{1}$ that this play has the same incidents as the Egloga de las grandes lluvias, arranged in the reverse order.

${ }^{1} \mathrm{R}$. E. House, $A$ study of Encina and the Egloga interlocutorio, Romanic Review, vol. vii, I916, pp. 458-69. 
It shows carelessness in workmanship, and is far inferior to any play printed with Encina's name. It has been argued that it was written in haste by Encina for a Christmas celebration; that its author did not intend to publish it, and that its preservation was due to the actors who wrote it out from memory. Whether this be true, or whether someone unscrupulously pilfered from Encina's plays after the latter had left the service of the Duke of Alba, is difficult to determine.

In the plays already examined, Encina shows no influence of foreign models. His indebtedness to Vergil is limited to his use of the word eclogue to designate plays where shepherds appear, and to the pastoral form in the prologues to the first Christmas and first Carnival plays. The religious compositions represented an attempt to adapt the liturgical drama to the requirements of a small audience in a private home, while the two Eglogas en requesta de amores and the Representacion del Amor dramatized themes found in the lyric poetry of his time.

We do not know the exact date of Encina's first visit to Italy. He may have been one of the thousands of pilgrims who were attracted to the Holy City by the Jubilee of 1500 . In a document dated September I5, I502, by virtue of which he received an appointment from the Pope to a benefice at Salamanca, he is described as "Clerigo salmantino, bachiller, familiar de S. S. y residente en la curia romana". Neither do we know whether he assumed these new duties at once, or whether he tarried for some time at Rome. It is evident, however, that he retained the Pope's friendship, for in 1509 he received an appointment from the Papal Nuncio to an archdeaconship and canonship at Malaga, and took possession of these offices at the beginning of the year I5IO. He was evidently regarded as an important personage, since he was employed by the Chapter on various missions. However, his relations with the Chapter were somewhat strained, chiefly because he had not taken Orders, and also because of frequent absences from his post of duty. 
On May 17, 1512, he obtained permission to go to Rome, and probably remained there until July of the following year. It is difficult to overestimate the inspiration that Encina must have received as a result of his visit to the center of artistic and literary activity at the culminating period of the Renaissance. Toward the end of the year I5II, Raphael's frescoes in the Camera della Segnatura were completed, and about a year later Michael Angelo's frescoes on the ceiling of the Sistine Chapel were unveiled. Encina was in Rome when Julius II died and when the son of Lorenzo the Magnificent was elected to the Papacy on March II, I5I3. He must have been in the crowd that witnessed the magnificent ceremony of taking possession of the Lateran on April eleventh, or perhaps took part in the procession as a member of the Papal choir. We do not know when he secured the Pope's favor, but the fact that Leo $\mathrm{X}$ aided him subsequently proves that he had a liking for the poet. It is probable that Encina obtained the Pope's protection because of his accomplishments as a musician, for it is well known that Leo $\mathrm{X}$ had a predilection for music, and drew to his court the best musicians of Italy and from abroad.

We have documentary evidence that he had returned to Malaga by August, 15I3, and that on March 3I, 15I4, he announced his intention of returning to Rome. The objections of the Chapter were overruled by a Bull of Leo X who continued to extend to him his favour, and shortly after his return to Spain, he received on May 21, 1516 , an order from the Bishop of Malaga to appear at Valladolid under penalty of excommunication. We do not know the reason for this summons, but apparently he was still supported by the Pope, for he was appointed to the lucrative post of "subcolector de espolios de la Cámara Apostólica" which permitted him to absent himself from his duties at Malaga. Finally on February 21,1519 , he resigned his position at Malaga and received in exchange a benefice at Moron. It seems that he never assumed the duties of this latter position, for he was 
appointed prior of the church of Leon by the Pope in March of the same year and took possession of that post by proxy, since he was still residing in Rome.

He had now passed his fiftieth year and he determined to cast aside worldly affairs, take Orders and make a pilgrimage to the Holy Land. He gives an account of this journey in his Tribagia, o via sacra de Hierusalem, an insipid composition in coplas de arte mayor, published at Rome after his return in I52I. (?). Here he describes the profound impression made upon him by the sacred places he visited and relates that he spent three nights in prayer at the Holy Sepulchre and said his first mass on Mount Zion.

Returning to Rome in the autumn of 1520 , he probably remained there until 1523 when his name first appears on the minutes of the Chapter of the church of Leon. Documents recently discovered show that he was awarded exceptional honors by the Chapter and that he fulfilled his duties as prior from October 2, 1526 until October 2, 1528. His death occurred between January 27, I 529 and January 10, 1530, and there is good reason to believe that he was buried at Salamanca.

This brief sketch of Encina's later years gives abundant evidence of the fascination exercised by Italy upon his restless, inquiring mind. The intense literary activity of that country must have awakened his interest, particularly the recent innovations in dramatic literature with which he became familiar. The Italian versions of Plautus and Terence which had appeared at Ferrara, Mantua, Rome, Florence and other cities must have attracted his attention, but he was particularly interested in a new form of pastoral drama, compared with which his own pastoral plays must have seemed crude. Poliziano's Orfeo was but the first of a long series of mythological and allegorical plays, and pastoral eclogues, recited on festival occasions at the great courts, were in fashion. We shall see that three of the plays composed by Encina after his first visit to Rome, namely, the Egloga de tres pastores, Egloga 
de Cristino y Febea and Egloga de Placida y Vitoriano, show the influence of Italian literature, and that one of them is directly derived from an Italian eclogue.

Two new plays appeared in the edition of Encina's Cancionero published at Salamanca in 1509 , the Egloga de tres pastores and Aucto del Repelon. The first of these, as its name indicates, is a pastoral composition, but it has little in common with the poet's earlier plays of shepherds. Fileno is driven almost to the point of madness by the indifference of his sweetheart, Cefira. Unable to secure sympathy from Zambardo who falls asleep over the recital of his anguish, he breaks out in a furious invective against the god of Love, and then confides in his friend Cardonio the cause of his suffering. Cardonio counsels moderation, protesting that his friend blames all women for the cruelty of one. Then follows a sort of contrasto, in which Fileno attacks women with the bitterness shown by Boccaccio in the Corbaccio, to which he himself refers, while Cardonio eulogizes women and their virtues. As soon as Fileno is left alone, he curses Cefira for the suffering she has caused him, takes leave of his flock, calls upon death to release him from his pain, and stabs himself. When Cardonio returns, he finds him lying on the ground, his body stained with blood. He mourns tenderly the death of his friend, calls Zambardo to aid in the burial and inscribes an epitaph over Fileno's tomb.

The play is composed in eighty-eight octaves in coplas de arte mayor, Encina's first and only attempt to use this meter for dramatic composition. It shows more power and seriousness of purpose than its author had hitherto displayed. Love is here no trivial matter, as in the two eclogues en requesta de amores, but a consuming passion that drives the hapless Fileno to his death. It is the first tragedy of the Spanish theatre, and occupies the same position in the drama as the Carcel de Amor of Diego de San Pedro in Spanish fiction. Juan de Valdés spoke approvingly of it in his Dialogo de la lengua, although he expressed a preference for the Egloga de Placida y Vitoriano. 
The Egloga de tres pastores shows a great advance in dramatic art over earlier Spanish plays, but at least one episode is a reminiscence of his own Christmas eclogues, namely, the opening scene in which Zambardo falls asleep while Fileno is mourning his unrequited love for Cefira. It is interesting to find the burlesque element appearing in the first serious Spanish play of secular character. The dispute between Fileno and Cardonio concerning the relative virtues and imperfections of women is the first example of the dramatic treatment of a theme that occupied the attention of the poets, misogynists and philogynists, of the fifteenth and sixteenth centuries, and which occurs later in the Farsa del matrimonio of Diego Sánchez de Badajoz, the Comedia Tibalda of Per Alvarez de Ayllón and other plays.

The latter part of this play, dealing with the suicide and burial of Fileno, is a close adaptation of the second eclogue of the Italian poet, Antonio Tebaldeo. Born at Ferrara in I463, Tebaldeo served for a time as preceptor in Italian poetry to the Princess Isabella d'Este, and later acted as secretary to Lucrezia Borgia. He went to Rome about the year I5I3 and there became intimate with the leading men of letters of his time. When the Imperial troops sacked the Holy City in I527, he lost all his property, for which throughout his life he cherished resentment against Charles V. He died in the year I537. His early verses were published in 1499 without the poet's knowledge by his cousin Jacopo Tebaldeo. These consist of four pastoral eclogues, epistles in terza rima and about three hundred sonnets, which are characterized by exaggeration and abuse of rhetorical figures to gain an unexpected effect. His verses were admired by the generation that found delight in the affectations of Serafino Aquilano and Benedetto Gareth (or Cariteo) and he shared with the former a revival in popularity, both at home and abroad, toward the middle of the sixteenth century when préciosité again became the fashion.

His second eclogue consists of two hundred and fifty-one 
lines in terza rima. Here the lovelorn Damone refuses the proffered sympathy of his friend Tirsi, explaining that he wishes to bear his burden of grief alone. When Tirsi withdraws, the enamoured shepherd declares that he is ready for death since Amarilli turns a deaf ear to his wooing. As he stabs himself, he bids a tender farewell to his flock, now left without a shepherd, and with his last breath pardons the maiden for her cruelty. When Tirsi returns, he sees his friend lying in a pool of blood with a dagger in his heart. He tenderly mourns his death, prepares the body for burial and composes an epitaph for his tomb.

It is of interest to note the changes made by Encina in adapting this eclogue. He expanded the two hundred and fifty-one lines of the Italian composition into a play which occupies thirty-nine pages in the edition of the Spanish Academy. He introduced a third character, the shepherd Zambardo, probably because it offered him an opportunity for a bit of burlesque, and the débat regarding the virtues and imperfections of women is also original. He closely followed his original in describing Fileno's death and burial, and transformed into a real play what was little more than a literary exercise.

With respect to the date, we can only say with certainty that the Egloga de tres pastores was written after I499, the year of publication of Tebaldeo's eclogue. Since it was not included in the 1507 edition of the Cancionero, we are perhaps justified in assuming that it was written between 1507 and 1509 . We have no evidence in regard to the place of its performance.

The Aucto del repelon, likewise first published in the 1509 edition of the Cancionero, is the only play of Encina that deals entirely with farcial material. It treats of the hazing of a couple of shepherds by a group of students, a conflict between town and gown that was common enough at the Universities during the Middle Ages and Renaissance. In a sense it may be regarded as a precursor of the pasos of 
Lope de Rueda, with the important difference that it seems to be a separate entity, and not merely a part of a longer play. Its many allusions to academic customs lead us to believe that it was performed at Salamanca before an audience of students. We have no means of determining whether this is an early play or whether on one occasion, after his return from Italy, the poet forsook Arcadia to give us a bit of actual life. ${ }^{1}$

The Egloga de Cristino y Febea presents, with pastoral setting, the conflict between asceticism and worldliness, and the triumph of the flesh over the spirit. The shepherd Cristind is weary of life with its bitter disappointments and disillusions, and determines to do penance for his sins. In spite of the protests of his friend Justino, he departs to don the garb of a hermit. Cupid is furious on learning of his disloyalty and bids the nymph Febea bring the shepherd to his senses. A brief conversation with Febea suffices to prove to Cristino that the Church is not his vocation, and he promises Cupid to discard his cassock provided that he be granted the love of Febea. Cupid agrees to these terms, but warns him not to repeat his experiment. By this time, Cristino realizes that a hermitage is only suitable for centenarians, and that, after all, there are more good shepherds, or courtiers, in the world than friars.

This play was not published in any edition of Encina's Cancionero, and the unique copy in which it has been preserved bears no date. We can only say with certainty that it was written before the publication in 1514 of Lucas Fernández's Farsa o cuasi comedia del soldado, which contains a reference to it. It is evident that it contains reminiscences of Rodrigo Cota's Dialogo entre el Amor y un viejo, which must be regarded as the source of the poet's inspiration. At the same time, the anti-clerical tone and the figure of the nymph seem to be due to Encina's acquaintance with Italian literature.

We have documentary evidence that a composition of

${ }^{1}$ Kohler, op. cit., pp. II9-2I, presents arguments for Italian influence on this play, which seem to me unconvincing. 
Encina was performed at Rome on January 6, 1513 at the house of Cardinal Arborea before the Spanish Ambassador and an audience composed of distinguished members of the Spanish colony, and demi-mondaines, and this play has been generally identified as the Egloga de Placida y Vitoriano." The unique original that is extant bears neither date nor place of publication, and nothing is known of an edition published at Rome in 1514 except that it was mentioned by Moratín. It is much longer and shows a more complex construction of plot than any of its predecessors. It opens with a prologue recited by a shepherd, who addressing the compaña nobre and especially nuestro amo (probably Cardinal Arborea), gives an outline of the plot and asks for attention. The eclogue or comedy (both terms are used) consists of thirteen scenes, two of which, the sixth and tenth, are of the nature of pasos and were introduced for comic relief. A villancico is sung at the close of the sixth scene.

Plácida mourns because she believes herself abandoned by her lover Vitoriano. His absence makes her long for death, and at the same time she curses him for his treachery. In her anguish, she calls for her recreant lover and determines to flee to the mountains and forests where the wild beasts, the springs and rivers will have pity upon her grief. After she withdraws, Vitoriano appears, complaining that he has been unable to escape from the bonds that unite him to his mistress since absence has only increased his love for her. He seeks the counsel of his friend Suplicio, who urges him to forget the old love by taking up a new one, and suggests that he pay court to the fair Flugencia. Vitoriano accedes to this with some reluctance, and Suplicio promises to arrange the meeting.

${ }^{1}$ Senhora Michaelis de Vasconcellos, Revista de filología española, vol. v, pp. $362-63$, believes that the play of Encina referred to in a letter to Francesco Gonzaga, Marquis of Mantua, was the Representacion del Amor. This letter states that the play dealt with "le forze et accidenti di amore", which applies as well to the Egloga de Placida y Vitoriano as to the Representacion del Amor. 
In the next scene, Vitoriano greets Flugencia, declaring himself a slave of her beauty. She makes sport of his protestations, but coquettishly gives him reason to hope that his desires will be gratified. The scene is skilfully represented and shows Encina at his best as a dramatist.

The following scene, derived from the Celestina, has little connection with the rest of the play. Flugencia meets and gossips with the comadre Eritea, an infamous hag, who is skilled in magic love-potions, abortions and other disgraceful practices. They take leave of one another and Suplicio and Vitoriano reappear. Vitoriano tells Suplicio that Flugencia can never make him forget his love for Plácida and that he would rather die a thousand deaths than break faith with her. He goes off in search of Plácida, leaving Suplicio alone, who bitterly reproaches Cupid for having wrought this transformation in his friend. Vitoriano returns in a state of great anguish, for a shepherd has told him that Plácida had been seen seeking some lonely spot and lamenting the infidelity of her lover. He determines to die since he has been guilty of so great cruelty. While Suplicio is questioning the shepherd, Vitoriano slips away.

The dialogue that follows between the shepherds Gil and Pascual is in the nature of an interlude and resembles the rude representation of shepherds found in Encina's Christmas plays. The burlesque purpose of the scene is evident. They talk about the strange conduct of Plácida and Vitoriano, and agree that love often makes city folk ridiculous. They play a game of dice and then withdraw, singing a villancico.

Plácida appears, lamenting her cruel fate and desirous only of death since she has lost the love of Vitoriano. With bitter reproaches that recall those of the abandoned Dido, she plunges into her heart a dagger left behind by Vitoriano, and calls upon Cupid to receive her sacrifice. Vitoriano enters, mourning the absence of his sweetheart, but Echo alone answers his laments. He comes upon the corpse of Plácida, becomes deathly pale and is overwhelmed with grief when he 
learns that she had ended her days with his own dagger. $\mathrm{He}$ desires to take his life, but Suplicio warns him that in doing so, he would lose his soul as well as his body, and only consents to leave him alone on the promise that he will do himself no injury.

This scene is followed by the Vigilia de la enamorada muerta, a sacrilegious parody of the Officium Defunctorum in which the god Cupid is invoked. We need not wonder that the play was not printed in any edition of the Cancionero, nor that it was placed in the Index of 1559 . The fact that parodies of this kind were composed by a number of Encina's contemporaries does not mitigate the offense, but serves to explain it. Probably the most famous example is found in the Liciones de Job of Garci Sánchez de Badajoz, and a similar irreligious spirit animates the Siete gozos de amor of Rodríguez del Padrón, the Diez mandamientos de amor and Pater Noster de las mujeres of Mossén Gaçull, and other compositions included in the Cancionero general de Hernando del Castillo.

The need for comic relief explains the following scene, in which the two shepherds express doubts concerning Suplicio's good faith and show little interest when he tells them that Plácida has put an end to her life. They even refuse to aid in her burial until they have had a nap. Vitoriano then appears, dagger in hand. He desires to die without confession, and commends his soul to Venus. At that moment Venus presents herself and stays his hand, assuring him that Plácida is not really dead and offering to restore her to her lover if he will have faith. Plácida is resuscitated through the good offices of Mercury and the lovers are re-united. The play ends with singing and dancing. Following the text are ten canciones which are not the work of Encina, and also a farced version of the Nunc Dimittis by the dramatist Hernán López de Yanguas.

While this play has rather a series of disconnected episodes than a well-knit plot, it shows a decided advance over Encina's 
earlier compositions, and some of the new elements undoubtedly have an Italian source. The dénouement brought about by the intervention of a classical goddess is particularly characteristic of the Italian pastoral drama, which frequently defied all laws of probability. At the same time, one scene derived from the Celestina shows that he had not lost contact with the literature of his own country, and the burlesque scenes in which shepherds serve as a foil to the extravagance of the protagonists, recall the poet's own eclogues en requesta de amores.

The measures used by Encina, chiefly octosyllabic verses of seven, eight, nine and ten-line strophes, together with décimas, double redondillas, quintillas and coplas de arte mayor give to his plays a lyrical quality. It is also noteworthy that all of his plays, with the exception of the introduction to the first Christmas eclogue, the Egloga de las grandes lluvias and the Egloga de tres pastores, conclude with a villancico or cantorcillo, usually accompanied by a dance. The second Egloga en requesta de amores and the Egloga de Placida y Vitoriano are divided into two parts by a song. In the majority of cases the text is included, and the music of some of them has been preserved in the Cancionero musical. Most of these songs were sung by four persons, and this fact seems to have determined the number of characters in many of the early. plays. A fourth shepherd was introduced at the very end of the Aucto del repelon so that they might be able to "cantar dos por dos".

All forms of dramatic entertainment known in Spain of the fifteenth century found literary expression in the plays of Juan del Encina. The numerous editions of his Cancionero prove that his innovations awakened interest, and his influence upon the development of religious plays, festival representations and upon a long series of pastoral plays, cannot be questioned. His practice of combining recitation with song was continued by Lucas Fernández, Gil Vicente and other poets, and leads directly to the zarzuela in the time of Calderón de la Barca. 


\section{CHAPTER III}

\section{Religious Drama Before Lope De Rueda}

Further evidence of dramatic activity at Salamanca in Encina's time is found in the plays of Lucas Fernández, published in that city in $15 \mathrm{I} 4$. The title page of this edition refers to the author as a native of Salamanca. His uncle, Martín González de Catalapiedra, was Professor of Music at the University of Salamanca, and we have already seen that in 1498 Fernández was a rival of Encina for the post of choirmaster left vacant by the death of Fernando de Torrijos. $\mathrm{He}$ gives abundant evidence in his plays of his interest in music, and his acquaintance with the dramatic compositions of Encina is attested by several references. The plays of Fernández did not enjoy, apparently, the same success as those of his illustrious contemporary. So far as we know, he is not mentioned by any writer of his time, nor were his plays reprinted in his lifetime. In fact even his name was forgotten until Gallardo republished two of his plays in $1859,{ }^{1}$ and the edition of 1514 was not reprinted in full until 1867 .

Of his six extant plays, ${ }^{2}$ three are pastoral compositions, one is a Passion Play, and two, namely, the Egloga o farsa del nascimiento de nuestro Redemptor Jesucristo and the Auto o farsa del nascimiento de nuestro Señor Jesucristo, deal with the Nativity: The latter shows in its general plan a marked resemblance to Encina's Egloga de las grandes lluvias. Here we have a homely scene of every-day life which introduces the Nativity. The shepherd Pascual enters, com-

${ }^{1}$ El Criticón, nos. 4, 5, Madrid, 1859.

2 An entry in Fernando Colón's Registrum proves that the original edition contained seven plays. 
plaining of the cold and rain, and reciting a long list of all the good things he will eat at the first opportunity. He lights a fire and calls his companion Lloreinte. They began to play a game and Juan, another shepherd, appears and tells them of the song of the angels. Pascual and Lloreinte are at first incredulous and make sport of their companion, but finally are convinced that the strange light they had noticed in the heavens must have been a token of the birth of Christ. The shepherds talk in learned fashion of the Redemption and of the prophets who had foretold the coming of Christ, and they depart for the manger, singing in praise of the Child.

The Egloga o farsa del nascimiento de nuestro Redemptor Jesucristo serves as an introduction to the manger scene, although the latter is not represented. After a comic scene between two shepherds, the hermit Macario appears, who tries to explain to them that the Incarnation is at hand. They make sport of him, ridiculing him as a seller of indulgences, but another shepherd confirms Macario's message and announces to them that Christ has been born of a Virgin at Bethlehem. The two shepherds are still unconvinced, but when they hear a new proclamation of the angels, they kneel and sing "Et homo factus est". After many questionsquestions that would naturally suggest themselves to untutored minds, although to us they seem slightly irreverent-Macario explains the doctrines of the Incarnation and Redemption. The shepherds then depart for the manger with their simple gifts and the play ends with a villancico.

A reference in this latter play enables us to date it shortly after $1500,{ }^{1}$ and the former, which seems more primitive, may be ascribed to approximately the same period. In all probability they were performed in the Cathedral, or at least in its cloisters or portico, as was the practice at Toledo in I $51 \mathrm{I} .^{2}$ These plays have more dramatic interest than the Christmas

${ }^{1}$ Cañete, Teatro español del siglo XVI, Madrid, I885, pp. 3I-32.

${ }^{2}$ Cañete, op. cit., p. 80. 
plays of Encina. At the same time, the clerical element is more pronounced. Their purpose was to teach dogma rather than merely to make the audience familiar with the incidents of the Nativity, and this tendency is still further developed in the plays of Diego Sánchez de Badajoz. The function of the shepherds was to provide entertainment, and also by their feigned ignorance to provoke an explanation of theological doctrines.

Few men can be said to have created a national drama, yet the title of creator of the drama in Portugal belongs unquestionably to Gil Vicente. We have no evidence of the existence of dramatic performances in that country before his time and he himself tells us that his first play was also the first in Portugal. It is possible that he had in mind Court performances and that his statement does not exclude the possibility of the existence of religious representations, but if drama existed at all in Portugal in the fifteenth century, it was in an undeveloped state and his own extraordinary production was due almost entirely to his own originality and exceptional talents.

On June 7, 1502, Gil Vicente, dressed as a herdsman and accompanied by about thirty courtiers in similar costume, entered the apartment of Queen Maria in the Royal Palace of Lisbon and offered congratulations to her and to King Manuel and members of the royal family on the birth of Prince John. He tells of the rejoicing in Portugal and in the Spanish court over that happy event, and prophesies that the child will some day reign as John III and will inherit all the glories of the first and second kings of that name. His companions offer simple gifts, and then all withdraw.

This composition, called Monologo or Visitafao do vaqueiro, was a primitive type of masquerade, and was written in Castilian as a compliment to the Queen, who was the third daughter of Ferdinand and Isabella. A series of marriages between Spanish princesses and members of the Portuguese royal family had made the Spanish language fashionable at Lisbon where the Court, and court poets as well, were prac- 
tically bi-lingual. This explains why Vicente felt free to write plays in either language, as determined by the circumstances attending their performance, and also to assign Castilian parts to some characters and Portuguese to others, in the same play.

It appears that prior to I502, Gil Vicente was in the service of Dona Leonor, widow of John II, and that he had already written some verse. His position as court-entertainer seems to have been determined by the success of his first attempt at play-writing. Dona Leonor was so delighted that she requested the performance be repeated at the following Christmas matins, and from that time until 1536 , there were but few years that did not witness the performance under royal patronage of some auto or tragicomedia or farfa, of which Vicente was the author.

$\mathrm{He}$ deemed the little Monologue unsuited for performance at Christmas, and wrote a new play, the Auto pastoril castelhano, composed, as its title indicates, in Castilian, and this was likewise presented at the Royal Palace.

The transition from monologue to dialogue marks an advance in the poet's dramatic art; the action is developed by the introduction of six characters and the lyrical gift, in which he excelled, is seen to better advantage than in the earlier composition. The shepherd Bras makes sport of his companion Gil who prefers a quiet nook on the hillsides with his flock to the diversions in which his fellows take such delight. The beauty of the heavens has more charm for him than the prettiest shepherdess in the neighborhood. Their conversation is interrupted by the arrival of the newly-married Silvestre who recites at length the pedigree of his bride and the objects that constitute her dowry. Other shepherds join the group and they begin to play various games. They finally fall asleep and are awakened by the angel's song announcing the birth of the Redeemer. Gil explains to them that the Saviour is born, and they depart with their gifts for the manger, singing in praise of the Christ Child. 
The scene at the manger is tenderly portrayed. In their homely fashion, they pay homage to the Mother and Child, and take leave, singing a delightful little canfoneta. Gil explains to them that the prophecies of Solomon, Malachi and Micah have been fulfilled, and paraphrases a part of the Song of Songs. It is likely that Vicente was indebted to Encina for the general plan of the play, but he showed a deeper poetic feeling and a more refined and subtle understanding than his predecessor.

Dona Leonor was again pleased by the entertainment and requested another play for the following Twelfth Night. Her gracious enthusiasm must have been embarrassing to the poet, for the interval was too short to allow him to complete the play that he proposed to write for that occasion. Perhaps the scene in Fernández's Egloga o farsa del nascimiento, in which two shepherds make fun of the hermit Macario, suggested to him the introduction to this new play, the Auto dos Reis Magos. A shepherd named Gregorio has been seeking the Christ Child for thirteen days in accordance with the angel's summons. $\mathrm{He}$ is joined by another shepherd named Valerio, and they are met by a hermit who tells them that they will find the object of their search. But the hermit inspires in them no confidence. He rejoices that humble shepherds should leave their flocks to worship the Lord of Lords, but they ridicule him as a seller of indulgences and ask him whether it is a sin to sneeze or to pull off a cricket's leg. The hermit retains his dignity and declares that all those who do not dedicate themselves to the worship of the Christ Child stray from the true path. "But", they reply, "surely it would be a sin not to love the shepherdesses who are God's most perfect creatures". A gentleman appears who announces that three Kings have seen a strange star in the heavens and have come to worship the Redeemer. The hermit explains that this is the fulfilment of the prophecies, the Wise Men enter singing in praise of the Virgin and Child, and the play ends abruptly. 
In the Auto da Sibilla Cassandra, performed at the Convent of Enxobregas before Dona Leonor at Christmas matins, probably in 1509 or 1513 , Vicente attempted to write a Prophet's play with pastoral setting. It is well known that the Erythræan Sibyl appeared in the pseudo-Augustinian sermon Contra Iudaeos, Paganos et Arianos as one of the prophets who foretold the coming of the Messiah and pronounced the awe-inspiring prophecy of the Fifteen Signs of Judgment Day. 'A portion of this sermon was used in many churches as a lesson for some part of the Christmas offices, and the Versus Sibyllae were often sung at matins on Christmas day. Three of the twelve Sibyls known to the Middle Ages ${ }^{1}$ were introduced in this play, namely, the Erythræan, Persian and Cimmerian as the aunts of a new Sibyl to whom he gave the name of Cassandra.

The shepherdess Cassandra is courted by Solomon, but she brusquely repels his advances. Her objections to him are not personal; they are based, she claims, upon the unhappy lot of her married friends. Her aunts solicitously insist that the match would be advantageous to her, but neither their arguments nor the explanation of Moses, paraphrased from the first chapter of Genesis, that marriage is a sacrament, shakes. her preference for single blessedness.

Cassandra finally declares why she will wed no man. She believes she is the virgin in whom the Son of God will become incarnate. The Sibyls confirm this prophecy of Christ's birth. but Isaiah objects that the humility prophesied of the Virgin Mother ill accords with Cassandra's presumption. The Erythræan Sibyl recites a version of the Fifteen Signs of Judgment Day, which well illustrates Vicente's critical spirit in using medieval material, and thereupon curtains are drawn aside disclosing the Nativity scene. Four angels sing a dainty little carol, the Sibyls and Prophets worship the Christ Child, and the play ends with a charming cantiga set to music by the author himself.

1 See Georgina G. King, The Play of the Sibyl Cassandra. Bryn. Mawr Press, 1922. 
This play offers to us the first example of religious symbolism in the drama that attained well-nigh perfection at the hands of Calderón de la Barca. In spite of the disparate elements of which it is composed, it has real dramatic interest, but long after the details of the plot are forgotten, our memory is haunted by the lovely lyrics that constitute its chief charm.

In the Auto dos quatro tempos, written like the preceding, in Castilian, and performed at Lisbon before King Manuel at Christmas matins, the Christmas play is almost entirely secularized. It opens with the arrival of a seraph, arch-angel and angels at the manger where they sing a part of the $T e$ Deum in praise of the Christ Child. Winter then appears weaving his complaints of cold and rain like a chaplet for a dainty little popular song, a few lines of which are sung at the end of each strophe. Spring then presents herself singing in the same fashion one of Vicente's most charming lyrics that presents with rare beauty popular motifs. She welcomes the green valleys and meadows and the reign of Cupid that attends the renewal of life. The gaunt figure of Summer follows, exhausted by three months of heat and thirst and drought that have caused all living things to wither. Autumn also joins the group and Jupiter indulges in a long monologue in which he prophesies that the gods of Greece and Rome will be henceforth without honor and calls upon the Seasons to accompany him to worship the new-born Creator. On reaching the manger, they sing a French cantiga, and present their homage and gifts to the 'Christ Child. David, dressed as a shepherd, recites farced versions of parts of the one hundred and twenty-first, eighty-fourth and fifty-first Psalms and the canticle "Benedicite omnia opera," and the play ends with the chanting of the Te Deum.

These latter portions of the play give it a liturgical character that is not found in any Christmas play written in Spain at that period. At the same time the sacred element merely affords a setting for a version of the débat of the seasons,"

${ }^{1}$ See Biadene, Carmina de mensibus, etc., Studi di flologia romanza, vol. ix, $8 \mathrm{Iff}$. 
which is related to the medieval Conflictus hiemis et veris, and goes back ultimately to the folk-dances that celebrated the death of Winter.

Of much less consequence is the Auto da Fe, written in Castilian and Portuguese, and performed at Almeirim before King Manuel at Christmas matins, 1510. Two shepherds are dumbfounded by the magnificence of the Christmas festival and make amusing conjectures concerning some of the unfamiliar things they see. The allegorical figure of Faith then appears, who first must explain to them that Faith is love of God and of his Church, a belief in what we do not see and love for what we do not understand. In answer to their query, Faith explains why the Cross is sacred, and one of the shepherds remarks that when they need rain in his village, men and women take out a cross crying "Ora pro nubes, ora pro nubes," but the rain does not come. Other explanations of the Redemption are given, and the play ends with a song.

Three other Christmas plays by Vicente, the Auto pastoril portuguez, Auto da feira and Auto da Mofina Mendes, are composed entirely in Portuguese and therefore fall outside the limits of this study, but even a reading of the plays already discussed, all of which belong to the early years of the poet's activity, affords abundant evidence of Vicente's progress in dramatic art. An apprentice in the Monologo do vaqueiro, he successfully essayed dialogue and homely scenes of shepherds in the Auto pastoril castelhano and Auto dos Reis magos. Greater independence of Scriptural material with music and poetic fancy is found in the Auto da Sibilla Cassandra and Auto dos quatro tempos.

The question naturally presents itself whether this progress was due entirely to Vicente's creative genius, or whether influences from abroad directed this development. No one can deny some similarity between the first Christmas and Epiphany plays of Vicente and the Christmas eclogues of Encina and Fernández. At the same time, it is even more 
evident that there is no relationship between the $A$ uto da Sibilla Cassandra or the Auto dos quatro tempos and the works of the Salamancan poets. Vicente's references to French songs might be regarded as a clue to the source of his inspiration, but the French Christmas plays of that time did not possess the lyrical qualities that constitute the chief innovations in the Auto da Sibilla Cassandra and Auto dos quatro tempos. It seems more logical to suppose that in writing these plays, he took well-known medieval materials and adapted them for the purposes of a Court entertainment, similar in spirit to the maskings and disguisings that were presented at Paris and other Courts, and added sufficient sacred material to make the play suitable for representation at a religious festival.

The traditions of the Spanish religious drama were carried to Italy in the early years of the sixteenth century by Torres Naharro, who was born near the town of Badajoz. His Dialogo' del nascimiento was written at Rome between $\mathrm{I}_{5} \mathrm{I} 2$ and I517, in which year it was published with his other plays. The prologue is recited by a shepherd who gives a humorous and none too decent account of his courtship and marriage, and concludes with a brief summary of the argument.

Two Spanish pilgrims meet on Christmas Eve on their way to Rome, one coming from Jerusalem and the other from Santiago. The latter, in reply to a question, extols with patriotic ardour the success of Spanish arms which merit the pen of a Vergil or a Lucan. His companion is weary of incessant warfare which ill accords with the angel's message of peace on earth and good-will to men, and narrates incidents of the Nativity, some of which are derived from the Legenda Aurea. They then discuss theological questions, such as the relative gravity of the sin of Adam and Lucifer, and the reason why the Son was chosen as a Redeemer instead of some other person of the Trinity. The prophecies are related in some detail, and also the Annunciation, which bears a strong resemblance to Gil Vicente's version of the same 
scene in the Auto da Mofina Mendes (1534). This pious discussion is interrupted by two shepherds, skilled in sophistry, who ask the pilgrims absurd questions and riddles. ${ }^{1}$ They then engage in a contest of abuse, ${ }^{2}$ and the play ends with a sacrilegious farced version of the Ave maris stella, which seems to reproduce at least the burlesque spirit of the Boy Bishop revels.

The play is lacking in dramatic interest because the author aims to commemorate rather than represent the Nativity. In common with the plays of Fernández, it has a marked theological tone and resembles the latter's Egloga o farsa del nascimiento in the absurd questions asked the pilgrims by the shepherds. Compared with the dramatic power of some of Torres Naharro's secular plays, this composition is only an interesting curiosity. The author makes an interesting modification in the coplas de arte mayor which was followed by Vicente in his Auto de historia de Deos and Auto da feira. ${ }^{3}$

The influence of Encina and Fernández is still more evident in the Egloga en loor de la natividad de muestro Señor of Hernán López de Yanguas, probably written before 1518.* Four shepherds have heard the news of Christ's birth and discuss like theologians the fulfilment of the prophecies. We do not need the marginal notes carefully inserted by the author to recognize his dependence upon the Old and New Testament, including such unpromising dramatic material as the Liber generationis, which is translated in full. They offer their gifts to the Virgin, and the play ends with a song and

${ }^{1}$ For certain of these riddles, see Rudolph Schevill, Some Forms of the Riddle Question, University of California Publications in Modern Philology, vol. ii, I9II.

2 For the contest in abuse found in so many sixteenth-century plays, see J. P. W. Crawford, Echarse pullas. A Popular Form of Tenzone, Romanic Review, vol. vi, 1915.

${ }^{3}$ Menéndez y Pelayo's introduction to the Propalladia of Torres Naharro, vol. ii, p. xc.

"Kohler, Sieben spanische dramatische Eklogen, pp. I53-55. 
dance. By reason of its unrelieved didacticism, this play is one of the most wearisome composed in Spain in the sixteenth century. ${ }^{1}$

The Farsa nuevamente trobada of Fernando Díaz shows no advance over the Christmas plays of Encina and Fernández. Composed like the preceding one in coplas de arte mayor, it presents a quarrel between two shepherds, which is followed by the appearance of an angel, who announces to them that Christ is born. The angel then assumes the rôle of a theologian, and explains in detail the doctrine of Redemption. The shepherds offer their gifts at the manger and the play ends with a song. The only edition that has been preserved bears the date 1554 , but its primitive character allows us to date it, in all probability, about the year $1520 .{ }^{2}$

The Farsa a honor y reverencia del glorioso nascimiento de nuestro Redemptor y de la Virgen gloriosa madre suya of Pero López Ranjel, printed about I530, shows little advance over the Christmas plays of Encina. Other plays belonging to this early period that deal with incidents of the Christmas story are the Auto nuevo del santo nascimiento de Cristo nuestro Señor by Juan Pastor, printed at Seville in I 528, and the Auto de como San Juan fue concebido y ansi mesmo el nacimienta de San Juan by Esteban Martínez, published at Burgos in the same year. To this period also belongs an Incarnation play entitled Triaca del alma by Fr. Marcelo de Lebrixa, with only female rôles and written for performance by nuns. ${ }^{3}$

The outstanding figure in the Spanish religious drama of the first half of the sixteenth century is Diego Sánchez de Badajoz (or Diego Sánchez), whose twenty-eight plays were published posthumously by his nephew about the year 1554 with the title Recopilacion en metro. Little is known of his life, save that he was curate at Talavera, near Badajoz, from

${ }^{1}$ A fragment of a play of similar tone was published by Cotarelo y Mori in the Revista española de Literatura, Historia y Arte, vol. i, IgoI.

${ }^{2}$ Kohler, op. cit., p. r8r.

'Schack, op. cit., vol. i, p. 334-36. 
1533 to 1549 and died in the latter year or the year following. His dramatic activity extended approximately from 1525 to 1547. His plays, all of which bear the name farsa, are difficult to classify. It appears from internal evidence that twelve of these were performed on Christmas, ten on Corpus Christi day, two on Saints' days and four on other occasions.

Limiting ourselves for the present to the Christmas plays, only two, namely, the Farsa de la Salutacion and Farsa de los doctores, deal with incidents of the Christmas story. The first presents with the simplicity of the Gospel accounts the Annunciation to the Virgin; the second shows the youthful Jesus teaching the doctors in the Temple, with the addition of incongruous elements.

Theology is more prominent in the Farsa de la Natividad and Farsa teologal. In the former, a malicious shepherd stages a quarrel between a parish priest and a friar regarding the relative joy of the Virgin at the Nativity or Incarnation, which is settled by the allegorical figure of Learning. This dispute seems to be a burlesque of scholastic argumentation in general, and probably refers to some over-animated controversy with which the clergy of Badajoz was familiar. ${ }^{1}$ In the Farsa teologal, the ignorance of a shepherd! offers an opportunity to a theologian to explain at length the doctrine of Redemption. With the serious part of the play out of the way, the author was left free to entertain the audience with a comic scene of rude horse-play in which he excelled. The shepherd devises a sort of jack o' lantern which frightens a young negress. A' soldier then enters, boasting of his prowess on many a battle-field, but he faints away when he sees the jack o' lantern, and on recovering his senses, calls for a priest to hear his confession. When the priest arrives, the braggart has recovered somewhat his composure and explains that his weakness has been caused by severe toothache. $\mathrm{A}^{\prime}$ French dentist is summoned who is led by professional zeal to

'J. López Prudencio, Diego Sánchez de Badajoz, Madrid, I915, pp. I51-57. 
extract not only one, but two perfectly sound teeth before the soldier's pleas for mercy are heeded. The incident is worked out with such completeness that we must regard it as a primitive paso, and in its dramatic interest, it is entitled to rank with the best short compositions of Lope de Rueda.

Two of the plays of Sánchez de Badajoz performed at Christmas, namely, the Farsa de Salomon and Farsa de Tamar, deal with Old Testament themes. The first presents the familiar story of the decision rendered by Solomon in a dispute between two women regarding the ownership of a child, which is explained by a friar according to the interpretation of St. Augustine. The scene that follows shows that the ignorant shepherd was sometimes able to protect himself when imposed upon. A friar tells him that every good Christian should chastise himself in order to become pure of heart. The shepherd acts at once upon this advice, undresses and gives himself a good thrashing. Then the friar tells him that he was joking, but the shepherd prophesies that their roles may be reversed, and makes good his promise for he gives the friar a sound flogging in return. The Farsa de Tamar treats a salacious episode from Genesis, and ends, strangely enough, with the announcement of the birth of Christ.

Owing to their use of allegory, four of the plays performed at Christmas, namely, the Farsa moral, Farsa militar, Farsa racional del libre albedrio and Farsa del juego de cañas, may be classified as Moralities. The Farsa moral combines the defeat of Wickedness by the Cardinal Virtues, Job's reward for his confidence in God's mercy, the madness of Nebuchadnezzar and the final victory over Wickedness as a consequence of the birth of Jesus. One of the best plays of Sánchez de Badajoz is the Farsa militar which presents a friar who, after successfully resisting the temptations of Lucifer, World and Flesh, falls a victim by reason of an insidious appeal to his vanity and ambition, and ultimately vanquishes his enemies by confession, contrition and penitence. It contains a paso which recalls Timoneda's $P$ asso de dos ciegos y un mogo, and 
ends with a scene in which the inability of a deaf man to understand the announcement of Christ's birth furnishes the chief comic element. An alternative ending is also given in the printed version in which there is a reference to the battle of Mühlberg in I547. The play does not appear to be anticlerical in spirit, but is rather a warning that even the most virtuous must be constantly on their guard against temptation. Theological abstractions are carried to the point of dullness in the Farsa racional del libre albedria, in which Free Will, after a narrow escape from the wiles of Sensuality, is wedded to Reason. The Farsa del juego de cañas is a Prophet's play, treated in the form of fantastic allegory with a delightful lyrical spirit which may be derived from Gil Vicente. The Farsa de la ventera is a secular farce with only the slightest relation to Christmas. This little play gives evidence of the author's intimate knowledge of picaresque types and of his ability to construct a comic scene with real dramatic interest.

Each of these plays of Sánchez de Badajoz is preceded by a prologue, recited by a shepherd who greets the audience in a bantering air, and occasionally introduces the first character with a summary of the argument. At times he boasts of his skill in sports, games and music or relates with salacious and even obscene details some incident of his domestic life. In the prologue to the Farsa de Tamar, the author's stern moral attitude is shown in his arraignment of the feminine practice of veiling the face, and in the Farsa de Salomon, the prologuist bitterly protests against selfish lust for gold and the inequalities between the rich and poor, a subject that forms the basis of the same author's Farsa de la Fortuna o hado. These prologues may have been imitated from the introitos of Torres Naharro, but I am inclined to believe that they represent an independent outgrowth of the dramatic monologue which, by analogy with French literature, we may assume was one of the favorite forms of entertainment of the juglares.

In nearly all of these early Christmas plays, the shepherds have an important rôle. Employed at first to give a rustic set- 
ting to the Nativity scene, both entertainment and a pretext for instruction were obtained from their ignorance of sacred symbols and dogma. In the course of time, the shepherd's part becomes increasingly important as may be seen in the plays of Sánchez de Badajoz. In the prologue to the Farsa de la Natividad, the shepherd says that devout and profitable things will be recited, and in order "that you may not fall asleep, we shall tell you some funny things at which you may laugh". This became the shepherd's chief function, and since his value as a comic figure consisted chiefly in his stupidity, he was frequently designated as the bobo or simple. Usually represented as a glutton, he has no desire beyond a well-filled stomach. $\mathrm{He}$ is impertinent and makes sport of everything, sacred and profane. In demanding an explanation of theological doctrines, he serves as a connecting link between the audience and the serious characters, because he looks at everything from the same standpoint as the humblest peasant among the spectators. ${ }^{1}$

It is a debatable question whether the comic figure of the shepherd is a logical outgrowth of the shepherds' plays as an introduction to the Nativity, or whether we may see in him the influence of popular farce. There is no question that the bobo combined the characteristics of Maccus the fool and Manducus the guzzler of the Roman fabulae Atellanae, but whether he is their lineal descendant is difficult to determine. The many references to the fool or clown in all the countries of Western Europe during the Middle Ages lead us to believe that with the secularization of the religious plays, the fool and other popular entertainers entered into more dignified company and found a place for themselves in the plays presented at Christmas, and later at Corpus Christi and other festivals.

In addition to the shepherd, other characters were frequently employed by Sánchez de Badajoz for comic effect.

${ }^{3}$ J. P. W. Crawford, The Pastor and Bobo in the Spanish Religious Drama of the Sixteenth Century, Romanic Review, vol. i, I910. 
As in other countries, the devil appeared in many Spanish plays, conventionally costumed with horns, tail and cloven feet, and was brought to terms by the bobo as in the Farsa de los doctores. The braggart soldier, who resembles somewhat the Plautine Pyrgopolinices, but who seems to be a product of Spanish conditions, had a distinguished career in the sixteenth century drama, and sometimes appeared in Christmas plays as in the Farsa teologal. The negress slave, speaking an almost incomprehensible jargon, also became a conventional comic figure. The futile effort of the bobo to teach one of these poor creatures the Creed in the Farsa teologal will be long remembered.

In all these comic incidents the shepherd occupies the central place, and in time a short farce with dramatic unity was developed in the body of a serious play. This stage is reached, for example, in the Farsa teologal. There can be no doubt that these brief comic scenes contain the first germ of the paso and that they had a very considerable influence upon the development of comedy. Their popularity was so great that they were introduced into religious plays that had no relationship with Christmas, and into the secular drama as well.

Judging from the number of extant plays, Good Friday and Easter contributed less than Christmas to the creation of the religious drama. The earliest of such compositions, after Encina, is Lucas Fernández's Auto de la Pasion, published with his other works in r514. Here St. Peter, bitterly regretting his denial of Christ, is joined by St. Dionysius of Athens, to whom he relates the incidents of the Passion. . St. Matthew adds further details and the three Maries enter, chanting their laments in the form of a planctus of marked liturgical character. The Crucifixion scene is tenderly described, following literally in many cases the Scriptural account, a Crucifix is displayed and all kneeling chant a stanza of the Vexilla Regis. Jeremiah mourns the suffering-Christ in language borrowed in part from Lamentations, the Descent from the Cross is narrated, and all kneel before the monument 
or altar that represented the sepulchre, singing in honor of the Crucified One.

The liturgical element is more pronounced here than in any other Spanish play. It has little dramatic quality, since the incidents are narrated rather than represented, but it is pleasing by reason of its use of lyrical sacred texts, the planctus of the three Maries and the considerable musical element. It is almost certain that it was performed in church on Good Friday by members of the clergy.

We also have a primitive form of the Officium Peregrinorum in Pedro Altamira's Auto de la aparicion que nuestro' Señor Jesucristo hizo a los discipulos que iban a Emaus, published at Burgos in 1523. As its title indicates, it deals with the appearance of the Risen Christ to Luke and Cleopas, as recorded by St. Luke. One Easter and three Passion plays recently discovered belong to approximately the same period. ${ }^{1}$

It is a noteworthy fact that there is scarcely a trace in Spain in the first half of the sixteenth century of the composition of plays embracing in a cycle the chief incidents of sacred story from the Creation or the Fall of Lucifer, such as we find in France and England. This seems to offer an argument in favor of the independent development of the Spanish religious drama. The few extant plays written during that period that treat Old Testament and New Testament material may be classified as independent Corpus Christi compositions. It is unfortunate that the seventeen plays written in the early part of the sixteenth century by Vasco Díaz Tanco de Frexenal for performance on the Sundays of Lent, Holy Thursday, Good Friday and Easter, have not been preserved. These dealt with incidents of the Ministry and Passion of Christ, culminating in the Resurrection, and are the

${ }^{1}$ Revista de Archiz'os, vol. vii, 1902, p. 253. Gil Vicente's Dialogo sobre a Resurreição, composed in Portuguese, presents three rabbis who discuss the news of Christ's Resurrection. 
only evidence that we have of such serial performances in Lent. $^{1}$

The Assumption of the Virgin was celebrated with special ceremonies in many cities, but the only extant Castilian play of the first half of the century written to honor that festival is the Farsa del Mundo y moral by Hernán López de Yanguas. ${ }^{2}$ Here the shepherd Appetite, who represents mankind, enters the service of World on the promise of receiving honours and untold wealth. A hermit exposes the snares that World has laid for the poor shepherd and bids him enter the service of Faith, if he wishes to be saved after death. Appetite, thoroughly frightened over his narrow escape, promises to do so and tells World very plainly that he will have nothing further to do with him. World is obliged to admit his defeat and Faith describes the court of Heaven on the occasion of the Assumption of the Virgin. In that celestial multitude were Ferdinand and Isabella who gloried in their victories over the infidels and prophesied that their grandson, Charles, would carry the faith to Asia. The poetic inspiration of López de Yanguas did not equal his pious zeal and his didacticism and abuse of classical allusions are often wearisome.

It is probable that the festivals of certain Saints were occasionally celebrated by the performance of appropriate plays, but the only extant examples of these in the first half of the century are the Farsa de Santa Barbara and Farsa de San

\footnotetext{
${ }^{1}$ For the titles, see the prologue to his Jardin del alma cristiana (1552), published in Gallardo's Ensayo de una biblioteca, vol. ii, cols. 785-86. Since the author refers jokingly to his advanced age in this prologue, and states that these plays were composed in his youth, we are justified in ascribing their composition to approximately the first decade of the century.
}

2 The first edition is of 1524 , but it was probably written between 1516 and 1520. See Cotarelo y Mori, Revista de Archivos, vol. vii, I902, pp. 259-60 and Kohler, op. cit., pp. I50-53. An incomplete Valencian play on the Assumption and Death of the Virgin of the beginning of the fifteenth century has also been preserved. See H. Mérimée, op. cit., p. 45-57. 
Pedro of Sánchez de Badajoz. The first was doubtless performed at Badajoz where Santa Barbara was held in especial devotion. After the prologue, the figures of Christ and Santa Barbara are disclosed. An angel relates the patient suffering and heroic death of the young martyr for the sake of her Christian faith, while a devil, who acts as prosecutor, declares that she deserves condemnation because she was born of pagan parents. A shepherd comments wittily upon the arguments presented and affirms that the women he knows are not capable of such sacrifice as she had shown. Finally he loses patience with the devil and drives him away. Christ then places upon the maiden's head a crown of gold, one of roses and one of lilies, and the play concludes with a villancico in praise of 'Christ. The Farsa de San Pedro has as its central point the incident related by St. Matthew concerning the miraculous fish that should yield the tribute-money that was exacted from Jesus by a tax-collector.

We have already seen that by the year 1360 the representation of certain sacred scenes formed a part of the Corpus Christi procession at Gerona. Documents for the Castilianspeaking portions of the Peninsula are both of later date and less specific, but we can say that throughout Spain the Corpus festival had acquired considerable importance by the latter half of the fifteenth century. Until the middle of the sixteenth century, the duty of organizing and paying for the cars or pageants upon which these scenes were represented generally fell to the lot of the various guilds, and it is probable that the different scenes were distributed in such a way as tol bear some relation to the craft that presented it. ${ }^{1}$ It is difficult to determine from the available documents at what

\footnotetext{
${ }^{1}$ For Seville, see José Sánchez Arjona, Noticias referentes a los anales del teatro en Sevilla, p. 9. The municipality assumed this function somewhat later at Valladolid; see N. A. Cortés, El teatro en Valladolid, Boletín de la Real Academia Española, vol. iv, 1917, pp. 600-606. On the manner of presenting Corpus plays, see H. A. Rennert, The Spanish Stage in the Time of Lope de Vega, New York, I909, chap. xiv.
} 
period these Corpus Christi shows passed from the stage of tableaux vivants to plays with dialogue and action.

It is likewise a debatable question whether the scenes represented in the pageants of the early Corpus processions had any relationship with the festival itself, and also whether the first Corpus plays contained any reference to the Eucharist. ${ }^{1}$ The scenes represented on Corpus Christi day at Gerona in I360, namely, the sacrifice of Isaac and the dream and sale of Jacob, seem to have been chosen in order to explain the symbolical meaning of the Eucharist. The connection is less clear in the case of the subjects of pageants that we find in later documents, but it is likely that couplets referring to the Eucharist, of which there are a number of examples in the Cancioneros of the fifteenth century, may have been recited to interpret any sacred scene. It is true that Vicente's Auto de $S$. Martinho, usually regarded as the earliest auto sacramental in Spanish, was performed on Corpus Christi day in I504 and contains no reference to that festival, but since the play is incomplete, it does not offer conclusive evidence that a play totally unrelated in subject to the Eucharist might be used for a Corpus celebration.

At all events, the earliest extant Corpus Christi play written by a Spanish author deals exclusively with the Eucharist. This is the Farsa sacramental of Hernán López de Yanguas, first published about the year ${ }^{5} 520$. Here with the setting of a primitive Christmas play, after the manner of Encina and Fernández, the significance of the Eucharist is explained by an angel to four shepherds, Jerome, Augustine, Gregory and Ambrose. We find here the tendency toward allegory, symbolism and theology that was destined to play so important a part in the development of the auto sacramental. Closely resembling the foregoing is an anonymous Farsa sacramental, composed in coplas de arte mayor and printed in $\mathrm{r}_{52 \mathrm{I}}$. This presents a conversation between three shepherds and the alle-

1 This question is discussed by Cotarelo y Mori, Revista de Archivos, vol. vii, Igo2, pp. 25I-52, and by López Prudencio, op. cit., pp. 256-60. 
gorical figure of Faith, who explains to them the doctrine of Redemption and the mystery of Transubstantiation.

The Corpus Christi plays of Sánchez de Badajoz show a wider variety of material and a notable advance in dramatic construction. Four of these, namely, the Farsa de Isaac, Farsa de Abraham, Farsa de Moysen and Farsa del rey David, treat Old Testament stories that have a close symbolical relationship with Christ's sacrifice. The first presents the substitution of Jacob for Esau in receiving Isaac's blessing, and ends with the explanation that the blessing bestowed upon Esau represents the freedom from the supremacy of Judah given to all peoples by the coming of the Messiah. The Farsa de Abraham is an insignificant play containing a symbolical explanation of the Eucharist. In the Farsa de Moy$s e n$, St. Paul interprets the symbolical relationship of portions of the Old and New Testaments and expounds the meaning of the Corpus festival. The Farsa del Rey David establishes the symbolical connection between David and Christ.

The rubric of the Farsa de Santa Susana informs us that the play was performed on a car that represented a garden. The introit or prologue is of unusual interest because it is in dialogue form. A shepherd and gardener engage in a dispute regarding the relative value of idleness and industry. The shepherd presents eloquent claims in favor of indolence, while a gardener extols the benefits of labor and assails slander and gossip as fruits of idleness. In the course of his argument, he makes a defense of his own trade, which closely resembles the form of loa that was frequently used in the time of Agustin de Rojas. The play proper is intended to illustrate the evils of slander and therefore has organic connection with the prologue. The material is taken from the familiar story told in the thirteenth book of Daniel. The characters are vividly portrayed, with an intensity rarely found in these early plays, and the interest is well sustained through a series of dramatic situations.

A friar teaches the significance of the Eucharist in the 
Farsa del Santisimo Sacramento, which has the same setting as the Christmas plays of Encina and Fernández. The virulent attack of the shepherd upon the friar should not be regarded as evidence of an anti-clerical attitude on the author's part, but rather as inspired by a desire to correct popular prejudices. The Farsa de la Iglesia contains an allegorical débat between Church and Synagogue, and includes a comic scene in which a shepherd attempts to baptize a Moor. ${ }^{1}$ The Danza de los Siete Pecados represents the defeat of Adam by the seven Deadly Sins and finally his realization of God's mercy as revealed by the Eucharist.

The Farsa del molinero, Farsa del colmenero and Farsa del herrero offer concrete proof of the participation of the tradeguilds in the Corpus Christi plays. In each of these, a eulogy or defense of the particular trade forms the most important element and the portions referring to the Eucharist are insignificant. It is reasonable to suppose that these guilds paid for the cars on which the plays were performed and also furnished the actors. The Farsa del herrero contains a reference to the presence of the smiths in the procession.

It is likely that most of the plays of Sánchez de Badajoz were performed at Badajoz in the presence of the Cathedral Chapter. It also appears that the Farsa de la Iglesia was presented on Corpus Christi day at Seville in 1560 , and it is likely that the Farsa militar and Farsa moral were performed at Seville in the following year with the titles La soberbia $y$ caida de Lucifer and Rey Nabucdonosor. ${ }^{2}$

The sale of Joseph by his envious brethren and the incidents of his sojourn at the court of Pharaoh, one of the most dramatic stories found in the Old Testament, is the theme of the Tragedia llamada Josefina by Micael de Carvajal. The ear-

${ }^{1}$ The conversion and baptism of a Moor are incidents found in many later plays. See G. I. Dale, The Religious Element in the Comedias de moros $y$ cristianos of the Golden Age, Washington University Studies, vol. vii, St. Louis, I9I9.

${ }^{2}$ José Sánchez Arjona, op. cit., p. 26. 
liest extant edition is of the year 1540 , but an edition of 1535 is mentioned in the Registrum of Fernando Colon and there is some evidence that it was written before $\mathrm{I}^{23}$. The name of tragedy suggests classical influence and the chorus of maidens that sings at the close of each of the four acts has the same source, but in other respects the play has little in common with classical tragedy. An unusual feature in the plays of the time is the prologue recited by Envy, Furia infernal, which may be classical in inspiration or may have been suggested by the prologue to the Vendition de Joseph which formed a part of the Mistère du Viel Testament. ${ }^{1}$ Carvajal gives life and dramatic intensity to the scenes in which he describes the jealousy of Joseph's brethren, the mourning of Jacob over the loss of his son and the passion of Potiphar's wife. Its relationship with the Corpus festival is by no means clear and its suitability for such an occasion may be doubted, but its superiority to the other Spanish religious plays of the time cannot be questioned.

The only other extant Corpus play that can definitely be assigned to this early period is Sebastian de Horozco's $R e$ presentacion de la parabola de Sant Mateo, performed at Toledo in 1548 . This dramatic version of the Parable of the Vineyard has no apparent relationship with the Corpus festival and its interest lies in the portrayal of characters taken from every-day life. The two peasants, two ex-soldiers just released from Algerian prisons and now reduced to beggary, two starving solicitors for religious orders, an old countryman and his dolt of a son who are engaged, one after another, for work in the vineyard, furnish a social background which seems to bespeak the unrelieved misery of the common people.

More important is Horozco's Representacion de la historia evangelica del capitulo nono de Sanct Joan which deals with the healing of a blind man by Jesus. In the first scene we

${ }^{1}$ A. Morel-Fatio, Romania, vol. xv, I886, p. 467. The play also contains elements derived from Jewish traditions. See A. Bonilla y San Martín, Las Bacantes o del origen del teatro, p. I4I. 
have virtually a dramatization of a part of the first chapter of Lazarillo de Tormes. A blind beggar accuses his guide named Lazarillo with pocketing food intended for himself. Lazarillo has stowed something away, but his master detects it by the odour. "It is bacon", he declares, "I smell it". While they are disputing over the question of rations, Lazarillo allows him to strike against the wall of a house. When the beggar cries out with pain, Lazarillo says grimly, "Since you smelled the bacon, why didn't you smell the corner?" The whole spirit of this scene, as well as the verbal similarity of the last words with the "Olistes la longaniza y no el poste?" of the novel, unmistakably show the influence of Lazarillo de Tormes upon the play, or what is less likely, the influence of the play upon the novel. The suggestion ${ }^{1}$ that the resemblance between these two compositions must be explained by common authorship is interesting, but seems to lack sufficient evidence. The question of their relationship is obscure because the date of composition of the play is even more uncertain than that of the novel.

In the rest of the play, the picaresque element is less prominent. The beggar is led before Jesus who anoints his eyes and promises that he will recover his sight if he will bathe in the pool of Siloam. This is followed by a comic scene to which the author gives the name of entremés, one of the earliest examples of the use of this term to denote a dramatic composition inserted within a play. Here an impecunious lawyer is introduced who insists on taking all his client's money as a retaining fee and for various expenses. The beggar returns with his sight restored and falling upon his knees, worships the Saviour.

${ }^{1}$ Julio Cejador y Frauca, Historia de la lengua y literatura castellana, vol. ii, pp. 238-250. On the relationship between these two compositions see also Cotarelo y Mori, El licenciado Sebastián de Horozco y sus obras, Madrid, 1916, pp. 40-44, and the notes of Charles P. Wagner to Louis How's English translation of Lazarillo de Tormes, New York, 1917, pp. 131-32. 
We must return once more to Portugal and to Gil Vicente to find the most important morality play composed in the Peninsula in the first half of the sixteenth century. His trilogy of the Three Boats, performed in 1516 or 1517 , I 518 and 1519 respectively, combine the spirit of Lucian and the medieval Dance of Death. The Auto da barca do Inferno, written in Portuguese, presents in turn a nobleman, usurer, peasant, shoemaker, friar, bawd, Jew, magistrate, lawyer, thief and four knights who are claimed by Death as passengers on the boat about to set sail for Hell. Each claims the right to be saved, but all are rejected except the simple-hearted peasant and the four knights who had fallen for the cause of Christ on African battle-fields, and to these latter the poet pays eloquent tribute. The figure of inexorable Death who grimly lays bare the souls of his victims, unscrupulously exposing their meanness, greed, deceit and lust, is a powerful conception unsurpassed in the Peninsular literatures in the sixteenth century. An anonymous Castilian adaptation of this play, which closely follows its Portuguese original, was published at Burgos in 1539 with the title Tragicomedia alegorica del Parayso y del Infierno. ${ }^{1}$

Less significant is the Auto da barca do Purgatorio, written in Portuguese and presented at Christmas matins of 1518. In the Auto da barca da Gloria, composed in Castilian and performed the following year in the presence of King Manuel, the devil insists that Death shall bring him men of high estate who had escaped judgment in the two previous plays. In accordance with these orders a count, duke, king, emperor, bishop, archbishop, cardinal and pope are brought before the boatman of Hell who acts as prosecutor. With uncompromising severity their sins are set forth and the torments that await them are graphically described. They remind him of

${ }^{1}$ For the relationship between these two plays, see W. S. Hendrix, The Auto da Barca do Inferno of Gil Vicente and the Spanish Tragicomedia del Parayso y del Infierno, Modern Philology, vol. xiii, 1916, p. 669, and a note in Modern Language Notes, vol. xxxi, I916, pp. 432-34. 
their exalted station in life, and he accuses them of having been false to the responsibilities entrusted to them. Even the pope is not spared, who is charged with lust, pride and simony. Their appeals for mercy are unheeded by the angel in charge of the Paradise boat, and only by the intervention of the Risen Christ at the close of the play can they obtain salvation. Gil Vicente cannot truly be regarded as a precursor of the Reformation in Portugal, but in these plays, as elsewhere, he shows himself an ardent champion of social justice and of a high moral code among all members of the clergy. It is possible that these plays suggested to Lope de Vega certain features in his auto, El viaje del alma.

The influence of the medieval Dance of Death is found again in the anonymous Coplas de la Muerte como llama a un poderoso cavallero, printed about the year I530. An analogous conception is seen in Sánchez de Badajoz's Farsa de la Muerte, in which an old man battles valiantly against Death, but with a consciousness that his defeat means a release from the sorrows of this world and the beginning of everlasting happiness. 


\section{CHAPTER IV}

\section{Festival and Pastoral Plays}

We have already seen that the Royal Entry and important political events were frequently celebrated in the fifteenth century by processions and allegorical pageants. With the courtly masquerade as a contributing factor, these developed into festival plays by a process analogous to that of the gradual transformation of the Corpus Christi shows into religious drama. One of the earliest examples of this new type is an Egloga without title by Francisco de Madrid, written toward the end of $1494,{ }^{1}$ and treating of the invasion of Italy by Charles VIII and the consequent repudiation by Spain of the treaty of alliance with France. The interlocutors are three shepherds, two of whom represent Charles VIII and Ferdinand. We do not know where this play was performed, nor on what occasion, but its relationship with later compositions on political subjects is clear.

More elaborate is the Comedia Trofea of Torres Naharro, performed at Rome in 1514 in honor of the important mission led by Tristao da Cunha which had been sent by King Manuel to negotiate with Leo $\mathrm{X}$ for a subsidy to be used in extending Portugal's colonial empire in Asia. It is not known under whose patronage the play was written and performed, but it is evident that Torres Naharro attempted to present the Portuguese claims in the most favorable light. Preceded by a comic prologue and composed in five acts of coplas de pie quebrado, the play consists of five loosely connected scenes,

${ }^{1}$ Cañete, Teatro español del siglo XVI, pp. 50-51, and Kohler, op. cit., pp. $158-59$. 
almost totally devoid of action. The extravagant praise of Manuel the Fortunate, recited by Fame in the first act, and the presentation by the interpreter of the twenty pagan kings who joyfully and ingenuously offer allegiance to so exalted a monarch, remind us of earlier masquerades, and an attempt is made to enliven these rather dreary narrative portions by the introduction of farcical scenes of shepherds. It is difficult to determine whether, for its form, the author was indebted to Italian festival plays of the same type as Sannazzaro's Il Triumpho della Fama, performed at Naples in 1492 to celebrate the capture of Granada, or whether it represents a logical development of Spanish allegorical pageants and masquerades.

It is true, as Menéndez y Pelayo said, that inspiration was lacking to Torres Naharro in this play and that his failure was as complete as the shepherd Mingo's attempt to emulate Fame and to fly with a pair of borrowed wings. At the same time, the Comedia Trofea has a vast amount of historical interest. It recalls, in the first place, the details of that mission which was to show in concrete form the glories of the newly-won Portuguese empire. In order to win the Pope's favour and support for fresh conquests, the famous Tristao da Cunha and his associates brought with them as gifts trophies of priceless value, and not the least of the trophies was an elephantthe first to be seen in Italy for centuries-dubbed Annone, which became a figure of national importance, was painted by Raphael and whose death three years later, was mourned in mock-elegies by noted poets of the day.

The play serves, too, as a record of the glorious achievements of Portugal in its heroic age. Thanks to the impulse given to geographical discoveries by Prince Henry the Navigator, one African cape after another had been doubled until finally Vasco da Gama crossed the Indian Ocean and cast anchor at 'Calicut in the year 1498 . The right of King Manuel to the title "Lord of the navigation, conquest and commerce of Ethiopia, Persia, Arabia and India" was confirmed by 
Alexander VI in $\mathrm{I}_{502}$ and the marvellous exploits of the great Affonso d'Albuquerque between I507 and I5II had established Portuguese supremacy in the East. We must regard as literally true the statement made by Fame in the first act that Manuel was lord of more lands than Ptolemy himself described. The twenty pagan kings who present themselves to acknowledge the authority of Manuel and to request baptism were the living witnesses of the Portuguese conquests in Guinea, Aden, Ormuz, Goa and Cochin China. Surely the king's inordinate vanity must have been tickled by all this flattery, even though as a play the Comedia Trofea is far inferior to Gil Vicente's tragicomedy entitled Exhortaçao da guerra which he had witnessed the year before at Lisbon to celebrate the departure of an expedition against Azamor.

The eventful visit of Charles I to Valladolid was celebrated by the performance of an Egloga real in December, 1517 , composed by a school-master, Fernando de (or del) Prado. ${ }^{1}$ With a pastoral setting, the play voices the welcome of the various estates of Castile and their fervent desire that he succeed to the throne, and contains a prophecy of his future greatness. History tells us that in this first meeting with his Cortes, Charles did not receive such unanimous support from his subjects. There were many causes for friction and dissatisfaction and he was not actually recognized as joint ruler with his mother until he had promised to maintain Castilian privileges and to exclude foreigners from office. It was further stipulated that complete authority should pass to his mother, Juana, if she should recover her reason. Written in stilted, pompous language and with an abuse of classical allusions, the play is chiefly of interest as an attempt to glorify the future Emperor by a biased presentation of facts.

The author, who signed himself, "bachiller de la Pradilla,"

${ }^{1}$ For a discussion of the identity of Fernando de Prado, see an article by Bonilla y San Martín, Fernán López de Yanguas y el bachiller de lo Pradilla, published in the Revista critica hispano-americana, vol. i, 1915, pp. 44-51. 
was born at Pancorbo in the province of Burgos and studied at the University of Salamanca where he was one of the first pupils of Lebrixa. After teaching his master's new methods for some time at Alcaraz, he became professor at Santo Domingo de la Calzada. A passage in the play refers to a composition written by him at Vitoria in Latin and Castilian in honor of the parents of Charles, and the rubric of our play informs us that it was first composed in Latin. He also is known to have written in Latin and Castilian an eclogue in honor of the election of Juan Ortega as Bishop of Calahorra.

Another play which is chiefly of historical interest is the Farsa sobre la felice nueva de la concordia e paz e concierto de nuestro felicisimo emperador semper augusto, e del cristianisimo rey de Francia of Hernán López de Yanguas, written to celebrate the Peace of Cambray between Spain and France which was signed on August I5, I 529. Spain had reason to rejoice over this treaty which imposed humiliating terms upon Francis I and made Charles sole arbiter of the destinies of Italy. However, although the note of rejoicing is present, the play seems to have been chiefly inspired by a profound sense of relief at the cessation of warfare. War, who appears in the guise of a pilgrim, tries to justify herself, but Peace and other allegorical figures paint in vivid colors the havoc that she works in the world, and banish her from the kingdom. Satisfaction over the Ladies' Peace was of short duration, for Spanish troops were still fighting on other battle-fields, and only a few years later war once again broke out between Spain and France.

A good example of the courtly masquerade of the period is found in the Farsa of Luis Milan, performed at the Royal Palace of Valencia in the presence of the Duke of Calabria and Germaine de Foix between the years 1530 and $1538,{ }^{2}$ and first printed in his book on courtly manners, entitled $E l$ Cortesano, in $156 \mathrm{I}$. In this little entertainment, seven knights of the Order of St. John successfully engage in turn seven

${ }^{1} \mathrm{H}$. Mérimée, L'Art dramatique d Valencia, pp. 88-94. 
Turks who had captured their sweethearts on the high seas. Knights and ladies then joyfully celebrate their reunion. The Turks apparently bear no ill-will for their defeat and dance a ballet. This is followed by a tourney, after which all the actors present themselves before the Duke and announce their intention of returning to Malta.

Entertainments of this sort, with their mingling of recitation, pantomime, singing, dancing and fencing were frequently presented at many of the Italian Courts in the closing years of the fifteenth century and it is natural to suppose that these elaborate ballets were introduced in Valencia by the Duke of Calabria or members of his entourage. Other ballets of a less dramatic character are also described in El cortesano. Whatever their origin, these entertainments belong more properly to the history of the mask than to the drama.

No other form of literature is so completely dependent upon patronage as the festival play. The most gifted poet might display his imagination and fancy in writing a play to celebrate some event, but he could not produce it without the encouragement and financial aid of a wealthy patron. The festival play was dependent upon private initiative because of the large expense involved in adequately staging it. Architects, painters and musicians were required to give a proper setting and a cultured audience was needed to properly appreciate it. From the outset, the festival play was a product of the artistic ideals of a small aristocratic group. Courtly conceptions of life and of art were mirrored in these entertainments, and if comic scenes of low life were introduced, it was only to serve the purpose of a foil. Poliziano's Orfeo reflects the love of the beautiful that animated the Court of Lorenzo de' Medici, as the Aminta and Il Pastor Fido represent the literary traditions of Ferrara. The court of the learned Elizabeth is pictured in the court entertainments of John Lyly and the passion of her successor for shows and pageants finds expression in the masques of Ben Jonson. In order to avoid the commonplace and to give free rein to the 
fancy of the poet, the art of the painter and the skill of the architect, these festival plays gradually assumed the form of spectacles in which allegorical and mythological material was employed to connect a series of beautiful scenes.

We must explain the retardation in the development of the festival play in Spain of the sixteenth century by a lack of royal patronage. The Emperor was not a man of letters and seems to have given no encouragement to play-writers. Philip II was more interested in theology than in the theatre, and not until the reign of Philip IV did royal dramatic entertainments on a lavish scale come into vogue.

Happily, the external conditions that contributed to the development of festival plays at Florence, Naples, Ferrara and London were present at the court of Manuel I at the very beginning of the sixteenth century. The Portuguese Crown was enormously wealthy, and the King was abundantly able to gratify his taste for luxury. The magnificence of the palace of Belem, near Lisbon, is eloquent testimony of his interest in art and architecture. He was also a patron of literature and took pride in being surrounded by men of letters. His court became the social centre of the nation and personal vanity and pride in the achievements of his race led him to support entertainments, when the opportunity offered itself, which should bear his fame to the boundaries of Portugal and to foreign lands as well.

Nothing, then, was lacking except the poet, and the poet appeared in the person of Gil Vicente whose genius was peculiarly suited to the composition of court entertainments. From I502 until 1536 Vicente was virtually poet-laureate. During the reign of Manuel, the majority of his plays were composed to commemorate religious festivals, but to this period also belong compositions like the splendid Exhortafao da guerra and Auto da fama, written in Portuguese and inspired by patriotic fervour, and some delightful comedies and farces. With the accession of John III to the throne in 1521 , the religious plays were not discontinued, but the 
festival entertainments acquired a more important place in the life of the court. From that time, Gil Vicente occupied the same position that was held by Ben Jonson a hundred years later at the court of James. A royal wedding, or betrothal or the birth of a prince or princess, or a royal entry, could only be celebrated fittingly by a play composed in honour of the occasion by the illustrious poet. Not only was he the author of these compositions, but stage-director and sometimes an actor as well. It is regrettable that documents have not been discovered that would permit us to visualize these splendid spectacles with a basis of fact, but the texts themselves furnish proof that these plays were presented with a magnificence that charmed the eye as well as the ear.

Limiting ourselves for the present to the festival plays, the Exhortafao da guerra, Auto da fama, Cortes de Jupiter and the Auto da festa are composed wholly or almost entirely in Portuguese, and therefore fall outside the limits of this study. The tragicomedy of the Fragoa d'Amor, in Castilian and Portuguese, was written to celebrate the betrothal of John III to Catherine of Castile, sister of the Emperor, in I524. Here the winning of the Infanta's heart is described as the conquest of a castle by Cupid, who in spite of its body-guard of Virtues, has succeeded in nailing in its centre the arms of Portugal. Venus then appears in search of her runaway Cupid, but her anxiety is relieved when she learns of the new laurels he has won in Spain. The scene is apparently derived from Sannazzaro's Farsa di Venere, che cerca il figliuola Amore, and recalls Ben Jonson's charming masque The Hue and Cry after Cupid.

A beautiful castle is then introduced and from one of its doors issue four gentlemen who represent Mercury, Jupiter, Saturn and the Sun, and four maidens. The four Planets construct a forge of Love which has the power to refashion man or woman, restoring youth to the aged and endowing the homely with beauty. A negro is the first applicant for treatment; he enters the forge and the Planets pound with their. 
hammers while the maidens sing. He comes forth completely white, but preserving, much to his disgust, his peculiar manner of spech. The crippled figure of Justice then presents herself, with crooked staff and broken scales. She wishes to be straightened and made anew before the new! Queen comes to Portugal. She proves to be a difficult case, and can only be refashioned when deprived of some of her. ill-gotten gains. The courage of the poet did not desert him even on occasions when flattery would have been more welcome than criticism. The next candidate is a friar who has had enough of monastic life and wishes to become a young gallant. With this change effected, the play ends with what seems to be a promise of a second part.

The Templo d'Apolo, written chiefly in Castilian, was performed at Almeirim in November, I526, to celebrate the betrothal of the Princess Isabel, sister of John III, to Charles $\mathrm{V}$, and her departure for Spain. The author apologizes in the prologue for certain imperfections in his work which he ascribes to illness, and narrates in burlesque form a vision he had had when he believed that death was imminent, a witty imitation of the Infierno de los enamorados theme. Apollo then appears and preaches a burlesque sermón de amores, which we shall see, was a prominent feature of many wedding plays. Various allegorical figures, dressed as pilgrims, are refused admittance to the Temple of Apollo by the door-keeper, but are finally received when they laud to the skies the glorious achievements of the Emperor and the virtues of the Princess.

The Nao d'Amores, written in Castilian and Portuguese, and performed at Lisbon in 1527 in honor of the newly-married Queen Catherine, is one of Gil Vicente's most delightful plays. There is real beauty in the romantic conception of the Prince of Normandy who must win the maiden Fortune in order to prove his love for Fame, the lady of his heart's desire, and who constructs a ship of Love, with Cupid as captain, to bear him on his quest. The boat is described with a wealth of symbolic imagery that recalls the craft that carried Jeoffroy 
Rudel to the Countess of Tripoli in Rostand's La Princesse lointaine. With its motley assortment of passengers who embark to seek Fortune, the Nao d'Amores may be regarded as a playful pendant to the Barca do Inferno, Barca do Purgatorio and Barca da Gloria.

The Comedia sobre a divisa da cidade de Coimbra, performed in that city in 1527 , proposes to explain in whimsical fashion the meaning of the coat-of-arms of Coimbra and the origin of local geographical names. Its fantastic plot is derived from the romances of chivalry, and as a humorous excursion into archæology, the play has points of contact with Sâ de Miranda's Fabula do Mondego. ${ }^{1}$ The Triumpho do Inverno, performed in 1529 in honor of the birth of the Infanta Isabel, presents with a rustic setting the familar Confictus veris et hiemis, and contains some popular lyrics of rare beauty.

The Auto da Lusitania, composed like the foregoing, in Castilian and Portuguese, was performed in 1532 in honor of the birth of Prince Manuel. This deals with the courtship of the maiden Lusitania by a Greek knight, Portugal, who finally wins her hand in spite of the pretensions of Mercury, whose suit is encouraged by Venus and other goddesses. The most interesting scene in the play is the interlude that shows two devils taking notes on the conversation between a rich merchant named Todo o Mundo and a poor fellow named Ninguem. Owing to these strange names, the devils gain an equally strange impression of the state of this world for they learn that Everybody seeks honour and Nobody seeks virtue, Everybody is praised and Nobody is reproved, Everybody seeks life and Nobody knows death, Everybody desires Paradise and Nobody pays his debts, etc. This jest is by no means original with Gil Vicente, for it is found in the ninth book of the Odyssey, in the English Nobody and Somebody, the French Aucun et Tout le Monde, the Castilian Entremes del Mundo

${ }^{1}$ Carolina Michaëlis de Vasconcellos, Notas Vicentinas. Gil Vicente em Bruxelas ou $O$ jubileu de Amor, Coimbra, 1912, p. 38. 
y No Nadie, Ulrich von Hutten's Nemo and in other medieval and Renaissance writers, ${ }^{1}$ but we must concede that he gave it an effective setting and handled it with skill.

From its very nature, the construction of the festival play was often loose. Occupying a middle place between the pageant and real drama, it depended for success upon scenic effects, music, songs and dances as well as upon the beauty of the lines. It contained more recitation than action or dramatic conflict. We cannot, therefore, judge Gil Vicente as a dramatist by his festival plays. In them we find wit, grace, good-taste and a charming lyrical note. It is in his comedies and farces that he displays his skill in dramatic construction, his keen powers of observation and broad human sympathy.

Both in the circumstances attending their performance and in subject matter, the pastoral and festival plays have much in common. The Spanish pastoral plays were entertainments for aristocratic audiences on the occasion of weddings or other festivity. They represented courtly traditions, and when rustic scenes were introduced, it was only to contrast the delicate sensibilities and polished speech of gentlefolk with the ignorance and rude language of shepherds.

The requesta de amores theme as presented by Encina, and the unhappy love of knight and lady (or shepherd and shepherdess) in the Egloga de tres pastores and Egloga de Placida $y$ Vitoriano, formed the basis for the subsequent development of the pastoral drama, and very few new elements were added before the time of Lope de Vega. The influènce of Encina is clear in the three pastoral plays of his contemporary, Lucas Fernández, published at Salamanca in I5I4. One of these, called simply Farsa o cuasi comedia, reproduces the rivalry between a knight and shepherd for a maiden's love that we find in Encina's first Egloga en requesta de amores. A young woman appears, protesting, like another Cefira or Plácida, that

${ }^{1}$ Carolina Michaëlis de Vasconcellos, op. cit., p. 86, and Rudolph Schevill, Cuatro palabras sobre "Nadie", Revista Critica hispanoamericana, vol. i, 1915, rp. 30-37. 
Fortune has separated her from her lover. She inquires of a shepherd whom she meets whether he has seen a knight in the neighborhood, but the fellow does not understand the meaning of caballero, and when she explains that it means courtier, he is not abashed and brazenly offers himself as a substitute. The hapless maiden, who expresses her feelings like a heroine of the romances of chivalry, declares that, like Dido, she will put an end to her life. The shepherd declares that Dido must have been a fool, and advises her to offer a reward for her lost love, for he had once recovered a donkey by such means. When he urges his suit in his rude way, the lady expresses surprise that even shepherds feel the wounds of Cupid, and he describes in rustic fashion the power of Love over all creatures. He suggests that she may find a refuge in his cabin, but she declares that she nrefers the grave. At this point the missing knight appears who makes short work of the shepherd and his pretensions, and the play ends with a song.

In this play the maiden is a gentlewoman, and the farcical element consists in the inability of a rude shepherd to share the refined feelings and to understand the conventional language of gentlefolk. In a number of later pastoral plays we find a lady similarly exposed to impertinent proposals from boorish shepherds.

Love among shepherds is again the subject of Fernández's Farsa o cuasi comedia del soldado. The shepherd Prabos is a victim of Love's cruelty. His flock roams at will and the pleasures of life have turned to bitterness. A soldier sympathetically offers him good advice, and then another shepherd, Pascual, appears and makes sport of his companion's trouble. He suggests a mixture of herbs that may cure him as they have relieved a sick donkey. The soldier resents Pascual's mocking tone, and explains the seriousness of Love's wounds according to the courtly conceptions of the time. He loses patience at Pascual's impertinent interruptions, and a sort of contrasto follows in which the shepherds declare that military service is only suited to idlers, 
rascals and thieves, while the soldier affirms that the army maintains justice and order, and proudly shows his Crusader's cross. Peace is finally restored and Pascual goes in search of Antona, Prabos's sweetheart, who after some hesitation accepts his hand. Pascual receives from each the promise of marriage and the play ends with a song in praise of Love. The mock-cermony in the last scene and the text of the song allow us to assume that this play was performed to celebrate a betrothal in the household of some nobleman. The allusions to certain plays of Encina, including the Egloga de tres pastores, prove that it was composed between 1509 and 1514 .

Fernández's Comedia de Bras-Gil y Beringuella, composed before the play above-mentioned, is the reductio ad absurdum, according to aristocratic standards, of the requesta de amores theme. Here all the characters belong to the peasant class. The shepherd Bras-Gil pays court to the shepherdess Beringuella, proposes marriage to her and is accepled as her betrothed. As they sing together a simple little lyric, Beringuella's grandfather, Juan-Benito, rudely breaks in upon their happiness, charging Bras-Gil with dishonorable intentions with respect to Beringuella. Bras-Gil indignantly denies the charge, and they are on the point of coming to blows when a peacemaker opportunely arrives in the person of Miguel-Turra, who proposes that Bras-Gil prove his sincerity by marrying Beringuella. Juan-Benito objects that the suitor is not the equal of his granddaughter in either family or fortune, and Bras-Gil replies with a farcical list of his relatives and acquaintances. Juan-Benito is satisfied with this evidence of respectability, and gives his consent to the wedding. MiguelTurra then asks about the maiden's dower, and her grandfather promises a formidable array of live-stock and household utensils. The bridegroom, on his part, promises a large number of articles of wearing apparel and adornment for the bride. The guests gather to celebrate the betrothal, and the play ends with a song and dance alluding to this happy event. Bras-Gil's courtship is conceived in a spirit of burlesque that 
must have diverted an audience of gentlemen and ladies, and the emphasis laid upon the recital of Bras-Gil's pedigree and upon the dowry and the bridegroom's presents allows us to assume that this interesting little composition was performed to celebrate a betrothal.

The Egloga de Torino, included in the anonymous Question de Amor, which was first published at Valencia in 1513 , forms a connecting link between the Spanish and Italian pastoral drama at the beginning of the sixteenth century. A bit of casuistry, later used by Garcilaso de la Vega in his first eclogue, gives its title to this novel, which has as background aristocratic society at Naples between the years I 508 and I5I2. The novel is hardly more than a description of the diversions and amusements of a group of persons whose identity has been fixed in many cases, and it is likely that the Egloga de Torino was performed before a future Queen of Poland, Bona Sforza, and other characters who appear in the novel. ${ }^{1}$

Torino mourns because his love for Benita (Bona Sforza) is not returned. After bidding a tender farewell to his flock, his rebec and staff, he attempts to take his life, since only in death can he find relief for his suffering. The shepherd Guillardo hears his groans and tries in vain to restore him to consciousness. His companion Quiral is more successful and inquires the cause of his trouble, making amusing conjectures. Torino replies that his malady is poca esperanza, but Guillardo still refuses to understand the nature of his disease. $\mathrm{He}$ thinks Love must be something like a basilisk, which he has heard, kills all those who see it. Benita then draws near and on hearing the subject of their discussion, bids Torino cease his importunities, but the lover declares that he is powerless to banish her from his thoughts. The eclogue closes with a villancico sung by the three shepherds.

Although this play was composed and probably performed

1 Benedetto Croce, $D i$ un antico romanzo spagnuolo, Archivio per le prozincie napoletane, vol. xix, I894, and Menéndez y Pelayo, Orígenes de la nozela, vol. i, Madrid, 1905. 
in Italy, it does not seem to owe much to Italian sources. It reproduces situations found in many Italian eclogues of the time, such as the unhappiness of a shepherd caused by unrequited love and the attempt at suicide, but these are already present in the Egloga de tres pastores of Encina, and the opening scenes in these two plays offer many similarities. From the same play is probably derived the use of coplas de arte mayor in the Egloga de Torino. The burlesque element in the pastoral, which even appeared in Poliziano's Orfeo, became popular in the early years of the sixteenth century, but we need not assign this element to Italian imitation since burlesque scenes are found in plays of Encina and Lucas. Fernández. The only feature of the Egloga de Torino that may with certainty be ascribed to Italian influence is the introduction of real persons as characters, a practice commonly found in the early Italian eclogues.

An anonymous Egloga pastoril proves that at an early date the plays of Encina were known and imitated at Valencia. Composed toward the end of 1519 or the early part of 1520 , it was probably performed to celebrate the escape of the city from the dangers of plague and from a threatened incursion of a Moorish fleet. The solemnity of the verses that describe the abandoned state of the city, which recall the famous coplas of Jorge Manrique, ill accords with the burlesque account of the grief of the shepherd Climentejo over the marriage of his sweetheart to a rival and the cure of his malady effected by the village encantador. The play is in many respects insignificant, but it is worthy of vote that the earliest extant example of the secular drama at Valencia borrowed its form, chief incidents, language and versification from a Castilian poet.

To approximately the same period belongs an Egloga mueva, attributed to Diego Durán, which represents with certain variations the conventional requesta de amores theme. A shepherdess, seeking her flock, meets a mendicant friar who compliments her on her beauty and offers her his love. She re- 
minds him of his holy calling, and he replies that those who carry on God's work are more often wounded by Cupid's arrows than anyone else. He becomes insistent, the maiden indignantly repels him and a taffy-vender opportunely intervenes. The latter offers his protection to the shepherdess, but agrees to play a game of cards with the mendicant and retires, stripped of all of his possessions.

Once more the mendicant prepares to assure himself of his victim when a friar intervenes who roundly abuses him for his wicked intention. In an unedifying scene, these two representatives of the Church accuse one another of gross misconduct, and finally the friar goes off to report his colleague's offence to the prior. Once again the maiden is in danger, but two shepherds appear who promise to punish the offender as he deserves. Thev agree to play a game, which ends with the complete discomfiture of the mendicant. The song which concludes the farce indicates Shrove Tuesday as the day of the performance. The original edition is undated, but its primitive character allows us to conjecture that it was probably composed about the year I520. The most striking feature of the play is the virulent satire of the morals of members of the clergy, which is also found in a number of other comedies and farces written in the first half of the sixteenth century. Apparently considerable latitude was allowed in the publication of works of this kind until the year 1559 when the first Index librorum prohibitorum was issued.

An Egloga of Juan de París of which the earliest known edition bears the date 1536 , combines the themes of Encina's Placida y Vitoriano and Cristino y Febea. Estacio, heartbroken over the disappearance of his sweetheart, Numida, whom he seeks in vain, determines to put an end to his life, but is persuaded by a hermit to banish love from his thoughts and to devote himself to the service of God. In the meantime, Numida is also seeking her lover and is accosted by a: shepherd, who is unable to understand the cause of her grief and proposes himself as a substitute for the missing Estacio. 
However, the shepherd is instrumental in re-uniting the lovers, and one glance at Numida suffices to cure Estacio of his desire to embrace the religious life. The play ends with a burlesque wedding ceremony performed by the shepherd.

Diego de Negueruela's Farsa llamada Ardamisa presents still another maiden wandering alone in search of her lover and exposed to all sorts of unpleasant encounters. With a conventional setting so well established, it required little imagination to add new characters. Here Ardamisa laments the indifference of Galirano, who has wearied of her own indifference, and calls upon death to ease her pain. She indignantly rejects the brutal proposals of a water-carrier, and later the ridiculous pretensions of an enamoured Portuguese. The latter is driven away by a bragging swashbuckler, who offers his protection in pompous phrases, boasting of the exploits he has already performed.

This illustrious descendant of Pyrgopolinices, however, does not offer his services disinterestedly, for he threatens to gain possession of the lady by violence. Her lover, Galirano, arrives in the nick of time, and the braggart, after a show of resistance, falls to the ground repeating the Creed. A friar then accosts the lovers and preaches them a sermon to prove that the salvation of their souls is endangered by their passion for one another. He suggests that Galirano enter a monastery and offers to conduct the lady to a place of safety. The offer is rejected, and the vanquished suitors then enter into a conspiracy to abduct the lady. As the conspirators stand before the house where the lovers have taken refuge, Ardamisa and Galirano come forth quite calmly, and bid farewell to the audience, and the play ends with a sword-dance.

Nothing is known concerning the author. The only early edition bears no date, but the play can be ascribed without question to the first half of the century. Judging from its primitive character, we may not be far wrong in assigning its composition to about the year 1530 . The love-sick Portuguese, the rufián cobarde and gipsy fortune-teller are stock 
figures in sixteenth-century comedy, and the shameless friar again indicates the popular attitude toward some of the religious orders.

The Farsa llamada Cornelia, only extant in an edition of I603, but almost certainly composed in the first half of the sixteenth century, shows a further deterioration of the requesta de amores. Preceded by a comic prologue after the manner of Torres Naharro, it describes the rude courtship of the shepherdess Cornelia by Benito, and the intervention of the latter and his companion to prevent the abduction of the girl by a rufián. From the standpoint of language and content, the play is without merit.

The requesta de amores theme, treated a lo divino, is found in the Coplas de una doncella y un pastor, said to have been printed as early as I530. A distraught maiden rejects the proposals of a shepherd who warns her that she will be eaten by a wild man (salvaje) if she remains alone. The wild man who interrupts this courtship proves to be a hermit who persuades the girl to cast aside all worldly thoughts and consecrate herself to the Virgin. The setting here is the same as in the above-mentioned plays, but the denouement is new.

The Spaniard's innate love of realism was responsible for the introduction of burlesque scenes as a foil to the extravagant declamation of many of the early pastoral plays, and in Diego Sánchez de Badajoz's Farsa de la hechicera we find a whole play devoted to the purpose of parody. A love-sick gallant calls upon death, in rhetorical fashion, to free him from his suffering. $\mathrm{He}$ is about to strike himself to the heart when courage and strength fail him, and he falls in a faint. $\mathrm{He}$ is found by a shepherd who places garlic in his mouth as first-aid treatment, and hurries off in search of a witch who is expert in the treatment of cramps. The ending of the play is highly diverting. The witch, finding that she has to deal with a more serious malady than cramps, draws a circle on the ground, scatters grain in the form of a cross and begins a conjuration that will kindle love in the heart of the 
lady whom the gallant adores. A devil appears in answer to the summons and is sent off to re-unite the lovers while the shepherd, very much frightened, takes refuge with the old woman inside the magic circle. $\mathrm{He}$ is finally carried off to prison by the magistrate on a false charge brought by the witch, and the spectator, or reader, is left in doubt as to the fate of the unhappy knight. This is a little masterpiece of keen satire and rollicking horseplay, and probably represents the attitude of an audience of tradespeople and peasants toward the artificialities of earlier pastoral plays.

A more ambitious treatment of conventional pastoral motives than hitherto attempted in Spain is found in the Comedia Florisea of Francisco de Avendaño, first published in $\mathrm{I} 55 \mathrm{I}$ and the earliest play that we possess divided into three jornadas. Here two unfortunates, Muerto and Floriseo, the one a victim of the cruel blows of Fortune and the other of unrequited love, determine to put an end to their lives, but this double suicide is averted by the arrival of a shepherd who makes sport of their laments. After the usual experiences that fall to the lot of young women traveling alone according to the conventions of pastoral plays, Blancaflor finds his missing Florisea, and a comic wedding ceremony, performed by the bobo, unites the lovers. Fortune appears opportunely to present the couple with a wedding-gift of a thousand ducats and to promise to provide abundantly for Muerto. The prologue and the comic scene between the shepherd and Fortune seem to be derived from Torres Naharro's Comedia Trofea, but in its general outline the play follows Encina's Egloga de Placida y Vitoriano and the Egloga of Juan de París.

The more formal type of dramatic eclogue is represented by the Comedia Tibalda of Per Alvarez de Ayllon, the date of which can only be conjectured from the fact that certain verses of its author were included in the I5I I edition of the Cancionero general of Hernando del Castillo. It was first printed in 1553 under the title Comedia de Preteo y Tibalda, with cer- 
tain additions by Luis Hurtado de Toledo. It was written in coplas de arte mayor, the measure used by Encina in his Egloga de tres pastores, with which it offers striking similarities in subject matter. The composition merely serves as a medium for the discussion of two questions that are frequently found in Spanish literature of the early sixteenth century, the remedies for the malady of Love, and the virtues and imperfections of women. For the first of these, the author is indebted to Ovid's Remedia amoris, while the inordinately long defense of women is copied almost literally from Juan Rodríguez del Padrón's Triunfo de las donas.

Luis Hurtado de Toledo not only attempted to compose a more satisfactory ending to the Comedia Tibalda, but also wrote another pastoral eclogue entitled Egloga Silviana del galardon de amor, published at Valladolid with the second edition of the Comedia Tibalda, the date of which is not known. The Egloga Silviana follows closely the incidents of the Egloga de Torino, and offers little of interest. Like the Comedia Tibalda, it should probably be classified as a nondramatic eclogue.

In the prologue to his Ocho comedias ( $16 \mathrm{I}_{5}$ ), Cervantes. writes that Lope de Rueda "was admirable in pastoral poetry, and in this respect was unsurpassed in his own time or thereafter". This praise is over-generous if we may judge from. the two artificial pastorals of Rueda that are extant. One of these, the Comedia llamada. Discordia $y$ question de amor is known only in an edition of the year 1617 , in which it is ascribed to Rueda. If he really be the author, it is reasonably certain that the division into three jornadas is the work of some arreglador to make it conform to the practice in vogue at the beginning of the sixteenth century. The play presents the same circle of unhappy lovers that is found in the sixth Idyl of Moschus, in the story of Selvagia of Montemayor's Diana, in Vicente's Auto pastoril portuguez and in several Italian plays, and which is familiar to all from its use in $A s$ You Like It. With this motive is combined the triumph of Chastity over Cupid. 
The other play of Lope de Rueda ${ }^{1}$ that follows the conventions of the artificial pastoral is the Coloquio llamado prendas de amor, published at Valencia by Timoneda in 1567. Two shepherds, Menandro and Simón, have received gifts from the shepherdess Cilena, and fall into a dispute as to which has obtained the greater mark of her affection. When they refer the question for decision to Cilena, the maiden replies by giving to each another present. This colloquy has no dramatic value, and was probably composed for the entertainment of some aristocratic gathering. Casuistical questions of this kind were frequently given literary form in Spain, and were probably introduced from Italy where similar $d u b b i$, casi and questioni were popular in courtly circles. Rueda was lacking in the poetic fancy that was required to redeem these trivial themes from banality. His power lay rather in portraying characters drawn from everyday life, and in reproducing in inimitable dialogue the popular speech of this day.

The earliest dramatic caso de amor in Spain is the anonymous Comedia Fenisa, first printed in 1540 . Three shepherds, enamoured of Fenisa, dispute as to which has received the greatest mark of her affection. Their pretensions are ridiculed by a bobo, who relates how Fenisa showed her interest in him by laying a mighty blow on his head with her crook. Finally the three rivals request Fenisa to express her preference. This play, in spite of its puerile simplicity, seems to have enjoyed unusual popularity. It was republished in

${ }^{1}$ In his comedia Los baños de Argel, printed in 1615 , Cervantes introduces a play performed by the captives and uses for this purpose a coloquio en verso by Lope de Rueda, of which thirty-five lines in quintillas are given. Although said to have been published by Timoneda, it does not form a part of any known work of Lope de Rueda. It has been suggested that these verses formed part of a coloquio of Rueda entitled Gila, of which Lope de Vega quotes two quintillas in the introduction to his Justa poetica de San Isidro (1621). See Comedias y ontremeses de Miguel de Cervantes Saavedra, edited by $\mathrm{R}$. Schevill and A. Bonilla y San Martín, vol. i, Madrid, 1915, p. 380 . 
1588 and 1625 , and forms the basis of two religious plays of the middle of the sixteenth century, the Coloquio de Fenisa and Fide Ypsa, in which the theme is treated a lo divino. It is likely that Juan de Melgar, to whom the version published in 1625 is attributed, is the arreglador and not the author.

The analogy is clear between the Comedia Fenisa and the various themes treated in the Italian $d u b b i$ and casi d'amore. In three plays of Timoneda, and in Alonso de la Vega's Comedia de la Duquesa de la Rosa, the representation of a caso de amor serves as a prologue. Two of these reproduce questioni d'amore derived from Boccaccio's Filocolo.

A return to the circle of unhappy lovers, treated by Lope de Rueda in his Discordia y question de Amor, is found in the Comedia Metamorfosea of Joaquín Romero de Cepeda, published in 1582, in four jornadas. Three shepherds and three shepherdesses suffer the pains of unrequited love and each blames another for heartlessness. Almost the entire play; is occupied with silly proposals, followed by brusque refusals. A metamorphosis takes place simultaneously in their hearts, and each shepherd or shepherdess expresses his or her love for the person who a moment before had been scorned. This change leads to as difficult a situation as the previous one, and the author, in despair of reaching a satisfactory conclusion, ends the play.

The Comedia Metamorfosea closes the list of pastoral plays composed in Spain in the period that antedates the dramatic activity of Lope de Vega. With the triumph of Italian comedy in the second half of the sixteenth century, the imitations of the Propalladia of Torres Naharro and the influence of classical and Italian tragedy, the Spanish drama enlarged its scope and was no longer content to repeat the commonplaces of Encina. The pastoral drama contained within itself the cause of its inevitable dissolution; it was not original and did not represent actual life. Imitative by its very nature, it could not thrive when the drama was no longer restricted to private performances at the palace of some grandee, but was 
forced to go out on the village square or into an improvised corral, to win the plaudits of the crowd. Audiences demanded at least an approximation to realism or some human interest, and this demand the pastoral drama failed to supply.

The passion of Philip IV for dramatic entertainments resulted in an active support of the court drama, and explains the revival of pastoral plays in the period of Lope de Vega and Calderón de la Barca. By that time, however, the traditions of the sixteenth-century drama were forgotten to a large degree, and Italian subjects, scenery and elaborate stage devices were in fashion. Except for the combination of recitation and song found in the works of Encina and some of his successors, there is almost a complete break in continuity between the sixteenth-century pastorals and compositions like La selva sin amor of Lope de Vega and Calderón's El pastor fido. 


\section{CHAPTER V}

\section{Romantic Comedy and the Comedy of Manners Before LOPE DE RUEDA}

Romantic comedy received its first impulse and its general direction for half a century from Bartolomé de Torres Naharro. Unfortunately we have only a few facts upon'which to base his biography. His family name was Naharro and he was born at the town of Torre de Miguel Sexmero near Badajoz. We know nothing of his education except that he shows an acquaintance with classical authors and that he knew Latin well enough to have written his plays in that language, according to the testimony of one of his friends. On one occasion, while traveling by sea, he suffered shipwreck, and to add to his misfortunes, he was captured by pirates and taken to Africa. We do not know the date of this, nor how long his captivity lasted. He obtained his ransom and arrived at Rome, probably about the year 1512. By that time he seems to have reached middle age. The knowledge that he shows of army life, particularly in the Comedia Soldadesca, allows us to assume that military service occupied some part of his youth. Two of his most inspired compositions are those addressed to the Great Captain, Gonsalvo de Córdoba and to the memory of another noted military leader, Pedro Manrique de Lara, who died in February, 15I5.

His residence in Rome brought with it bitter disappointments. Driven by poverty to seek patronage, he found that merit was not rewarded, and that rascals were successful while honest men starved. He obtained some sort of a post in the household of the turbulent Bernardino Carvajal, Cardinal of Santa Cruz, who belonged to a noble family of 
Plasencia and who had had the temerity to openly defy; Julius II. An amusing picture of some of the more humble retainers of one of his patrons is given in the Comedia Tinellaria which was performed, probably about the year I514, before a distinguished audience that included the Pope himself and also his cousin, Giulio de' Medici, who became Pope in 1523 under the name of Clement VII. His ability to provide entertainment for an aristocratic gathering was recognized at this time, for, as we know, he was chosen to write a play in honour of the Portuguese mission led by Tristao da Cunha.

We do not know when Naharro entered the service of Fabrizio Colonna, Grand Constable of Naples, and one of the leading generals of his time, but he speaks of him in grateful and affectionate terms in the preface to his volume of lyrical verse and plays, entitled Propalladia, published at Naples in 1517. At this time Naharro was living at Naples. The volume was dedicated to Fabrizio Colonna's son-in-law, Ferrante Francesco D'Avalos, Marquis of Pescara, who belonged to a family long distinguished in the annals of Spanish and Italian history. As the husband of Vittoria Colonna, and the object of some of her best verse, a serrimental interest still attaches itself to his name in spite of his infamous treason after the battle of Pavia. In a decree of Leo X granting to the author sole rights to the publication and sale of the Propalladia, Naharro is spoken of as a cleric of the diocese of Badajoz, but we do not know whether he entered the Church before or after his arrival in Rome.

Even more obscure are the facts of his later years. Two plays that were not included in the Propalladia were published after 1517 , one at Seville in 1520 , and the other at Seville in 1520 or at Naples in 1524 . We have no evidence that he ever. returned to Spain, and the date of his death is unknown.

$\mathrm{He}$ explains the meaning of Propalladia as "the first things of Pallas", but this does not mean that the compositions included in that volume are the fruits of his youth. Those that 
can be dated were written between 1512 and 1517 . As the first course (antipasto) of this intellectual feast, he serves forty-three short lyrical pieces. By far the most significant of these are the sátira and third capitulo in which, with rapierlike thrusts, he lays bare the seething corruption of Rome. Here he appears in the rôle of a stern moralist, which ill accords with the easy-going tolerance exhibited in plays like the Comedia Serafina. "Rome is a school for sin", he writes; "where no evil is left undone". "Reason and kindness are out of fashion; faith and love are dead." Only the dishonest triumph. "The world is their Paradise and money is their god". As a master of invective, Naharro has scarcely an equal in Castilian literature. The fact that the volume containing this bitter denunciation of ecclesiastical corruption was published with a letter from the Pope himself who speaks of the "elegant compositions" of his "beloved son" furnishes an interesting commentary on a certain kind of tolerance at Rome in the early years of the sixteenth century.

Next in order of merit are compositions, already referred to, in honor of Gonsalvo de Córdoba and Pedro Manrique de Lara, in which he gives expression to his ardent patriotism. His love poems are agreeable, but are lacking in warmth. In all of his verses, with the exception of three sonnets in Italian, he employs the traditional Spanish measures. In view of his acquaintance with Italian literature, it is perhaps surprising that he did not make the experiment of introducing the hendecasyllable into Castilian which was realized a decade later by Boscán.

In the Prohemio or prologue to the Propalladia, Torres Naharro initiates dramatic criticism in Spanish literature: After modestly stating his desire to publish in correct form his plays which were circulating in unauthorized versions, he refers briefly to his lyrical verses and then quotes a few opinions of the ancients concerning comedy. $\mathrm{He}$ distinguishes between comedy as the representation of civil and private fortune, without peril of life, as distinguished from tragedy, 
which occupies itself with heroic fortune in adversity, and cites Cicero's definition that comedy is "a copy of life, a mirror of custom and a reflection of truth". The poet Acron, to whom certain scholia on Horace were incorrectly ascribed, is mentioned as authority for a sixfold classification of comedies, and also for the four parts into which a comedy is divided. He agrees with Horace that the five-act division is necessary, and that decorum should be preserved.

Having thus paid his respects to classical authority, he proceeds to discuss comedy on the basis of his own judgment and experience. "Comedy", he writes, " is an ingenious arrangement of notable incidents, ending happily, and in dialogue". "The division into five acts not only seems to me good, but also very necessary, although I call them jornadas, because they seem to me more like resting-places than any thing else". Naharro was the first to use the word jornada as a substitute for act. Whether he invented the term or merely translated the Italian giornata, which was occasionally employed in this sense in the Italian sacre rappresentazioni, ${ }^{1}$ we cannot say. At all events, the claim made by Juan de la Cueva in his Exemplar poetico that he first used the word, is obviously incorrect.

A play should contain from six to twelve characters, he tells us, and propriety must be observed by assigning to each his proper place. He proposes an interesting classification of comedies, namely, the comedia a noticia, based upon something actually seen, and akin to our comedy of manners, and the comedia a fantasia, based upon fictitious material, but with an appearance of truth, and which may be translated romantic comedy.

Seven plays, namely, the Comedia Soldadesca, Comedia Tinellaria, Comedia Trofea, Comedia Serafina, Comedia Himenea, Comedia Jacinta and Dialogo del nascimiento, including the Adicion del dialogo, are contained in the volume entitled.

${ }^{1}$ A. L. Stiefel, Zeitschrift für vergleichende Literaturgeschichte, vol. v, I 892 , p. 487 . 
Propalladia, published at Naples in 1517 . The form of the titles is derived from Plautus. In the introito to the Comedia Tinellaria we are told that the title comes from tinelo as the Asinaria of Plautus from asinus.

Each of these plays is preceded by a prologue or introito which concludes in every case with a fairly detailed summary of the plot. The latter was necessary because dramatic art had not advanced far enough to present a series of scenes that would be intelligible to an audience without explanation. The prologue is recited by a rude shepherd who sometimes playfully greets his audience or expresses surprise on finding himself in such a distinguished gathering. His function is to entertain, and for this he resorts to broad farce. In some he relates with relish a lewd escapade, while in others he contents himself with narrating his accomplishments. He withdraws from the stage after reciting his lines and does not reappear.

The origin of this prologue is difficult to determine. Since the author was undoubtedly acquainted with classical comedy, it is natural to consider the prologues of Plautus and Terence as the source, as Menéndez y Pelayo and others have done, but this new form of prologue is more dramatic and more personal than its possible classical models. The term introito seems to lead us to the liturgical or religious drama, but the prologue as used by Naharro has little in common with the Anmunziazione recited by an angel in the sacre rappresentazioni. In considering the source, we must not forget that Encina's Placida y Vitoriano also contains a prologue recited by a shepherd, and that this play was in all probability written and performed in Italy. We know comparatively little concerning popular Italian comedies of the beginning of the sixteenth century, but it is an interesting fact that a number of the farces of Giovan Giorgio Alione contain a prologue called introito ${ }^{1}$ which has many points in common with those

${ }^{1}$ Stiefel, Literaturblatt für germanische und romanische Philologie, vol. xxiv, 1903, p. 126. 
written by Torres Naharro. It seems probable to me that the Spanish poet followed the example of both the classical and the religious drama of Italy in introducing some statement of the argument as a prologue, and then added a dramatic monologue consisting of humorous personal experiences which was probably a part of the repertory of the Spanish juglar and which developed in France into an independent genre. The burlesque references to details of the Church service, found in the prologues to the Comedia Serafina and Comedia Trofea, may indicate a relationship with the popular ceremony of the Boy Bishop.

It need cause no surprise that these plays, written in Spanish, should have been performed at Rome and Naples. Bernardino Carvajal, the author's patron in Rome, had Spanish affiliations, and Spanish ecclesiastics and diplomats, with their retinues, formed an important part of the exclusive society of Rome. In aristocratic circles at Naples, Spanish seems ta have been used as generally as Italian. The Dialogo del nascimiento, Comedia Soldadesca, Comedia Trofea and the Comedia Tinellaria were performed at Rome, and while we cannot be sure whether the other plays were presented in Rome or Naples, in either city an aristocratic audience could understand the plays of Torres Naharro as well as it could read the many Spanish books that were being published in Italy. In dealing with an audience that was practically bilingual, the author did not hesitate to introduce Italian characters speaking that language, and Catalan was also employed without apology or explanation in the Comedia Serafina. To add to this linguistic medley, maccaronic Latin, Portuguese, and an almost unintelligible French, were occasionally used for comic effect. It has been suggested that this use of two or more languages, which was fairly common in later Italian plays, was suggested to Naharro by the farces of Giovan Giorgio Alione, but it is difficult to explain how those compositions, composed in northern Italy, could have come to the attention of the Spanish dramatist at Rome or Naples. 
Aside from the date of publication of the Propalladia, we have little evidence to aid us in determining in what year these plays were written or performed, and their chronological order is likewise uncertain. Only the date of performance of the Comedia Trofea, already discussed, can be approximately established. We might assume that the Dialogo del nascimiento, which resembles in some respects the Christmas plays of Encina and Fernández, was written before Naharro went to Italy, but it shows an intimate acquaintance with Rome and on internal evidence can be dated after April, I5I2.

Among the first dramatic works of Torres Naharro, we may place the Comedia Tinellaria and Comedia Soldadesca, both of which were printed separately as well as in the Propalladia. Classified by their author as comedias a noticia, these present, without artifice or plot, a series of disconnected scenes designed to portray a certain social milieu. The suelta edition of the Comedia Tinellaria is dedicated to Bernardino Carvajal, the Cardinal of Santa Cruz, and in the prologue the author states that after the play had been performed before the Pope and Monseñor de Medicis, his patron, Carvajal had expressed a desire to see it, and then asked the author why he did not publish it. This statement is interesting since it shows that Giulio de' Medici had already shown some favor to the poet. The latter's relationship to Bernardino Carvajal also seems to be proved by a reference in the Comedia Soldadesca to an Andalusian soldier who was in the service of a chamberlain of Cardinal of Santa Cruz, and which is believed to be an allusion to Naharro himself.

Few documents of the period have greater historical and human interest than this picture of the tinelo or servants' dining-room of a Porporato. From the first scene, in which Barrabás, the chief steward, shows cynical disregard for his master's property and a desire to exploit him to the utmost for his own advantage, until the drunken orgy of the last act, we have an amazing picture of petty greed and maladministration. Not only does the good name of the cardinal suffer 
from the rapacity of his trusted officers. The true victims are the underlings, who are dependent for their sustenance upon the cardinal's bounty, and who are nearly starved by the wretched fare that is served to them. There is tragical intensity in the chorus of protests against the quality of food and wine that we find in the third act. When not complaining about the food, these petty servants quarrel over questions of national honour and dishonour in language that is far from parliamentary, and in one of the most amusing scenes a Portuguese, Andalusian, Valencian, Biscayan and Frenchman discuss, each in his own tongue, the relative merits of Lisbon, Seville, Valencia, Bilbao and Paris.

We can readily appreciate the virulence of this satire which was designed, we are informed in the prologue, to show the cardinals what actually went on in their kitchens. The chief figures must have been recognized by the audience, but unfortunately we have not sufficient evidence to identify them. We do not know who was the prototype of Barrabás, who rose in three years from the post of scullion to that of administrator of an important household. The figure is described with such bitterness that we may assume a personal grudge on the author's part. The identity of the Cardinal de San Iano is likewise uncertain. On several occasions during the play he is referred to as the next Pope, and since this prophecy was also made by Torres Naharro in one of his lyrical pieces regarding a cardinal who has been identified as Giulia de' Medici, it is possible that the future Clement VII, who actually witnessed the play, and whom the author mentions as his patron in the suelta edition, may have been pictured as the master of this infamous pack of rascals.

The Comedia Soldadesca has less dramatic interest. This presents a Spanish captain who is recruiting soldiers for the Pope's service. Some of those he enlists are veterans who have taken part, under Gonsalvo de Córdoba, in the famous victories at Cerignola and Garigliano (1503) and who have also fought at Bugia and Tripoli (I51O). Peace is irksome 
to them and they long for war "as do the poor for summer". They are joined by a poverty-stricken friar and others, who swagger about with lofty bearing as soon as they carry arms, and treat in a high-handed fashion an Italian tavern-keeper who is unable to understand their language. Many Italian plays contain the figure of the Spanish braggart soldier which, after making due allowance for national prejudice, serve to complement this picture given to us by Naharro. Allusions to the new break in relations of the Spanish king with the French, and the preparations of the Pope for war, seem ta refer to the invasion of northern Italy by Francis $I$ in the autumn of 1515 .

The Comedia Jacinta, probably the earliest of the comedias a fantasia, betrays the hand of a beginner. Three gentlemen, Jacinto, Precioso and Fenicio, disillusioned with life, have traveled from Germany, Rome and Spain, respectively, in search of adventures. They are stopped in turn by Pagano, a servant of a lady of great virtue and nobility named Divina, who persuades them to present themselves before his mistress. As they proceed to the lady's castle, they express their high admiration for women, attributing to them everything good in life. Divina receives the travelers courteously, listens sympathetically to the recital of their sufferings, and offers to accept one of them as a husband, and the other two as brothers. It is evident that the play has some allegorical significance, but whether it refers to some political event or was performed as a compliment to some lady here personified as Divina, is not known. It seems likely that in the person of Precioso the author voices his contempt for the corruption in manners at Rome.

The Comedia Serafina describes the predicament of the young Floristán on finding himself with two wives, a Valencian demi-mondaine named Serafina, and Orfea, an Italian lady whom he had married at his father's command. Serafina, accompanied by her maid Dorosía, follows her erring husband to Rome and upbraids him, in impassioned Catalan, 
for his infidelity. Floristán generously assumes all the blame, which is self-evident, renews to her his pledge of undying love and declares that either he or Orfea must die. After due consideration, he finally settles upon the latter alternative. $\mathrm{He}$ confides his purpose to the friar Teodoro, who cynically promises his aid, but insists that the lady must first have an opportunity to confess. Floristán tenderly explains to Orfea why her death is necessary, and she, like a dutiful wife, pardons her husband and prays to God for mercy. The dénouement is brought about by Teodoro's suggestion that since Orfea's marriage to Floristán had not been consummated, she might marry Policiano, Floristán's brother, who had returned quite opportunely to Rome, and who had long been in love with her.

We need not worry about moral considerations in this play which is merely, as Menédez y Pelayo suggested, a bufonada. There is real comedy in the contrast between the exalted sentimentality and abominable egoism of Floristán. The lackey, Lenicio, is one of the most successful portraits in Naharro's gallery of rogues. He possesses all the "social consciousness" of the later picaros. When his master Floristán accuses him of lukewarm attachment to his interests, Lenicio replies with uncommon frankness, "You masters still think that your servants are slaves. I never go to market without stopping at a brothel to leave what I have pilfered from you". Floristán asks helplessly whether he realizes the enormity of his sin, and Lenicio answers, "A servant is a fool who waits for his master to pay when he himself can collect his due". Teodoro, who advises so piously in maccaronic Latin, is a hypocrite of the same type as Fra Timoteo in Machiavelli's La Mandragola. In spite of defects in construction, this play is a good example of well-sustained farce.

In the Comedia Himenea, incidents that have become the commonplaces of romantic comedy made their first appearance on any stage. The infatuation of a gallant for a young lady, a first interview with musical accompaniment, the jealous 
watchfulness of the lady's brother who swears to avenge himself upon the betrayer of his honour, the rendezvous with the exchange of vows of undying love, brusquely interrupted by the brother, who after the momentary flight of the lover, demands the lady's life as a price of her dishonour, the lover's return and the offer of marriage which is accepted, these are the scenes that must have charmed by their novelty that first audience, and which even now delight us.

In presenting his characters, he makes effective use of contrast. The sentimental Himeneo, who melts to tears at the mere thought of Febea, has two servants, Eliso and Boreás, who are cynical regarding women and consider their master's passion a form of lunacy that permits them to extort additional pay. Himeneo fears nothing but a rebuff from his lady, while his servants boast mirhtily of their valour and leave their master in the lurch at the first sign of danger. Contrast is again the motive in the love-making scene between Boreás and Febea's maid Doresta, which playfully and in a lower key reproduces the incidents of the first interview of Himeneo and Febea, a situation that recurs in countless plays of the seventeenth century.

The argument of the Comedia Himenea is derived from the twelfth, fourteenth and fifteenth acts of the Comedia de Calisto $y$ Melibea. In both versions, the action is limited to twenty-four hours and except for the difference in the dénouement, the incidents agree in general outlines. Himeneo, like Calisto, is a sentimental, somewhat ingenuous lover; Febea and Melibea have the same charming simplicity of character that is capable of heroism when the occasion demands it; Eliso and Boreás correspond closely to Pármeno and Sempronio. With all these similarities, however, the play should not be regarded as merely a dramatization of a part of the Comedia de Calisto y Melibea. Naharro saw the dramatic possibilities of the central situation, added the character of Febea's brother, and portrayed in his own language that supremely interesting conflict of love and honour which anticipated 
by nearly a hundred years a situation frequently found in the comedia de capa y espada.

With the Comedia Aquilana, we are still in the world of romance. Aquilano, Prince of Hungary, disguised as a gardener, woos Felicina, a princess of the kingdom of Leon. $\mathrm{He}$ indignantly rejects his servant's suggestion that he make known his identity, because by his romantic code, the prize must be won by the ardour of his love, or not at all. One evening the princess grants him an interview in the garden, but as he unburdens his tortured soul of its secret, the princess hears a noise and brusquely dismisses him. The oversensitive Aquilano swoons and is found almost lifeless by two gardeners. He tells them that he is mortally ill, for Cupid has pierced his heart, and has made a wound that will never heal. The gardeners can understand nothing of this rhetoric, and make witty comments concerning his illness, and the madness of gentlemen on many occasions.

King Bermudo is alarmed over his serious condition, but the most celebrated doctors fail to diagnose the cause of his malady until one of them adopts the expedient employed in the case of Antiochus, as related by Plutarch, and discovers that Aquilano's pulse quickens at the sight of Felicina. When the king learns of this, he determines to put Aquilano to death, and Felicina contemplates suicide, but the prince's identity is established by his servant, and Bermudo gladly consents to the marriage of the young lovers.

The Comedia Aquilana was first printed, so far as we know, at Seville in 1520 , or at Naples in 1524 . The plot bears a slight resemblance to Gil Vicente's Comedia do viuvo, but the question of priority is difficult to settle, since the date of Vicente's play, while generally ascribed to the year 15I4, is disputed. A lover disguised as a gardener is also found in the Libro segundo de Palmerin de Oliva and in Vicente's tragicomedy of Dom Duardos. The Pietà d'Amore of Mariano Maniscalco has been suggested as a possible Italian source. The gardeners, who contribute the farcical element, 
closely resemble the shepherds of the pastoral plays. The Comedia Aquilana has good lyrical qualities, but lacks the sobriety and compact construction of the Comedia Himenea.

The Comedia Calamita more nearly approaches classical comedy than any other play of Torres Naharro, and also contains the best constructed plot. Young Floribundo falls madly in love with Calamita, a girl of apparently humble condition, thereby incurring the displeasure of Euticio, his father. Through the aid of his servant, Jusquino, Floribundo succeeds in entering the house of Calamita, declares to her his love, and readily agrees to the condition of marriage which she imposes. Euticio is very angry when he hears of what he considers his son's crowning act of folly, and threatens to take his life, but a solution is brought about by the discovery that Calamita is the long-lost daughter of a wealthy Sicilian gentleman and an old friend of Euticio. The sub-plot is made up of the marital difficulties of Torcazo, who is supposed to be Calamita's brother, and his wife Libina. Torcazo is an archfool who is unable to detect Libina's infidelities, but who can effectively employ a club to enforce his arguments with her. These two elements are well knit together, and the play gives. an impression of dramatic unity.

Complications arising from mistaken identity with the inevitable anagnorisis at the end are common in classical comedy, and the main plot bears a general resemblance to the Heautontimorumenos of Terence. Still closer is the analogy to Bartolomeo Zamberti's Latin play of the year ${ }^{504}$ entitled Comedia Dolotechne. Torcazo is the type of complacent husband, easily imposed upon by his wife and others, who appears so frequently in early Italian novelle and jest books. He offers. many points of resemblance with Boccaccio's Calandrino and with Martín de Villalba in Lope de Rueda's Tercer paso. Torcazo also recalls Calandro in La Calandria (1513) of Bernardo Dovizi da Bibbiena, and it has been pointed out that Jusquino's instructions to Torcazo how to feign death, in the fifth act of Calamita, are derived from the ninth scene of the 
second act of La Calandria. Two other scenes in the Calamita seem to prove the author's acquaintance with Cardinal Bibbiena's celebrated play. Since La Calandria was not published until 1521, and Calamita was probably printed in 1520, it is likely that Torres Naharro witnessed its performance in 1513 , and incorporated some of the incidents from memory into the Colamita.

We do not have sufficiently complete information concerning the Italian drama in the first years of the sixteenth century to accurately measure the extent of Naharro's indebtedness to Italian sources. There is no doubt that he was aware of the performances of Plautine plays in Italian at Ferrara and Florence. We nust remember, however, that the only regular Italian comedies written or perforned before 1520 were $L a$ Cossaria and I Suppositi of Ariosto, Cardinal Bibbiena's La Colondria and Machiavelli's Mandrogola. While we can readily estimate his obligations to these plays, the question of the influence of the popular farces and commedie rusticali, performed at Rome and Naples during the first two decades of the century, still awaits solution.

While Encina was the founder of the Spanish drama, Torres Naharro was Spain's first real dramatist. In place of the dainty triviality of Encina's pastoral eclogues and the rhetorical versified monologues of the Egloga de tres pastores and Egloga de Placida y Vitoriano, in which the protagonists studiously aroid one another through fear of terminating the play too soon. Niharro offers us a real human interest, a conflict of wills and. at times, a psychological development of character. Fimily honour, which was destined to furnish so many dramatic situations in the following century, made its first appearance on the stage in the Comedia Himenea. He did not disdain the use of farcical material, but his conception of comedy was more reflective and subtle than that of his predecessors. His lackeys are the very antithesis of the bobo. Keen-witted, sophisticated opportunists, they anticipate both Lazarillo de Tormes, and the gracioso of Lope de Vega. His 
dramatic work is uneven, but in the Comedia Himenea, Comedia Aquilana and Comedia Calamita, Spain had its first heroic comedies and comedias de capa y espada.

While it is unlikely that any play of Torres Naharro was performed in Spain, a number of editions of the Propalladia, unexpurgated and expurgated, and imitations, especially during the first lalf of the sixteenth century, prove that his plays were known in his native country. These imitations may easily be recognized by their division into five jornadas, their composition in coplas de pie quebrado, their use of a comic prologue, and by subject matter derived directly or indirectly from the Comedia Himenea or the Celestina.

The two latter compositions ${ }^{2}$ are responsible for what little inspiration is found in the two plays of Jaime de Güete or Hucte, entitled Comedia Tesorina and Comedia Vidriana. Of the first, we have only an undated suelta and an edition of $155 \mathrm{I}$, and of the second only an undated suelta. Nothing is known of the author, save that he was an Aragonese, a fact which is evident from his language. Both plays are written in five acts, in coplas de pie quebrado, and are preceded by a comic prologue in the manner of Naharro. The Comedia Tesorina presents the wooing of Lucina by Tesorino, who by a clever ruse, gains access to her house and then secures the services of Fray Vegecio to unite them in marriage. The friar's lisping speech adds a touch of humor to the ceremony, which ends in a witty sermon de amores. The anxiety of Timbreo over his daughter's disappearance is somewhat relieved by Vegecio's explanation, and he is finally reconciled to the marriage. Tesorino is an insipid Himeneo; Lucina shows no trace of Febea's innate delicacy; Pinedo is a dull-witted Boreís, and Vegecio recalls the friar of the Comedia Serafina. The feminine counterpart of the bobo appears in the indolent and saucy Citeria. A negress also appears in the fifth act

'Menéndez y Pelayo, Orígenes de la novela, vol, iii, p. cxlviii, mentions an anonymous Comedia Clariana, published in 1522, which appears from the rubric to be based upon material taken from the Celestinu. 
for the purpose of creating dramatic suspense by her incoherent account to Timbreo of his daughter's elopement, a figure frequently employed for the same purpose by Lope de Rueda. The play may be regarded as an unintelligent imitation of the Comedia Himenea, with which it has a few verbal similarities.

The Comedia Vidriana has hardly a redeeming quality. The author adopts the chief incidents of the Celestina, omitting the figures of the bawd and her infamous associates, but is plainly embarrassed in giving to these scenes dramatic unity. New characters are introduced at random, and farcical scenes are added that have no organic relationship to the main plot. The consuming passion of Calisto becomes commonplace in Vidriano's love-making, and the keen wit of Calisto's servants degenerates into buffoonery. As a substitute for the tragic dénouement of the Celestina, we have Vidriano's attempt to abduct Leriana which is frustrated by the lady's father. Vidriano makes a lame excuse for his rash act and makes an offer of marriage to Leriana, which is acceptable to her parents.

The Comedia Radiana of Agustin Ortiz, also composed in five acts of coplas de pie quebrado, and probably written between the years 1533 and $1535,{ }^{1}$ again shows the influence of the Comedia Himenea. Through the aid of his servant Turpino, Cleriano secures an audience with Radiana, who accepts his love with incredible facility. The escape of the lovers is prevented by Lireo, Radiana's father, who swears to avenge the injury to his honour by taking their lives. A priest arrives from nowhere, who counsels moderation and obtains the consent of Lireo to the marriage ceremony which is straightway performed. The chief merit of the play is its brevity. The first act consists entirely of Lireo's laments for the death of his wife, probably suggested by the opening scene of Vicente's Comedia do viuvo, and apparently was introduced for the sole purpose of explaining the absence of Radiana's mother. The

1 R. E. House, Modern Philology, vol. vii, I910, p. 509. 
heroine does not appear until the fifth act, and there are a number of farcical scenes that have not the remotest connection with the rest of the play. Its editor has pointed out a few verbal similarities with the Comedia Himenea. ${ }^{2}$

The influence of Encina, as well as that of the Celestina and of Naharro, is evident in the Comedia Tidea of Francisco de las Natas, a cleric of the diocese of Burgos. The only edition known is of the year I550, but the date of its composition is probably considerably earlier since its author published a translation of the second book of the Aeneid in I 528, and an unextant Comedia Claudiana in 1536 . The loveaffairs of Tideo and Faustina follow closely those of Calisto and Melibea, and Celestina herself plays a prominent rôle in the person of Beroe. Tideo employs the same rhetorical language as Vitoriano in Encina's eclogue, and an interlude in the second act recalls the Aucto del repelon. The dénouement brought about by the discovery that Tideo is a prince in disguise, may indicate an acquaintance with the Comedia Aquilana. The play contains a considerable amount of coarseness and irreverence which ill accords with the author's profession, and which probably was responsible for its appearance upon the Index of 1559 and of $\mathrm{I}_{583}$. By reason of its harmonious arrangement of scenes, natural development of the action and lively dialogue, we may regard it as the best of the series of imitations of the Celestina and the Comedia Himenea.

In the anonymous Far c $_{\text {a }}$ a manera de tragedia, printed at Valencia in 1537 , the tragical consequences of love are presented. We are told in the prologue that the play is based upon an actual occurrence, and the author is successful in portraying vividly the ardent passion of Torcato for Liria, and her timid acceptance of his love. But their golden dreams of happiness are frustrated by 'Carlino, Liria's brother, who spies upon her movements and convinces himself of her in-

${ }^{1}$ Menéndez y Pelayo, Origenes de la novela, vol. iii, p. cxlix, mentioned a Comedia Rosabella (1550) by Martín de Santander which, from the rubric, appears to resemble somewhat the Comedia Radiana. 
fidelity. Her husband, the complacent Gazardo, refuses to give credence to Carlino's charges, but finally consents to set a trap for her in the form of a forged letter. When Torcato receives this letter, apparently signed by Liria, in which she tells him that the secret of their relations has been discovered and that she no longer cares for him, his joy is turned to despair. With his own blood, he writes Liria a letter, blaming herself for his death, and stabs himself. Liria receives the missive, finds the body of Torcato, and kills herself after lamenting his death and his lack of faith.

The influence of Torres Naharro is evident in the division of the play into five acts, and the passion of the two lovers, thwarted by the lady's brother, recalls the Comedia Himenea. The stupid husband, who does not deserve Liria's love, and is unable to perceive her infidelity, recalls Torcazo in the Comedia Calamita. At the same time, the double suicide resembles the Egloga de Placida y Vitoriano. The opening scene has considerable poetic beauty, and the death of Torcato and Liria is portrayed with genuine feeling. Although the protagonists often express themselves in the conventional style of the sentimental novels of the day, the play has a real human interest.

There is no reason to dispute the opinion of its learned editor that the Auto de Clorindo is as "execrable as can be imagined". In the opinion of Gayangos, the single extant edition was printed at Toledo in $1535 .^{1}$ The rubric bears the statement, "sacado de las obras del Captivo por Antonio Diez, librero sordo, y en partes añadido y enmendado". We have no means of establishing the identity of "el Captivo", nor of determining the additions made by the "deaf bookseller". The play is written in three acts. Here we have, not one gallant, but two, who are in love with step-sisters. After various incidents without interest, silly shepherds' scenes and incantations, the lovers succeed in abducting the young women from a con-

1 If this date is correct, the Auto de Clorindo is the earliest Spanish play in three acts. 
vent. It is doubtful whether the Spanish drama includes another play more completely devoid of literary merit.

We have abundant documentary evidence that throughout the Middle Ages weddings were occasions of merrymaking, and that the attendance of juglares was regarded as indispensable. We read, for example, in the Primera cronica general, that at the marriage of the daughters of the Cid to the infantes of Carrion, there were many juglares and all the other diversions that pertain to weddings. Many allusions to this practice also occur in the plays of Encina, Fernández and Vicente. The Marquis of Santillana mentions in his wellknown Prohemio the "songs that are sung at weddings in praise of the bride and groom " and we seem to have a clue to the nature of these songs in a composition of Encina, included in the Cancionero musical, ${ }^{1}$ which from all appearances was written for some wedding. It is written in dialogue form, and contains a reference to the bride's pedigree, a list of the objects that constitute her dower and a list of the groom's presents. Apparently these wedding festivities were accompanied by considerable license, for a decree of the Council of Lugo (572) prohibited members of the clergy from witnessing "aliqua spectacula in nuptiis vel conviviis", and this order was repeated by countless subsequent Councils. A number of Spanish plays of the first half of the sixteenth century contain as prominent elements the pedigree of a bride and bridegroom, a list of objects that constitute the bride's dower and the groom's presents, a marriage ceremony that is usually performed with burlesque features, and a wedding song at the end. The nature of this material allows us to assume that such plays were performed at weddings. ${ }^{2}$

The earliest extant play of this type, and also the most complete, is the Egloga interlocutoria of Diego de Avila, printed before 1512 . Here is described the betrothal and marriage

${ }^{1}$ Cancionero musical de los siglos XV y XVI, Madrid, 189o, no. 383 .

'J. P. W. Crawford, Early Spanish Wedding Plays, Romanic Review, vol. xii, I92I. 
of a peasant youth, Tenorio, to Teresa Turpina, a country maiden, through the mediation of Alonso Benito, a professional match-maker (casamentero). The latter recites a comic pedigree of the girl and a long list of articles that make up her dower. Tenorio's father is not outdone in generosity and promises in his son's behalf an equally long list of gifts. Both parties are satisfied, and a priest, accompanied by a sacristan, performs a burlesque marriage ceremony. This diverting farce is dedicated to Gonsalvo de Córdoba, and must have amused some aristocratic gathering on the occasion of a wedding.

The Farsa de Costanza ( I 522) by Cristóbal de Castillejo, may probably also be classified as a wedding play. For a study of this we are dependent upon an analysis of the plot and a few extracts made by Moratín from the original manuscript before its disappearance in the year 1823 . The play consisted of seven acts, preceded by a prologue in Latin recited by the god Hymen. Two married couples air their domestic grievances in exceedingly coarse language, and finally the husbands agree to exchange wives. A friar preaches a burlesque sermón de amores, and in the last act a priest pronounces the former marriages void and re-weds the two couples according to the terms of the exchange.

The Farsa del matrimonio of Diego Sánchez de Badajoz specifically bears the rubric "para representar en bodas". The shepherd who recites the prologue makes a burlesque defense of marriage which is comparable in many respects with Castillejo's Sermon de amores. This is followed by a bitter dispute between a husband and wife regarding the relative superiority of man and woman, which is finally decided in favour of man by a friar who acts as referee. The friar then conceives the idea of marrying his servant to Menga, daughter of the disputants, in the belief that he alone will profit by the arrangement. After the ceremony is performed and the intentions of the friar are discovered, his summary punishment is described with brutal realism. Clerical satire could scarcely 
be more virulent. This play was included in the volume entitled Recopilacion en metro, and was also published in a suelta edition at Medina del Campo in 1603.

Gil Vicente's delightful Comedia do viuvo, written entirely in Castilian, and probably performed in $15 \mathrm{I} 4$, is a wedding play of an entirely different type. A widower mourns the death of his wife, and neither finds comfort in the sympathetic words of a friar, nor in the jests of a friend who is unable to rid himself of a shrewish mate. A young nobleman, named Rosvel, falls in love with the widower's two daughters, Paula and Melicia, and obtains from him employment as a workman. From this point of vantage he courts the young women. $\mathrm{He}$ wishes to marry one of them, but both are so charming that he is unable to express a preference. This embarrassing question is submitted to the young Prince John, who was a spectator, and who decides that Rosvel shall marry Paula. Gilberto, Rosvel's brother, arrives opportunely, and wins the hand of Melicia. The father consents with some reluctance to the betrothal of his daughters, and a priest enters who performs the marriage ceremony. This is followed by a brief sermon in which the newly-married couples are reminded of the origin of marriage and the Scriptural injunction to "increase and multiply". It is a work of real beauty, surpassed by no Spanish play of the first half of the century in poetic charm.

Gil Vicente realized, as no Castilian writer of his time, the dramatic value of the material presented in the romances of chivalry. The idealization of love and personal courage with its romantic setting was peculiarly appropriate for representation before a Court whose social code had been moulded by traditions of knighthood, and in this world of fancy Vicente's poetic imagination found free expression. In Dom Duardos ( 1525$)$, written entirely in Castilian, he dramatized a portion of the second book of the Palmerin de Oliva series. Don Duardos, Prince of England, becomes enamoured of Flérida, daughter of Emperor Palmerín of Constantinople while engaged in combat at her father's court, but does not disclose 
his identity. After many adventures, he returns to the Emperor's court and secures employment as gardener, so that he may have an opportunity to see and speak with the Princess. His ardent love, couched in poetic language, awakens in the heart of Flérida an uncommon interest, which is transformed into real affection after she drinks from an enchanted cup presented to her by Don Duardos. In vain she calls upon him to declare his identity, fearful of bestowing her affection upon an unworthy object, but he romantically prefers to obtain her favour with the sacrifice that his humble station seems to involve. Finally they embark together into the great unknown. A sort of comic interlude which treats of the appearance of Camilote and Maimonda at the court of the Emperor shows the author's critical spirit with a tendency to burlesque, in handling his material; but aside from this incident, he deals with it sympathetically and surrounds his characters with a poetic atmosphere.

Vicente's Amadis de Gaula, performed in 1533, has far less interest. This deals with the well-known incident of the retirement of Amadis from the world as a consequence of a letter from Oriana, charging him with insincerity. The grief of Amadis is too extravagant to awaken our pity, and we are not quite sure whether this picture of the hermit-knight was drawn in a serious or mocking mood. At all events, hairsplitting casuistry replaces the tender passion of Don Duardos, and the plot is loosely constructed.

Vicente's last play, the Floresta de enganos, performed in 1536 and written in Portuguese and Castilian, is a bizarre composition. Preceded by an ingenious prologue in dialogue form, it presents a series of deceptions and tricks with little relationship to one another. Two of these, the trick played, by a youth upon a merchant who tried to deceive him, and the discomfiture of an unscrupulous officer of justice, are conceived in the same spirit as some of Lope de Rueda's pasos.

Among the farces of Gil Vicente, we are here concerned only with the Farga das ciganas (probably 1525), written en- 
tirely in Spanish, and the Farfa dos fisicos, which contains a considerable amount of Castilian. The former is a brief composition without dramatic interest, presenting four gipsy girls who announce to imaginary clients their skill in fortunetelling, and four gipsy men who in like manner, offer their services as horse-traders. The latter is an exceedingly witty satire of the medical profession and of the lax morals of certain members of the clergy. Four doctors, prominent figures at Court, are called in to attend a priest and make as many diagnoses concerning the cause of his illness, without realizing that he has been brought to death's door by the curt refusal of a woman to accept his love. $\mathrm{He}$ confesses the truth to a friar, who reproaches him only for lack of patience, and comforts him by declaring that he is merely obeying the Divine command to Adam that for woman, man shall forsake all. This little play is a masterpiece of cynical humour.

The Farsa Salamantina of Bartolomé Palau presents once more the familiar incidents of the Comedia Himenea and its imitations with one important difference, namely, that the sentimental lover here appears as a picaro, and the romantic passion of Himeneo degenerates into a sordid abduction with robbery as the motive. There is no contrast here between sentimentality and common sense, since both master and servant are anti-heroes and have the same ethical code, or the lack of one. Most of the incidents might readily form a chapter of a picaresque novel.

The form of the play-five jornadas and coplas de pie quebrado-recalls Torres Naharro and his imitators, and in a few scenes the author shows unmistakable acquaintance with Jaime de Güete's Comedia Tesorina. The background of student life at Salamanca, with its discomforts, is vividly portrayed, and there is interesting criticism of the contemporaneous standards of justice in the lackey's description of the harsh treatment accorded to servants. The only old edition known is of the year I552, but since the author refers to himself in the rubric as "a student of Burbáguena", it is likely that it 
was written at approximately the same time as Palau's first play, the Farsa llamada custodia del hombre, which was composed between 1540 and 1547 . Five episodes in the play, which have little connection with the action, recall Lope de Rueda's use of the paso, and seem to indicate an acquaintance with the plays of his illustrious contemporary. It has been conjectured that Lope de Rueda referred to Palau in describing the Licentiate Jáquima in his paso entitled El convidado.

The Comedia Prodiga of Luis de Miranda, published at Seville in 1554 , and possibly written shortly after $1532,{ }^{1}$ presents in seven acts the Parable of the Prodigal Son, a favorite subject for School Dramas throughout Western Europe during the Renaissance. The author expressly states his desire to show young men the wages of $\sin$ and dissolute conduct, and while we should not question his sincerity, it must be admitted that he describes with relish Pródigo's downfall. A victim of thievish parasites and unscrupulous harlots, the youth is speedily reduced to poverty and repentance, and returns to his father, richer only in experience. The author is skillful in presenting these picaresque characters, who were undoubtedly suggested by the Celestina, and the play has considerable human interest.

${ }^{1}$ Cañete, Teatro español del siglo XVI, p. I22. 


\section{CHAPTER VI}

\section{Lope de Rueda, Italianate Comedy and the Farce}

In the prologue to his volume entitled Ocho comedias (16I5), Cervantes writes enthusiastically of his youthful recollections of the plays of Lope de Rueda. "He was a native of Seville", says Cervantes, "and a gold-beater by trade. He was a marvel in pastoral poetry, and in that style, neither in his own day nor since, has he been surpassed by any one. I was only a boy then, and could not form a reliable judgment of the merit of his verses, but now, at my mature age, I have read some of the lines that remained in my memory and I find that what I have said is true. If it were not out of place to do so in this prologue, I should quote here some lines that confirm my statement". After giving us valuable information concerning the staging of Rueda's plays, Cervantes continues: "Lope de Rueda died at Cordoba, and because he was an excellent and famous man, they buried him in the cathedral of that city between the two choirs".

Recent investigations have contributed a few additional facts to his biography. We do not know when Rueda adopted the profession of actor, but by $155 \mathrm{I}$ he had become a professional actor-manager, the first of which we have any record in Spain. In I554 his company performed a religious play at Benavente ( $a$ town between Zamora and Astorga) as a part of the festivities organized by Don Antonio Alonso Pimentel, Count of Benavente, in honor of Philip II who was en route to England. From I554 to I557, Rueda was living at Valladolid with his wife Mariana, a strolling singer and dancer, as appears from the court records of a suit brought by him against the heir of Don Gaston de la Cerda, Duke of Medinaceli, for 
services rendered by Mariana from 1546 to $155^{2}$. In 1558 we find him performing una gustosa comedia at the dedication of the new Cathedral of Segovia, and the following year his company presented two autos entitled El hijo prodigo and Navalcarmelo at the Corpus festival at Seville.

$\mathrm{He}$ is said to have performed Corpus plays at Toledo in 1561, and we find him in the same year living at Madrid where he received payments from the Royal Treasury for two plays presented at the instance of the Queen. It was probably in this year that 'Cervantes witnessed one or more of Rueda's performances. The sojourn in Madrid was not financially profitable and in the latter part of $156 \mathrm{I}$, the actor-manager left for Valencia, the native city of Rafaela Angela Trilles, his second wife. We do not know how long he remained in Valencia, where some of his plays were undoubtedly performed, nor do we know in what year he went to Cordoba, where he died, probably, in 1565 .

The rise of travelling theatrical companies in Spain about the middle of the sixteenth century is a fact of great importance in the development of the drama. Previous to that time there had been actors in Spain, but they were attached for the most part to the household of a nobleman. This meant that their performances were limited to private representations, that plays became generally known only in printed form, and that the type of plays was more or less dictated by the taste of wealthy patrons. The earliest reference to professional actors in Spain is found in an edict promulgated by Charles V in 1534 against extravagance in dress, in which it is stated that the same restrictions apply to "los comediantes, hombres $y$ mugeres, musicos $y$ las demas personas que asisten en las comedias" as to other persons. This ill accords with the statement of Cervantes concerning the meager stage properties employed by Rueda, and we may assume that the decree had in view court entertainments rather than the popular performances of the day. Theatres were, of course, unknown, and Rueda, apparently, was willing to play whenever an audience could be collected in some square or yard. 
It is unfortunate that we do not possess the original text of Lope de Rueda's plays. These were published two years after the author's death, in 1567 , by the Valencian playwright and bookseller, Juan de Timoneda, who states in the preface of the Comedia Eufemia and Comedia Armelina that he had changed certain portions of the original manuscript before soliciting permission to print, omitting "algunas cosas na licitas y mal sonantes, que algunos en vida de Lope habran oido", and in the prologue to the Comedia de los engañados and Comedia Medora, he complains of the labor involved in making many corrections in the original text. We have no means of determining whether the editor limited himself to changes of minor importance, or whether he actually attempted to rewrite the plays.

We have not sufficient evidence to assign dates to the composition of these four comedies, nor even to determine their chronological order. Because of its faulty construction and lack of originality, Stiefel gave first place in point of time to the Comedia Medora. Here Rueda made free use of $L a$ Zingana (or Cingana), by the poet-painter Gigio Arthemio Giancarli, which was first published at Mantua in 1545 or 1546. This play which is one of the most curious dialectal comedies of the Cinquecento, combines elements derived from classical sources and from the commedia rusticale. The plot turns, as in the Menaechmi and La Calandria, on the resemblance of twins, a boy and a girl, and the identification finally effected by a gipsy woman who had stolen the boy from his cradle. The play seems to have enjoyed unusual popularity in Italy and its influence upon a number of later compositions has been noted. Rueda retained the chief incidents of his Italian original, but omitted many scenes of secondary importance, thereby greatly reducing its length, and added four new characters, the rufianes Peñalva and Logroño, the simple Ortega and the page Perico. He also gave increased importance to the braggart Gargullo, a rôle in which he himself excelled, and he invented a few comic scenes which may be classified as pasos. 
Two cases of mistaken identity, which recall the plots of two Italian plays, II Servigiale of Giovan Maria Cecchi and Altilia of Anton Francesco Raineri, form the basis of the Comedia Armelina. The anagnorisis is brought about by Neptune who, after saving Armelina from a misalliance with a shoemaker, restores to one father a long-lost daughter and to another a long-lost son. Whatever may be the debt of Lope de Rueda to the above-mentioned Italian dramatists, or to a common original, the play is redeemed from utter absurdity by a few comic scenes that are undoubtedly his own invention. Lope de Vega had this play in mind when he wrote in El arte nuevo de hacer comedias of the prose comedies of Rueda which introduced tradespeople and the love-affair of a smith's daughter.

In writing Los engañados, Rueda made a free version of the anonymous Gl'Ingannati, one of the best Italian comedies. of the Cinquecento, and first performed by the Intronati of Siena in I53I. Gl'Ingannati was first published at Venice in 1537 , and its success is attested by no less than twenty editions; by its translation into Latin by Juan Pérez with the title Decepti (1574) and an anonymous Latin translation made in England about twenty years later with the title Laelia, and by the fact that it was the direct or indirect source of Twelfth Night, Charles Estienne's Les Abusez and La española de Florencia of Calderón de la Barca or Lope de Vega.

For the five acts of Gl'Ingannati, he substituted a division into ten scenes. Finding his Italian original too long for his purpose, he suppressed many relatively unimportant incidents and concentrated the interest upon the love of the girl-page Lelia for Lauro, and the complications arising from the resemblance between Lelia and her brother, Fabricio. Certain scenes were omitted in the interest of decency, while the comic elements with the bobos Pajares and Salamanca, and the negress Guiomar as the chief characters, are almost entirely original. In his adaptation, Rueda showed himself a good judge of dramatic values, but the play, while interesting, does. 
not rise above the level of an ingenious comedy of intrigue. It is obviously unfair to compare Rueda with Shakespeare, but it is nevertheless true that Los engañados would give us more enjoyment if Trelfth Night had not been written. The incidents are sufficiently similar for us to expect Viola and the Duke when it is only Lelia and Lauro, and Rueda's clowns are poor substitutes for Sir Toby and Sir Andrew. Los en gañados presents a few romantic situations, but is devoid of the saving grace of poetic fancy.

Greater originality is shown in the composition of Eufemia which, like Cymbeline, is ultimately derived from the ninth story of the second Day of the Decameron. In the latter version, the testing of a woman's virtue and the false charge brought against her is the result of a wager, while in Rueda's play, jealousy is the motive for the attempt to discredit the heroine. In Eufemia, the protagonists are a brother and sister, and in the Decameron, a husband and wife. The wanderings of the outraged wife, which occupy so important a place in Boccaccio's version, do not appear in Rueda's play, and the denouement is entirely different. There are few scenes in the early Spanish drama more compelling that that in: which Eufemia confronts her traducer and ingeniously extorts from him an acknowledgment of her innocence. The play has in common with the story of the Decameron little besides the manner in which the false evidence is obtained. Until the contrary is proved, the other incidents must be regarded as Rueda's own invention. The fifteenth patraña of Timoneda's Patrañuelo, published a year after Rueda's death, contains another version of the story, which shows more analogy with the Decameron than with Eufemia.

Two pastoral colloquies of Lope de Rueda, published together with the four comedies by Timoneda in 1567, have only a superficial relationship with the conventions of the earlier pastoral drama. The first scenes of the Coloquio de Camila attempt to reproduce the artificial pastoral setting of Sannazzaro's Arcadia or the Diana of Montemayor, but the 
plot repeats, with few changes, the incidents of the Comedia Armelina. In the Coloquio de Tymbria, disenchantments alter so frequently the identity and sex of the principal characters that the patient reader reaches the dénouement with patience exhausted. Rueda is absurd when he essays elevated language or fanciful material, and the play is only redeemed by a few excellent farcical scenes.

In order to properly understand his dramatic work, we must realize that he looked upon plays solely from the point of view of an actor and manager, and that he regarded of prime importance the entertainment of an audience that might assemble on the village square or in some inn-yard. Under these circumstances, the conventional pastorals and the refined subtilties of Torres Naharro, composed for representation before gentlefolk, were unsuited to his purpose. He knew that comedy of intrigue with romantic incidents, interspersed with farcical scenes and horse-play, would please, and he found some of these elements in the Italian comedy of his time. We know that a certain Muzio, with a company of Italian players, took part in the Corpus festival at Seville in 1538 , and that one of Ariosto's comedies was performed at Valladolid in 1548 , presumably by an Italian company, on the occasion of the marriage of the Infanta Maria, daughter of Charles V., to Maximilian, Prince of Hungary. Also, some time between 1556 and 1559 , or before, Antonio Vignali of Siena, a member of the Accademia degli Intronati, presented plays at the court of Philip II. In view of these facts, it is reasonable to suppose that Rueda became acquainted with Italian plays through the repertory of some itinerant Italian troupe. At all events, he wrote as a professional playwright, with more consideration for the requirements of his audience than care in interpreting faithfully his original. $\mathrm{He}$ realized, too, that humor is essentially local in its appeal, and he usually replaced comic scenes in the Italian plays that he recast by others of his own invention. It is particularly in these scenes that he shows a mastery of dialogue and a know- 
ledge of the resources of popular speech unsurpassed in Spain in the sixteenth century.

As Torres Naharro occupies first place in the drama in the first half of the century, Lope de Rueda is the dominant figure among the playwrights about the middle of the century. His use of prose constituted an innovation that was followed by Timoneda, Sepúlveda and Alonso de la Vega and which, fortunately, was abandoned by later dramatists. For the division into five acts used by some of his predecessors, he substituted a varying number of scenes. His conception of humor was far more primitive than that of Torres Naharro. His aim was to provoke loud laughter, and to gain this end, he employed the most obvious means, the stupidity and impertinence of a bobo, the cowardice of a braggart and the unintelligible jargon of a negress, a Moor or a Biscayan. We do not know to what an extent he may be regarded as the creator of these comic types, but there is no doubt that he made them popular. He is important in having enlarged the scope of the comedy of intrigue, but his chief contribution to the development of the Spanish drama lies in the creation or perfecting of a new genre, the paso, which will be discussed later.

The plays of Lope de Rueda were written at a time when the influence of Italian literature was predominant in almost every field of literary activity. The lyric poets, such as Cetina, Acuña and Hurtado de Mendoza, were following the example of Boscán and Garcilaso de la Vega, and imitating the Italian poets in form and content. Even the old ballads could not compete successfully with the translations and imitations of Boiardo and Ariosto, and Italian novels were appearing in Spanish dress. The temporary vogue of Italian comedy in Spain was as inevitable as in France and England, where Pierre de Larivey and George Gascoigne likewise laid tribute upon Italian models.

One of the best comedies of intrigue composed in Spain before the time of Lope de Vega is a comedia without title by a 
certain Sepúlveda, preserved in a manuscript dated at Seville, 1547. It consists of four acts in prose and is introduced by a prologue in which two friends are represented as discussing the play and its author before witnessing the performance. As in Gl'Ingannati, the plot turns on the disguise of page adopted by a young girl in order to be near her indifferent lover, and the discovery by her father of another young woman who had been lost in childhood. Besides, there is a resourceful lackey who is willing to appear to encourage the ridiculous pretensions of an old man in return for generous payment, and who succeeds in compassing the complete discomfiture of a necromancer, his accomplice. The prologue contains a defense of the art of playwriting, and an interesting appreciation of the excellence of Italian comedy. The author speaks with some experience, for his own play is a free translation of $I l V i l u p p o$ by the well-known Italian dramatist and novelist Girolamo Parabosco, first published at Venice in 1547.

The reduction of the five acts of Il Viluppo to four, involved changes in arrangement, particularly in the third act, but in general the order of scenes is retained, and most of them are close adaptations of the Italian text. Unlike Lope de Rueda in his versions of Italian comedies, Sepúlveda introduced no new comic scenes. It is true, however, that he dealt with his original in a critical spirit, and displayed a real dramatic sense. He showed good judgment in omitting certain unnecessary monologues and in suppressing the scenes in which the bawd Colombina appears. $\mathrm{He}$ also rearranged the scenes of the last act, making a more effective dénouement than in Parabosco's play. The prologue contains some original material, including the earliest Spanish reference with which I am acquainted to the dramatic unity of time, and one of the first recorded uses of the term entremés as synonymous with paso.

It is unfortunate that we have not sufficient evidence to identify the author. His acquaintance with Latin writers and 
classical mythology is proven by many references, and in one amusing scene he criticises the superficiality of Greek studies at that time, which implies some knowledge of that language. His own prose is characterized by dignity and grace, and gives evidence of a thorough knowledge and mastery of colloquial speech at its best. The dialogue is natural and in good taste, and his comic scenes never degenerate into the nonsense that mars so many plays of his time. With respect to style and construction, this comedia is vastly superior to any of the plays of Timoneda or Alonso de la Vega, and is not surpassed, in my opinion, by any play of Lope de Rueda.

Juan de Timoneda has many points of contact with Spanish literary history about the middle of the sixteenth century. Combining a keen business instinct with love for letters, he carried on successfully a bookselling and publishing business at Valencia and printed a number of books of real literary value. As we know, he was the editor and publisher of the four comedies of Lope de Rueda, which appeared in 1567 , and to him is also due the publication of the three plays of Alonso de la Vega.' Furthermore, he wrote plays himself; he collected and issued short stories gathered from many sources and was a pioneer in the collecting of popular poetry and old ballads.

In 1559 he printed a volume that included the Comedia de Amphitrion, Comedia de los Menemnos and Comedia de Cornelia (or Carmelia), and states in a preface that he has attempted to combine the use of prose after the fashion of the Celestina with the actable quality of the plays of Torres Naharro.

The Comedia de Amphitrion contains a prologue which presents in dramatic form a caso de amor. An old shepherd, named Bromio, urges his daughter, Pascuala, to declare her preference for one of her suitors, Morato or Roseno, both of whom have served her faithfully. The maiden replies that she will indicate her choice by a sign, and gives to one her garland and accepts a garland from the other. After her departure, the 
lovers dispute as to the meaning of her enigmatical reply and the audience is asked to decide which suitor had been favored. This casuistical discussion is derived from the first question in the fourth part of Boccaccio's Filocolo. It will be recalled that while searching for Biancofiore, Filocolo is obliged by reason of a storm to stop at Naples, where he is cordially received by Fiammetta and her merry companions. One afternoon, Fiammetta suggests that they amuse themselves by proposing questioni d'amore to a king who shall be elected by her comrades. She herself, however, is chosen as queen, and thirteen subtle questions are offered of the same type that the troubadours discussed in their tenzoni. The first is practically identical with the subject treated in Timoneda's prologue. The dramatic presentation of these questioni d'amore was not uncommon in aristocratic circles in Italy, and we know that this same problem was the basis of a brief play presented before Isabella del Balzo, Queen of Naples, some time prior to 1497. Timoneda may have known the Filocolo in its original text, or he may have been acquainted with the 'Thirteen Questions' as translated into Spanish by Diego López de Ayala and Diego de Salazar, and published at Seville in 1546 with the title Laberinto de Amor and again at Toledo in the same year with the title Trece questiones muy graciosas sacadas del Philoculo del famoso Juan Bocacio.

The title of the Comedia de Amphitrion bears the rubric, "traduzida por Juan Timoneda, y puesta en estilo que se puede representar". The second statement is correct, but the first must be interpreted in broad terms. Timoneda did not translate the Amphitruo, but made an acting version of the translation by Francisco López de Villalobos (1515)d This is proved by many cases of verbal similarity, and by the use as his last scene of a spurious addition which is also found in the version of Villalobos.

Timoneda was not a humanist, and was not moved by

'Benedetto Croce, I Teatri di Napoli dal Rinascimento alla fine del secolo decimottavo, Bari, 1916, p. I3. 
scholarly zeal to introduce Plautus to a Valencian audience. This witty comedy of adultery, with its equivocal situations, provided him with an interesting plot which he adapted to suit his needs. The servant Sosia, here baptized Sosia Tardio, has many characteristics of the conventional bobo and is more completely Spanish than the other personages. He knows the proverbs of Spain, revels like a true Valencian in olives and rice and makes many allusions to local customs. By his fidelity to his master, and his materialistic philosophy, he is a worthy forerunner of the immortal Sancho Panza.

Timoneda's Amphitrion, together with the Comedia de los Menemnos, were the first appearances of Plautus on the Spanish stage, as the translation of López de Villalobos was the first appearance of Plautus in Castilian. A second translation of the Amphitruo was made by Maestro Hernán Pérez de Oliva, published about $5_{525}$ with the title Muestra de la lengua castellana en el nascimiento de. Hercules, o Comedia de Amphitrion, and another version by an anonymous Toledan appeared in 1554. Anonymous translations of the Miles Gloriosus and Menaechmi, printed at Antwerp in I555, and' Pedro Simón Abril's version of the six comedies of Terence, published in 1577 , complete the list of printed Spanish translations of Latin comedy in the sixteenth century.

The Comedia de los Menemnos is preceded by a prologue in which three shepherds, enamoured of the shepherdess Temisa, present themselves before Cupid and ask him to decide which of them the maiden should prefer. Claudino has boasted of his physical strength, Climaco has assured her of his sincerity and generosity, while Ginebro has urged his suit on the plea of his prudence and wisdom. Cupid approves her choice of Ginebro, declaring that neither the strength of Hercules nor the generosity of Alexander will satisfy a discreet woman, who demands the fruits of real knowledge. The rejected suitors are satisfied with the decision, and recite the argument of the play. The source of this prologue is the third questione d'amore of the Filocolo. 
In the Comedia de los Menemnos, he shows more independence in dealing with his original. While the principal features of the plot of the Mencechmi have been retained, a number of unimportant scenes have been omitted or abridged, two new scenes have been added, and the play has been given a Spanish atmosphere. The doctor of the Menachmi is transformed through the influence of Ariosto into the necromancer Averroyz, and the scenes in which he takes part are among the best in the play. Averroyz is accompanied by a boy named Lazarillo whose relationship to the famous rogue is vouched for by the doctor himself. The play shows considerable dramatic skill, the various situations are logically constructed and the action moves along rapidly. It is hardly reasonable to suppose that Timoneda knew sufficient Latin to actually translate the Mencechmi. In composing Los Menemnos, it is likely that he made use of the Castilian translation printed at Antwerp in I555, or one of the Italian versions.

The Comedia de Carmelia (or Cornelia) is introduced by a caso de amor that is analogous to the prologues of the other two plays. The play itself is an ingenious comedy of intrigue. Lupercio is negotiating for the marriage of his son Fulvio to Carmelia, reputed to be the daughter of Polianteo, but the young people have good reasons to oppose the match. Carmelia had secretly married Taucio, son of Polianteo, three years before, and in spite of his long absence, she still hopes for his return, while Fulvio has a mistress in Mencía de Logroño, wife of the simple Cornalla. The unexpected appearance of the necromancer Pasquin brings about a solution of these difficulties. Lupercio engages him to cure Fulvio of a malady that threatens to prevent his marriage; Fulvio bribes him to keep the secret that his illness is feigned, and Taucio enlists his aid to recover his missing Carmelia. The charla$\tan$ succeeds, by rare good fortune, in satisfying everyone. $\mathrm{He}$ reunites Taucio and Carmelia, and proves that the latter is the long-lost daughter of Leonardo. Besides the figures of the necromancer and his attendant, the Comedia de Carmelia 
has other points of resemblance with Ariosto's Il Negromante. In both plays, the expedient of a feigned malady is adopted to prevent a marriage, and in each case the father of the young man applies to a necromancer to cure his sickness. From a reference to the capture of Bugia by the Moors, its date of composition must be placed after I 555 .

In his book on the drama at Valencia, M. Henri Mérimée questions the good faith of Tinoneda with respect to some of the plays ascribed to him. He calls attention to the fact that while the title of this play is Comedia de Cornelia, the heroine's name, except in three cases, appears as Carmelia. Furthermore, while Valencia is supposed to be the setting, the local colour is almost exclusively Castilian. M. Mérimée suggests that a play with Castilian setting, probably based upon Italian materials, fell into Timoneda's hands and was revised by him and published as his own work. This original was considerably abridged, and the early incidents were included in the prologue so that the later portions might be understood. For my part, I doubt whether we have sufficient evidence to deny to $\mathrm{Ti}$ moneda the authorship of this play. The confusion of names is not very important, and so far as the local colour is concerned, it may be argued that Timoneda composed the play for some traveling company and adapted his local allusions to a Castilian audience. It was a common practice in both Latin and Italian comedy to include some of the preliminaries in the prologue in order to secure unity of action, and to a certain degree, unity of time. The Comedia de Carmelia seems to me to give evidence of the same skill in construction and dialogue that we find in some of the original scenes of the Comedia de Amphitrion and Comedia de los Menemnos.

In ${ }_{5} 65$ a volume entitled Turiana, containing six plays

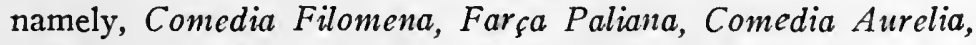
Far ça Trapacera, Farça Rosalina and Far ça Floriana, and a number of entremeses, was published at Valencia by Joan Diamonte, an obvious anagram of Timoneda. The publication of the volume was delayed for some reason since the first 
three plays bear the date 1564 . All of these plays are in verse and, with the possible exception of the Far far inferior to any dramatic work published by Timoneda under his own name. We have no right, and it would in this case be unjust, to ascribe to him authorship which he himself did not claim.

The prologue to the Comedia Filomena promises us an unfamiliar theme, which turns out to be the well-known story of the violation of Philomela, narrated by Ovid, and dramatized in Italy by Parabosco, Gregorio Corraro and Lodovico Domenichi, and in Spain by Guillén de Castro and Rojas Zorrilla. The impertinence of the inevitable bobo fails to relieve the gruesome details of the play which is, from every point of view, ridiculous.

The impression created on the reader of the Far ${ }_{\xi} a$ Paliana is akin to the nightmare of the first scene, the consequences of which are developed in the play. The action covers some twenty years, beginning with the exposure of a newly-born baby by its parents, and ending with its ultimate recovery under preposterous circumstances. The play has not a single redeeming quality.

The influence of Torres Naharro is discernible in the division into five acts of the Comedia Aurelia, which on internal evidence may be ascribed to the early part of $1560 .^{1}$ The exposition is given in the first act, the denowement in the fifth, and the interval is filled up with wholly irrelevant matter. The plot, which deals with the recovery of the missing half of a ring, thus enabling a brother and sister to gain possession of their patrimony, is highly fantastic, and scarcely deserves notice. A paso in which a Portuguese, Spaniard, Biscayan and Frenchman discuss in an almost unintelligible jargon questions of national honour, resembles a similar incident in the Comedia Tinellaria, and there are also minor similarities with the Comedia Aquilana and Comedia Calamita.

\footnotetext{
${ }^{1}$ Mérimée, op. cit., p. 158.
} 
By far the best of the plays included in Turiana is the Farfa Trapacera, which unfortunately is extant only in an incomplete form. This is a close adaptation of Ariosto's La Lena, and owes most of its interest to its diverting original.

The Farfa Rosalina is essentially undramatic. In the first scene, two friends who have suffered much from the hand of Fate, determine to renounce the world, and toward the end of the play, reach a monastery, after resisting successfully the assaults of World. The five pages that have been preserved of the Farfa Floriana, the last play included in the Turiana, are not sufficient for us to form any judgment concerning its nature or value.

Timoneda's interest in the stage was likewise responsible for the preservation of three plays by Alonso de la Vega, namely, the Comedia Tholomea, Tragedia Seraphina and Comedia de la duquesa de la Rosa, published by him in 1566 . We know little of this dramatist, save that he was an actor and died at Valencia between 1560 and 1566 . The Comedia Tholomea is based upon the unexplained resemblance between two youths, both named Tholomeo, and the confusion in identity resulting from the substitution of one for the other by their nurse. The denouement is far less convincing than in the first patraña of Timoneda's Patrañuelo (1566) which deals with the same story, and which specifically states that it had appeared in dramatic form. It is reasonable to suppose that both writers worked from a common source, and that the extravagant ending of the Comedia Tholomea, with its accompaniment of mythological characters, is wholly due to Alonso de la Vega. The comic scenes clearly show the influence of Lope de Rueda.

The Tragedia Seraphina is a completely unsuccessful attempt to give a pastoral and mythological setting to a comedy of intrigue. As Menéndez y Pelayo remarked, the poetical idea of a maiden enamoured of Cupid and the death of the lovers in a lonely forest, contains the elements of a lyrical drama of real beauty, but the play is marred by frequent lapses from good taste, and by the irritating interruptions and comments of the comic characters. 
Far superior is the Comedia de la duquesa de la Rosa, which is introduced by a caso de amor with pastoral setting analogous to the prologues of Timoneda's three comedies. This play, as well as the seventh patraña of Timoneda, is based upon Bandello's story entitled Amore di Don Giovanni di Mendozza e della Duchessa di Savoja, or upon some text derived from it. However, Alonso de la Vega attributes to the duchess a dignity and nobility of character which she does not possess in the other versions. Her passion, as Menéndez y Pelayo says in his excellent appreciation, is the chaste recollection of an innocent love of childhood, and her pilgrimage is an act of piety. When she meets Dulcelirio at Burgos, no sign of recognition is given, save that he offers her a cup containing the ring she had given him years before when he was taking leave of her father's court. Alonso de la Vega rarely rises above mediocrity, but in a few scenes of this play, he shows a capacity for poetic feeling and delicate fancy.

Except that it is composed in coplas de pie quebrado, the influence of Lope de Rueda is apparent in the anonymous Farsa Rosiela, preserved in an edition of 1557 . The play rests upon a case of mistaken identity, and its theme is that gentility must reveal itself whatever be one's accidental station in life. It bears a certain resemblance to the many plays of the following century which have a principe villano as the central figure. ${ }^{3}$

The well-known story of Griselda was dramatized by Pedro Navarro in his Comedia muy exemplar de la marquesa de Saluzia, llamada Griselda. An actor, manager and playwright named Navarro, contemporaneous with Lope de Rueda, was praised enthusiastically by Cervantes, Rojas Villandrando and Lope de Vega, and while there is nothing in this play to justify such eulogies, his identification with the author of this play is probably correct. Its immediate source is not the Decameron, but Foresti's Supplementum chronicorum orbis ab initio mundi, which was translated into Spanish by Viñoles in 1510 , and also

${ }^{1}$ See J. Gómez Ocerin's edition of Vélez de Guevara's El rey en su imaginación, Madrid, I920, pp. I09-13. 
Timoneda's Patrañuelo. The play defies unity of time, for it opens with Galtero's offer of marriage to Griselda, and ends with the restitution of her child twelve years later. It requires Griselda-like patience to read the five acts of this bungling adaptation of Boccaccio's story.

In Spanish, as in other countries of Europe, the performance of Latin plays was regarded as an important feature of the instruction in Latin and rhetoric. These performances were encouraged by the University authorities because it was realized that they served the pedagogical purpose of familiarizing students with colloquial Latin. We know, for example, that betwen $153 \mathrm{I}$ and 1539 , five performances of Latin plays were given by students of the recently organized Studi General of Valencia, including a presentation of a play of Plautus in 1532. Occasionally, the old Roman comedies were replaced by Latin translations of well-known contemporaneous plays or by original compositions that represented a compromise between classical practice and modern taste. The Statutes of the University of Salamanca, in 1538 , mention performances before the students of comedies of Plautus and Terence, or tragicomedies.

The history of the School Drama in Spain is only imperfectly known, and its study is rendered particularly difficult because of the rarity of the texts. The earliest of these plays of which we have any record is the Hispaniola by the Erasmist, Juan Maldonado, composed in Latin prose and in five acts. ${ }^{1}$ It is said to have been written in 1519 , and was performed in Portugal, and with great applause at Burgos. The earliest extant edition was printed at Burgos in 1535 , and there was an earlier edition of Valladolid. Plautus was the author's model, and the play deals with the rivalry of two young men for a young woman's love.

Of greater significance is the dramatic activity of Juan

${ }^{1}$ I know this only from the note by A. Bonilla y San Martin in his translation of Fitzmaurice-Kelly's Historia de la literatura española, Madrid, 1901, p. 230 . 
Pérez who occupied the Chair of Rhetoric at the University of Alcalá from about 1537 until his death in 1545 at the age of thirty-three years. We are told that he often entertained the University with his comedies, four of which, the Necromanticus, Lena, Suppositi and Decepti, were published at Toledo by his brother in I 574. The first three were translated from Ariosto, and the last from the anonymous Gl'Ingannati. It is likely that Pérez was also the author of a brief Latin comedy performed at Alcalá before Prince Philip in 1539 or 1540 with the title Ate relegata et Minerva restituta. Here the author attempts to reconcile the privileges of the University with the rights of the archbishop, and to win for the University the sympathy of Archbishop Juan Tavera who already showed a disposition to insist upon what he believed to be his prerogative. Minerva relates to Mercury her peregrinations in various lands, meeting everywhere with deceptions and disappointments, until she established herself in the great University founded by Cisneros. But still she is not at peace, for Ate and Momus, with their slanderous tongues, are trying to create discord between the Archbishop and the University. If they succeed, Minerva will be banished from Alcalá. This little play did not, apparently, aid in the settlement of the dispute here presented over the control of the University's affairs, but it gives a good idea of the special purpose that might be served by a School play.

The most prominent figure in the Spanish School drama was the Aragonese Lorenzo Palmyreno, who, as professor at the Studi General of Valencia, attempted by means of the drama to make classical studies popular, and who restored to Valencia its academic stage. Selections from three of his plays, namely, the Comodia Lobenia, (I546), Comodia Sigonia and Comodia Octavia, were published in 1566 . These are too fragmentary to allow us to form a definite opinion as to their value, but it is evident that by the use of prose, occasional dialogues in Castilian and conventional incidents of the comedy of intrigue, he attempted to give a classical setting 
to modern material. There is still less of Plautus and Terence, and a predominance of Castilian over Latin, in his Fabella Enaria, performed at the University in 1574 . The action is laid during the reign of Vespasian, but the vicissitudes of the Prince Alberto, who falls in love with the daughter of a king of Denmark, effects his escape from prison with her aid and wins her hand by his valor in single combat, are thoroughly romantic. We cannot question the author's explanation that he had imitated Spanish farces, and not the serious art of Terence, in order to please his audience.

We have already noted that in the Nativity scene of Iñigo López de Mendoza's Vita Christi, and in the Christmas plays of Juan del Encina, Gil Vicente, Lucas Fernández and their successors, shepherds appear whose quarrels and games enliven the presentation of incidents of sacred story, and whose ignorance served as a pretext for the explanation of theological doctrines. Singing and dancing were prominent features of these compositions, but only in Encina's second Egloga en requesta de amores are a song and dance employed to separate two scenes. In a similar manner, the Egloga de Placida $y$ $V$ itoriano is divided into two parts or acts by a song, and two shepherd's scenes are introduced for the sake of comic relief.

In the course of time, the incidental comic scenes were developed with more or less detail and completeness until they possessed unity of action, without reference to the play of which they formed a part. Such, for example, is the trick played upon Gomecio by Lenicio at the opening of the fourth act of the Comedia Serafina of Torres Naharro. An incident of the first act of the Comedia Calamita, in which Jusquino convinces Torcazo of his supposed relationship to him, and the description of the trick by which Fileo relieves Torcazo of certain provisions, have dramatic unity, and in content and spirit resemble the pasos of Lope de Rueda. A similar use of comic scenes, without organic connection with the princpal action, is also found in the Comedia Radiana and Comedia Tesorina. The characters of these comic scenes, which later 
were to form an independent genre, are invariably taken from the lower classes of society.

Several plays of Sánchez de Badajoz contain excellent examples of a brief action completely developed and with little relationship to the chief plot. The Farsa del rey David presents an amusing contest between a shepherd and a Portuguese, and the Farsa de Moysen a somewhat similar scene between a shepherd and a negro. In the Farsa Teologal, a shepherd frightens a braggart soldier almost to death with a jack o' lantern. The soldier explains that severe toothache had caused him to faint, and an obliging French dentist extracts two teeth before his hapless victim confesses the truth. This episode has dramatic unity, and the same is true of the last scenes of the Farsa de Salomon, which can bear comparison with the best pasos of Lope de Rueda. The Farsa Militar. contains an independent farcical scene that recalls Timoneda's Passo de dos ciegos y un mogo.

At least three of the later plays of Gil Vicente show the development of a comic incident into a separate entity. The diverting episode of Ninguem and Todo a Mundo has no definite relationship with the Auto da Lusitania (I532), and the religious element in Os mysterios da Virgem (I534) is so completely overshadowed by the delightful interlude of Mofina Mendes that the latter gives to the play a new title. The Floresta de enganos ( 1536 ) is introduced by a witty scene in Castilian, which is followed by a brief picaresque incident in Portuguese, and both of these are mutually independent and unrelated to the rest of the play.

It is evident from the above examples that by the third decade of the sixteenth century, a farcical scene with dramatic unity and with characters drawn from the lower classes, was occasionally employed for the sake of comic relief, or to serve as an introduction, in which case it replaced the earlier dramatic monologue. We do not know how long before the middle of the sixteenth century the term paso was applied to these independent scenes, nor at what period they were first 
regarded as a separate dramatic type. The same uncertainty exists with respect to the term entremés, which seems to have been first used in Catalan and Valencian territory, and which after being employed with the meaning of entertainment in its broadest sense, ${ }^{1}$ and show or pageant, finally became synonymous with paso. The earliest recorded use of the name entremés with the meaning that was to prevail later, occurs in the prologue to the comedia of Sepúlveda of the year 1547 . The word is also used to designate an amusing scene in Sebastián de Horozco's Representacion de la historia evangelica del capitulo nono de Sanct Joan, in which a lawyer completely fleeces a client before undertaking his case, and which belongs to approximately the same period. Sebastián de Horozco is also the author of an entremés without title, performed at Toledo on St. John the Evangelist's day. This vivid picture of picaresque types, with its pronounced clerical satire, must have produced a strange impression upon the audience of nuns for which the author states that it was written.

While it is true that Lope de Rueda was not the creator of the paso, it cannot be doubted that he perfected this new literary type. An appendix to Timoneda's edition of Rueda's comedies and colloquies, published at Valencia in 1567 , contains a list of the pasos contained in these plays which might be transferred to other compositions. This clearly indicates that these farcical scenes were regarded as independent entities, which might be used in any play without reference to

${ }^{1}$ It appears that originally the term entremés was applied to food served at a banquet in some ingenious form. For example, after a banquet given to celebrate the coronation of dona Sibila by Pedro IV in $138 \mathrm{I}$, a fine entremés was served, which consisted of a peacock, elaborately prepared and bearing verses expressing loyalty to the Queen. The name of entremés given to this gastronomic triumph in the Catalan text indicates its relationship to the French entremets and Latin intermissum. Some critics have accepted the statement of Agustin de Rojas in his Loa de la comedia that the entremeses received their name "porque iban entre medias de la farsa", but this explanation rests only upon popular etymology. 
the original context. The Comedia Armelina contains one episode of this sort, in which the moza Mencieta attempts to cure the simple Guadalupe of chronic drowsiness, and the Comedia de los engañados has another, in which the stupidity of the simple Pajares furnishes the comic element. The amusing paso of the rufián cobarde Vallejo in the second scena of the Comedia Eufemia and the paso of the lackey Polo and the negress Eulalla in the seventh scene of the same play, serve to fill in the time required for a change of scene. The Comedia Medora opens with a highly diverting paso of the discomfiture of the rufian cobarde Gargullo, and the second and fourth scenas of the same play present bits of roguery, which are so frequently described in these detachable scenes. The Coloquia de Camila includes two pasos, and whatever interest the $\mathrm{Co}-$ loquio de Tymbria may possess is due to its five pasos. In the course of time, the use of certain characters in these brief episodes became conventional, and in the prologue to his Ocho comedias, Cervantes speaks of the skill of Lope de Rueda in acting entremeses "de negra, de rufián, de bobo y de vizcaino".

A collection of seven pasos of Lope de Rueda "para poner en principios y entremedias de colloquios y comedias" was published at Valencia by Timoneda in 1567 with the title $E l$ deleitoso. Two of these, the fifth and seventh, were adapted to serve as opening scenes, and the others were suitable for use as interludes. The first deals with the inability of the lackey Luquitas and the simple Alameda to explain to Salcedo's satisfaction their long absence from the house, and ends with the conventional paliza. Two of the same characters appear in the second paso, which allows us to assume that these scenes originally formed part of the same play. Here Salcedo plays upon the credulity of Alameda, who proves in a moment of inspiration that he is not so great a fool as his master believed.' The third, often called Cormudo y contento, describes the sacrifice made by the simple Martin to cure his wife of her illness, while she diverts herself with a young student. The fourth 
paso, called by Moratín El convidado, describes the embarrassment of an impecunious student who, after inviting a fellow-townsman to dinner, is obliged for financial reasons to feign illness in order to cancel the engagement gracefully, and is betrayed by another student in whom he had confided. The scene was probably based upon an actual occurrence, and is related as such in both El crotalon and El escolastico of Cristóbal de Villalón. The fifth shows how easily the simple Mendrugo is robbed of his provisions while he listens to a glowing account of the delights of the Land of Cockayne. An ingenious theft is also the subject of the sixth. The seventh, commonly called Las aceitunas, describes a quarrel between man and wife over the price they will ask for olives that are not yet planted. This is the best one-act play written in Spain in the sixteenth century, and has pleased audiences in our own day.

The six pasos "asi de lacayos como de simples y otras diversas figuras" of Lope de Rueda "y otros diversos autores", published by Timoneda in 1570 in a volume entitled Registro de representantes, have less literary and dramatic merit than those just mentioned, but show that the form has become fixed, with characters and situations which in the course of time became conventional. The first presents a scene frequently found in later entremeses, in which a pair of rogues attempt to prescribe for their master's patients during his absence, with lamentable consequences. The second describes the success of two students in a school for thieves, in relieving a simple of his provisions by a clever trick. In the third, the simple Rodrigo de Toro uses the argument of a club to escape from a trap that has been set for him. In the fourth, a cut-purse is unable to evade the officers of the law, in spite of his glib tongue. The fifth is a paso de rufian cobarde, which closely resembles the second scene of the Comedia Eufemia. The theme of the sixth is the unsuccessful attempt of the simple Pancorbo to shift upon another the responsibility for having eaten a pound of sweets. 
In these compositions, no attempt is made to create a background, nor to study character. The length of the action is the same as the time required to present it, and no more. There is no exposition of a plot, for the action is too rapid, and besides, the situation is rarely complex. A couple of hungry fellows may meet a peasant carrying provisions. The audience knows at once, without explanation, that there will be a contest of wits, with the food as the prize. The basis of these plays is usually a time-worn deception or practical joke, which was susceptible of countless new settings and variations.

There is much similarity between some of the characters of the pasos and of the Italian commedia dell'arte, and structurally the paso or entremés served the same function as the lazzo or intermedio of the Italian plays, but there is no definite evidence, at least in the sixteenth century, of any influence of the commedia dell'arte on the development of the entremés.

The Entremés del mundo y no nadie, attributed to Lope de Rueda in the manuscript in which it is preserved, apparently was written to introduce a religious play. Here the thesis that to him that hath shall be given, is illustrated by a brief scene between Mundo and No Nadie, which even in its crude form resembles versions of the Somebody and Nobody conceit found in other literatures. It shows none of the characteristics of Lope de Rueda's pasos, and its verse form is also an argument against his authorship. The fact that his name occurs as one of the characters merely proves his popularity on the stage.

The title-page of the Comedia de Amphitrion states that the play contains "graciosos passos", but Timoneda evidently employed the term in the sense of incident, as it was also used by López de Villalobos in the prologue to his translation of Amphitruo, since neither Amphitrion nor the other two plays of Timoneda include irrelevant comic episodes with dramatic unity. Several such scenes, however, are found in the volume of anonymous plays published by Timoneda in the volume entitled Turiana ( $\left.1564-{ }_{5} 5_{5}\right)$, especially in the Farfa Paliana and Comedia Aurelia. 
The same volume contains five "passos y entremeses" in verse, which Timoneda declares were intended as introductory scenes. The Entremes de un ciego y un mofo y un pobre presents a blind man who is asking for alms, and who blames his non-success upon Hernandillo, his guide. The latter shows no concern over the threats of a thrashing, and makes sport of his master when he tries to pitch his voice in a particularly pathetic key. A competitor appears in the person of another beggar; they begin to abuse one another and finally come to blows. The influence of Lazarillo de Tormes is still more marked in the Paso de dos ciegos y un moso, which served as a prologue to some Christmas play. Palillos enters, saying that he hopes to find a master in the audience, and narrating humourously his qualifications. He is not a thief, he declares, but he was obliged to steal six ducats from his last master, a blind man who nearly starved him. As he describes his theft, two blind men approach asking for alms, and in one of them, Martín Alvarez, Palillos discovers his late master. The two beggars recognize one another and begin to talk of professional matters. Pero Gomez notes that his companion has no guide, and Martín narrates his experience with Palillos, the greatest rascal he ever saw. Palillos overhears the compliment, and decides to have some fun at their expense. Pero confides to his friend that it is safer to carry money on one's person than to leave it at home for thieves to steal, and whispers that he has five or six ducats hidden in his hat. At that moment, Palillos snatches Pero's hat and runs away, while Pero hotly accuses his companion of the theft, which Martín indignantly denies. The same trick, with a few changes, was described by Timoneda in his twelfth patraña, but the dramatic version is far superior. ${ }^{1}$ In the arrangement of the incidents and in the individuality given to Palillos, this can stand comparison with any of Lazarillo's experiences.

The Passo de dos clerigos, cura y benficiado, y dos moģos

1 This trick has much in common with the first part of the wellknown French fabliau, Les trois aveugles de Compiègne. 
suyos simples treats, after the fashion of Sánchez de Badajoz, a quarrel between two unworthy members of the clergy concerning their respective duties. In the Passo de un soldado, un moro y un hermitaño, a Moor is the victim of a clever trick played upon him by a soldier. The Passo de la Razon y la Fama y el Tiempo is a unique example of a paso dealing with allegorical and serious material.

In addition to those already mentioned, a few anonymous entremeses have been published from sixteenth-century manuscripts. The most important of these is the Entremes de las esteras, contained in a codex of ninety-six plays, of which this is the only secular one, preserved at the National Library of Madrid. This describes effectively the possible embarrassments that attend love-making in the kitchen. The Entremes del astrologo borracho, probably of the year 1583 , is a rare example of the use of drunkenness on the Spanish stage for comic effect. Two entremeses without title treat the familiar theme of the deceits practised by a wife upon a stupid husband, and the Entremes de un viejo que es casado con una mujer moza, which has a similar basis, is derived from the ninth novella of the Seventh Day of the Decameron. ${ }^{1} \mathrm{~A}^{\prime}$ rufián cobarde plays the leading rôle in the Entremes de un muchacho llamado Golondrino, and the pretentious airs of a young student are satirized in the Entremes de un hijo que nego a su padre. The cunning exploits of thieves are described in the Segundo entremes de los ladrones and in the Segundo entremes de. Pero Hernandez. All of these were written in prose.

These short comic scenes were important features of religious as well as secular entertainments, and in making contracts for Corpus plays, the municipalities usually took care to stipulate the number of entremeses to be performed with each auto. In a number of cases, the words "Aqui ha de

${ }^{1}$ G. T. Northup, $o p$. cit., p. xiii, notes that the same situation is found in a scenario printed by Bartoli, entitled Gli Intrighi d'Amore ovvero la finestra incantata. 
haber un entremés' in the manuscript clearly indicate the independent nature of these compositions. We have comparatively few texts of entremeses in the latter part of the century, but there is no doubt that they continued to be performed, and that they enjoyed the public's favour. Furthermore, the entremés in the early part of the seventeenth century has more points of contact with the work of the preceding century than has any other dramatic form. To the reader of to-day, the early entremeses are a source of unfailing pleasure because of the light they cast upon popular manners, customs, superstitions and language of the sixteenth century. 


\section{CHAPTER VII}

\section{Religious Drama in the Latter Half of the Sixteenth}

Century

The traditions of the Christmas plays of Encina and Fernández, with the addition of a pronounced tendency toward allegory which we have already found in the works of Diego Sánchez de Badajoz, were continued in a few compositions of the latter half of the sixteenth century. A play of this type consisting of three autos or scenes, is included in an edition of the works of the Portuguese poet, Jorge de Montemayor, which was published at Antwerp in the year 1554 . It was performed at Christmas matins before Prince Philip, between the years 1548 and 1553 . The first scene presents in allegorical fashion the disobedience of Adam and Eve who fall victims to the wiles of Sensuality, and the promise made by Hope of the birth of the Redeemer who will restore to humanity its lost estate. This prophecy is fulfilled in the second scene, and after an explanation of the doctrine of Redemption, Time goes off to Limbo to inform Adam of Christ's birth. The third scene contains more popular elements, and ends with the visit of three shepherds to the manger. Comic elements are introduced without success in an attempt to enliven these theological discussions. The play is totally lacking in inspiration or interest, and it is hard to believe that the author of the Diana could have written a work so devoid of merit.

Still more primitive is the Danza del santisimo nacimiento de nuestro señor Jesucristo by Pedro Suárez de Robles, printed at Madrid in $156 \mathrm{r}$. The stage directions inform us that the play was introduced by a procession in which shepherds, r 38 
angels, Joseph and the Virgin with the Christ Child marched to the high altar, where the Child was placed in a manger. Dancing. and singing were prominent features of this composition, which shows little advance over the earliest plays of Encina. An angel mounts the pulpit and announces the birth of Jesus. After the shepherds recover from their surprise, they draw near to the manger where they are welcomed by Joseph. Each of the shepherds offers a gift to the Christ Child, the Virgin promises them her protection, and the play ends with the song of shepherds and angels, in alternate couplets.

The only extant edition of El pecador by Bartolomé Aparicio bears no date, but judging from its general character, the play seems to belong to the middle of the sixteenth century. The didactic purpose to teach theology is apparent in the dispute between Justice and Mercy regarding the punishment of Sinner for his transgression, and the explanation of the doctrine of Redemption. Mercy announces the incarnation of God in a Virgin, and the play ends with the Nativity scene.

To approximately the same period belongs a Comedia a la pastoril para la noche de Navidad, preserved in manuscript form at the National Library of Madrid. Composed in quintillas, the play is introduced by a prologue recited by a faraute and is divided into three estancias or stations, which apparently refer to the place of representation. The third estancia is divided into two nocturnos, a liturgical word that does not occur in any other Spanish play with which I am acquainted. The manuscript contains interesting information concerning the costumes worn by the various characters. Music played an important part in the performance, and a number of songs were introduced which were doubtless already familiar to many of the spectators.

The play shows an interesting combination of the dispute of the four Virtues, Mercy, Peace, Truth and Justice, with the Nativity scene. The allegory of the Four Daughters of God, or Procès de Dieu, based upon Psalm 84:I I, "Miseri- 
cordia et Veritas obviaverunt sibi; Justitia et Pax osculatae sunt ", enjoyed extraordinary popularity throughout the Middle Ages. The author followed closely the version of the allegory that is found in the sermon of Bernard de Clairvaux entitled In Festo Annuntiationis Beatae Mariae Virginis, upon which nearly all the dramatic forms of the story in other literatures are based. In the Spanish play, however, the dispute serves to introduce the Nativity rather than the Annunciation, which is found in most other versions.

The anonymous Farsa del sordo shows the same tendency toward the complete secularization of the Christmas story as Encina's Egloga de las grandes lluvias. It consists of a series of insignificant scenes, which serve to introduce the announcement by a shepherd of 'Christ's birth. The earliest dated edition contains a license to print of the year 1568 . The ascription of this play to Lope de Rueda, on the authority of an edition of 1616 , in which his name appears as author, must be regarded as exceedingly doubtful.

The Descent from the Cross is described in an anonymous Auto de la quinta angustia que nuestra Señora passo al pie de la cruz, published at Burgos in I552. After an introductory scene, in which Joseph of Arimathaea secures permission from Pilate to place in a sepulchre the body of the Crucified One, the play presents the grief of the friends of Jesus and the anguish of the Virgin as preparations are made for the burial. While lacking in dramatic power, its lyrical qualities imbue it with a truly devotional spirit.

The Auto llamado Lucero de nuestra salvacion, que trata del despedimiento que hizo nuestro Señor Jesucristo de su bendita madre by Ausías Izquierdo Zebrero, first published in I582, offers more human interest in its portrayal of the efforts of the Virgin to dissuade Jesus from going to Jerusalem to meet his. death. He entrusts her to the care of St. John, and she is then left alone with the symbols of the Passion.

In its combination of themes derived from the Old and New Testaments, the Victoria de Cristo of Bartolomé Palau 
appears at first sight as an example of the cyclic type of composition with which we are familiar in English and French literature, but in reality it must be regarded as an Easter play, with a rather detailed exposition of Old Testament history interpreted in the light of the Resurrection. Its division on a chronological basis into six parts, with a varying number of autos or scenes, is unique in the Spanish drama. The general subject of the play is the spiritual captivity of mankind as a consequence of the original sin, and extends from the disobedience of Adam and Eve to the Last Judgment, with the redemption of mankind through Christ. There is no reason to suppose that it was written any considerable time before 1570, the year of its earliest dated impression. Its popularity is attested by the publication of no less than nine editions, and it is still performed occasionably in Catalonia and Aragon.

By far the most important monument of the Spanish religious drama in the latter half of the sixteenth century is al codex of ninety-six plays preserved at the National Library of Madrid, and edited by Léo Rouanet. All but one of these, namely, the Entremes de las esteras, treat sacred themes, and all are anonymous, with the exception of the Auto de Cain $y$ $A b e l$, which bears the signature of Maestro Jaime Ferruz. In the opinion of their editor, three of these plays, namely, the Auto del robo de Digna, Auto de los desposorios de Moysen and Auto de Naval y Abigail, were written by Lope de Rueda. All but three are in verse, with the quintilla as the prevailing measure. The manuscript copy of the Auto de la Resurrection de Christo (LX) contains a license for performance at Madrid in 1578 , and a number of the compositions may probably be identified with plays performed at Seville. With the exception of two coloquios, derived from the pastoral Coloquio de Fenisa, and the Entremes de las esteras, these plays bear the name auto or farsa, the latter being used to designate allegorical compositions in honor of the Sacrament, while the former was apparently applicable to any type of religious play. 
The similarity in the structure and spirit of these plays indicates that their authors were following an established tradition. They begin with a loa or argumento, in prose or verse, which usually includes a greeting to the audience, a summary of the plot and a request for silence. They generally end with a villancico, and occasionally are divided into two parts by an entremés, which is sometimes merely indicated in a stage direction. It is the comic elements that are chiefly responsible for their air of similarity. In almost all of them a clown appears, designated indiscriminately as pastor, bobo, villano and simple, whose dull understanding provokes explanations concerning theological doctrines, and whose silly chatter, impertinence and fondness for food afford comic relief after serious scenes.

It is by no means easy to classify accurately the ninety-five religious plays of this codex, nor to determine on what festivals they were performed. The Aucto del rey Nabucdonosor cuando se hizo adorar (xiv) is inspired by the spirit of penitence which is characteristic of Advent, and the Auto del sueño de Nabucdonosor (XV), with Daniel's prophecy of the Incarnation as its central point, refers to the same season. La justicia divina contra el peccado de Adan (xliii) presents a version of the allegory of the Four Daughters of God, already found in the Comedia a lo pastoril, and frequently employed as an introduction to Christmas plays. In this case, only two sisters appear, Justice and Mercy, and the dispute takes place shortly after the disobedience of Adam. The theme, therefore, is not the immediate, but the ultimate redemption of man. The Aucto de los hierros de Adan (xliv) presents the release of Adam and his sons as a consequence of the Redemption. The Aucto de la culpa y la captividad (xlv) describes the imprisonment by Guilt and Captivity of various characters who secure their freedom through the announcement of the birth of Christ. This shows the influence of Palau's Victoria de Cristo, except that these incidents are here related to Christmas instead of Easter. A' shepherd who has 
heard the angel's song serves to connect the Aucto de la circuncision de nuestro Señor (li) with the Christmas festival, and another post-Christmas play is the Aucto de la huida de (sic) Egipto (lii), to which the prophecies of Christ's destiny, pronounced ingenuously by a band of gipsies, impart a real charm. While in subject matter these plays are related to the Advent and Christmas seasons, we cannot definitely state that they were performed on Christmas day, with the exception of the Aucto de la Culpa y la Captividad, which on internal evidence may be called a Christmas play.

Five plays, namely, the Aucto de la degollacion de Sant Juan Baptista (xxxv), Aucto del hijo prodigo (xlviii), Auto de la entrada de Cristo en Jerusalen (xlvi), Auto de la conversion de la Madalena (lxiv) and Auto del hospedamiento que hizo Sancta Maria a Christo (lvi) deal with incidents of the Ministry of Christ. The first presents with unusual dramatic power the execution of John the Baptist. The Aucto del hijo prodiga sketches only in briefest outlines the Prodigal's downfall, and is far inferior to Luis de Miranda's Comedia Prodiga. The Auto de la entrada de Cristo en Jerusalen treats with simple dignity the scene of Christ's entry into Jerusalem and the driving of the money-changers from the temple. The transformation of a sinful woman into a devoted disciple of Jesus is pleasingly described in the Auto de la conversion de la Madalena. Less interesting is the Auto del hospedamiento que hizo Sancta Marta a Christo, which deals with undramatic material.

Five plays, namely, the Auto del despedimiento de Christo de su madre (liv), Aucto del descendimiento de la cruz (xciii), Aucto de la resurrecion de nuestro Señor (xcv) and two plays entitled Auto de la resurrection de Christo (lx) and (lxi), deal with incidents related to Christ's Passion and Resurrection, and were presumably performed on Good Friday and Easter; and two plays, the Auto de la destruicion de Jerusalen ( $\mathrm{xxx})$ and Auto de la redencion del genero humana (xciv), are also related to the Easter festival.

The Auto del despedimiento de Christo de su madre recalls 
Ausias Izquierdo Zebrero's Lucero de muestra salvacion, but contains less symbolism, and emphasizes the element of physical horror in Christ's description to the Virgin of the sufferings he must endure on the Cross. The Aucto del descendimiento de la cruz closely resembles, even in minor details, the Auto de la quinta angustia, already discussed. The Aucto de la resurecion de nuestro Señor (xcv) is a regrettable attempt to popularize the Easter play by the introduction of trivial incidents. Descended from the Officium Peregrinorum, the play presents the appearance of Christ to the Virgin, Mary Magdalen and other disciples after the Resurrection. The author displays execrable taste in the description of Christ's interview with Mary Magdalen, and the final scene, in which certain of the apostles engage in a game with Lucifer, is scarcely less objectionable. The Auto de la resurrection de Christo (1x) performed at Madrid on Easter, 1578 , contains popular and allegorical figures, and centers about the account of the Harrowing of Hell, recited by Time. Even less dramatic is the Auto de la resurrection de Christo (1xi), which consists of a conversation between the four Evangelists and two allegorical figures concerning the doctrine of Redemption. The Aucto de la destruicion de Jerusalen treats in a spirited manner the legend of the destruction of Jerusalem by Vespasian in return for his miraculous cure from leprosy. The Aucto de la redencion del genero humano presents with allegorical figures the Harrowing of Hell, and with the exception of a few additions and changes, is identical with the sixth part of Palau's Victoria de: Cristo.

Three plays entitled Aucto de la Asuncion de nuestra Señora (xxxi, xxxii and lxii), to which may be added the Auto de la Assumption de nuestra Señora, not included in the codex under discussion, but published by Rouanet in the Appendix to that collection, the Colloquio de Fenisa en loor de nuestra Señora (lxv), and the Auto de acusacion contra el genero humano (lvii), were all written in honor of the Virgin. The Colloquio de Fenisa is an insipid version a lo divino of the 
pastoral composition with the same title, already mentioned, which seems to have enjoyed an undeserved popularity. The Auto de acusacion contra el genero humano presents a trial scene in which Satan lays claim to the possession of Mankind, the Virgin acts as his advocate, and Christ serves as judge. Its source is a version of the Processus Belial, attributed to Bartolus, which had extraordinary vogue throughout the Middle Ages. The theme recalls the Catalan Mascarón, and analogues in other European literatures. ${ }^{1}$

Eleven plays contained in this same manuscript deal with lives of Saints, namely, the Auto de Sant Jorge quando mato la serpiente (xxvi), Aucto de Sanct Christoval (xxvii), Aucto de un milagro de Sancto Andres (xxviii), Aucto de quando Sancta Helena hallo la cruz de Nuestro Señor (xxxiii), Auto del martyrio de Sancta Barbara (xxxvii), Aucto del martyrio de Sancta Eulalia (xxxviii), Auto de San Francisco (xxxix), Aucto de la prision de Sant Pedro (xlvii), Aucto de la visitacion de Sant Antonio a Sant Pablo (lxxvi), Aucto de la conversion de Sant Pablo (1xiii) and Auto del martyrio de Sant Justo y Pastor (xxix). The last was probably written by Alonso de Torres, and performed at the University of Alcalá in $\mathrm{r}_{568}$. In honour of the same festival, a Representacion de los martires Justo y Pastor was composed by Francisco de las Cuebas. A manuscript of the National Library of Madrid, which contains this play, furnishes valuable information concerning the construction of pageants and the use of stage machinery about the middle of the sixteenth century.

Twenty-six plays not already mentioned, and included in the manuscript published by Rouanet, treat Old Testament material, and it appears that those subjects were chosen which would serve to illustrate the close symbolic connection between Christ and the patriarchs of the Old Testament. The Auto del peccado de Adan (x1), Auto de la prevaricacion de nuestro

1 See J. P. W. Crawford, The Catalan Mascarón and an Episode in Jacob van Maerlant's Merlijn, Publications of the Modern Language Association of America, vol. xxvi, I9II. 
padre Adan (xlii), and the Auto de Cain y Abel (xli), the latter by the Valencian humanist Jaime Ferruz, treat of the Fall and the story of Cain and Abel, while the Auto de quando Abrahan se fue a tierra de Canaan (iii), Aucto de Abrahan quando vencio los quatro reyes (xxii), Auto del destierro de Agar (ii), Auto del sacreficio de Abraham (i) and Auto de los desposorios de Isac ( $\mathrm{v}$ and vi), treat incidents in the life of Abraham. The Aucto de quando Jacob fue huyendo a las tierras de Aran (iv), Aucto de la lucha de Jacob con el angel (xi), Auto del robo de Digna (viii), and Aucto del finamiento de Jacob (xii), deal with the story of Jacob. The Auto de los desposorios de Joseph ( $\mathrm{xx}$ ) describes an incident in the life of Joseph, and the Auto de los desposorios de Moysen (xlix) and Aucto del Magna (x) deal with Moses. It will be seen that these subjects correspond to the lectiones and responsoria in Septuagesima, Sexagesima and the Quadregesimal season. It is probable that most, if not all, of these plays were written for the Corpus Christi festival.

The remaining plays of this manuscript treating Old Testament subjects, namely, the Aucto de la ungion de David (xix), Auto de Naval y Abigail (lix), Auto de la muerte de Adonias (xxxvi), Auto de Sanson (xiii), Auto del rey Asuero quando desconpuso a Basti (xvi), Auto del rey Assuero quando ahorco: a Aman (xvii), Aucto de la lepra de Naaman (xviii), Auto del sacrificio de Jete (xxiv), Auto de la paciencia de Job (xcvi) and Auto de Tobias (xxi), represent a widening of the scope of Old Testament material for use in Corpus Christi plays.

The tendency toward allegory and symbolism, foreshadowed in the Farsa sacramental of López de Yanguas and in certain plays of Sánchez de Badajoz, prevailed in the second half of the sixteenth century, and these elements served as a basis for the further development of the autos sacramentales in the following century. Thirty-three plays of this type are included in the codex under discussion, and all of these refer to the Eucharist and the festival of Corpus Christi.

The Farsa sacramental de la residencia del hombre (ix) 
and the Auto de la residencia del hombre (1) recall by their juristic setting the Auto de acusacion contra el genero humano, but here it is not original sin, but $\sin$ in general, which must be expiated by contrition and penitence, and the author's aim is to explain the Eucharist rather than the doctrines of the Incarnation and Redemption. The Aucto de la Verdad y la Mentira (lv) Farsa del triunpho del sacramento (lxxxi), Farsa del sacramento de las tres coronas (lxxxii), Farsa sacramental de la fuente de la gracia (lxxxvi), and Farsa sacramental llamada Desafio del honbre (xc), describe the victory of the forces of good over evil. The Farsa del sacramento de Moselina (1xxviii), Farsa del sacramento de los tres estados (lxxxiii), and Farsa del sacramento de la entrada del vino (lxxxviii), contrast the Christian and Jewish dispensations.

There is little evidence to support the theory that the autos sacramentales were frequently employed in the sixteenth century as a weapon against Protestantism. Rarely do we find in these doctrinal plays even a reference to heresy. Only three plays in this codex are devoted primarily to a refutation of heterodoxy. The Farsa del sacramento de las cortes de la yglesia (lxviii), is a glorification of the Church militant as represented by the tribunal of the Inquisition, while hatred of Luther and his teachings finds expression in the Farsa del sacramento de Peralforja (lxxii) and Farsa sacramental de la: moneda (lxxxiv).

The symbolism of the Eucharist is described in the Farsa del sacramento del Amor divino (vii), Farsa del sacramento de los sembradores (lxx), and Farsa del sacramento llamada Prematica del pan (lxxv), which was rewritten by Timoneda with the title Aucto de la fee or La pragmatica del pan, and performed at Valencia in 1570 . Transubstantiation is the subject of the Farsa del sacramento (1xix), and the Evangelists and various saints are employed in the Farsa del sacramento (lxxxvii) and Farsa del sacramento de los quatro Evangelistas (lxxxix) to explain the Eucharist. The Colloquio de fide 
$y p s a$ (lxvi) is still another version a lo divino of the Coloquio de Fenisa, and the fragmentary Auto (1xvii) also has a pastoral setting.

It is difficult to discover the relationship to the Corpus festival of the Aucto del emperador Juveniano (xxiii), which is derived from a story of the Gesta Romanorum. The Aucta de los triunfos de Petrarca (lviii) gives a theological setting to the Trionfi of Petrarch, and the Farsa del sacramento de la esposa de los cantares (lxxiii) derives its inspiration from the Song of Songs. The Farsa del sacramento de la fuente de San Juan (1xxi) explains the Sacraments, and was rewritten by Timoneda and performed at Valencia in I570, with the title Aucto de la fuente de los siete sacramentos. The Farsa del sacramento del engaño (lxxiv) is derived from the Farsa del mundo y moral of López de Yanguas. The Farsa del sacramento del pueblo gentil (lxxiv) treats of the conversion of the sinner; the Farsa del sacramento del entendimiento niño (lxxxv) teaches that understanding is vain without a knowledge of God, and the Farsa del sacramento de Adan (xci) treats of redemption through faith.

The Farsa del sacramento llamada de los lenguajes (lxxx) is a linguistic medley, that reminds us of a scene in Torres Naharro's Comedia Tinellaria, and the Farsa del sacramento de los cinco sentidos (1xxix) anticipates Calderón in the allegorical use of the five senses in Corpus plays. The Farsa sacramental de las bodas de España (xcii) presents Spain as the champion of Catholicism. It was performed at Toledo on Corpus Christi day, I570, and its title refers to the projected marriage of Philip II to Anne of Austria. The Aucto de las donas que embio Adan a nuestra Señora (liii) recalls Gómez Manrique's Representacion del nacimiento de nuestro Señor in its use of the symbols of the Passion.

In the year 1575, eleven years after the appearance of his Tres comedias, Juan de Timoneda published two volumes of religious plays with the title Ternarios sacramentales. Four of these plays are in Castilian, and the remaining two were 
composed, for the most part, in Valencian. It is probable that Timoneda resumed playwriting as a consequence of the interest of Juan de Ribera, Archbishop of Valencia, in Corpus plays, with which he had become acquainted at Badajoz and Seville. Religious plays had been performed at Valencia for many years on Corpus Christi day, but these had been limited to scenes from the Old and New Testament, and were not utilized specifically for an explanation of the Eucharist. Timoneda's plays, therefore, in which this element was emphasized, constituted an innovation in that city. $\mathrm{He}$ only claims the two Valencian plays, Aucto del castillo de Emaus and Auto de la Iglesia, as original compositions, and for these we have no reason to question his authorship. With respect to the Castilian plays, he frankly states in the tities that they are revisions of earlier works, three of which are extant. The Aucto de la fuente de los siete sacramentos and Aucto de la fee are rifacimenti of the Farsa del sacramento de la fuente de San Juan and Farsa del sacramento llamada Prematica del pan, respectively, both of which are found in the codex published by Rouanet. The original of the Aucto de la oveja perdida, which treats the Parable of the lost sheep, is found in a play with the same title, preserved in manuscript form at the Academy of History of Madrid. Los desposorios de Cristo, which presents the Parable of the marriage of the king's son, is a revision of earlier plays that are not known to be extant.

The Danse macabré, which exercised a gruesome fascination throughout the Middle Ages, was treated dramatically by the Segovian Juan de Pedraza in his Farsa llamada Danza de la Muerte, published in $155 \mathrm{I}$, and composed in coplas de arte mayor. Here three characters, a Pope, king and a lady of questionable virtue are confronted by Death, and carried away by him in spite of their protests. The chief figure is the jovial shepherd who recites the prologue, and whose questions elicit from Reason an explanation of the mystery of the Eucharist. It is probable that the same author may be identi- 
fied with the Segovian, Juan Rodrigo Alonso, "que por otro nombre es llamado de Pedraza," who published in the same year the Comedia de Sancta Susaña, a pleasing dramatization in double redondillas of the familiar story found in the thirteenth chapter of the Book of Daniel.

The Auto de las cortes de la Muerte recalls Pedraza's Danza de la Muerte and Sánchez de Badajoz's Farsa de la Muerte, as well as the Sorrowful Knight's encounter with a troupe of strolling players who had just performed El auto de las cortes de la Muerte, as narrated in the eleventh chapter of the second part of Don Quixote. It was published in 1557 by Luis Hurtado de Toledo, who states in the prologue that he had completed the work which had been begun by Micael de Carvajal. We may assume that the greater part of this composition was written by Luis Hurtado de Toledo, for it is in no sense worthy of the author of the Tragedia Josefina. Death convokes a great assembly to which are summoned representatives of many social classes. Interminable dialogues are held in which Satan, World and Flesh present charges against the various characters, while St. Augustine and St. Francis serve as attorneys for the defense. The length of the play-about 8000 lines in double quintillas-seems to preclude the possibility of representation.

The same undramatic quality is found in the earliest play of Bartolomé Palau entitled Farsa llamada Custodia del hombre, in five jornadas, and published in $\mathrm{I} 547$. Composed in honour of the Corpus Christi festival, it contrasts in allegorical fashion the paths of virtue and evil, and contains in the first jornada a combination of the Processus Belial and Four Daughters of God themes, which we have seen in other plays. Far more important is Palau's Historia de la gloriosa Santa Orosia, in six autos, which was probably written about the middle of the century. This play has peculiar interest as the earliest dramatic composition in Spain dealing with national history. Its author, a native of Burbáguena, had a local pride in the story of Santa Orosia, who was held in especial veneration at Jaca, 
Huesca and Tarragona. According to the legend used by Palau, Roderic, the last of the Visigothic kings, sends an ambassador to Bohemia to ask for the hand of Princess Orosia. The latter sets little store upon worldly honours and longs to enter a convent, but she finally accepts the proposal of the Spanish king, which seems to offer certain advantages to her people. In the meantime, Roderic casts lustful eyes upon la Cava, who informs her father, Count Julian, of her violation by the King. The infuriated father summons the Moors to invade Spain, and it is a band of these Moslems that intercepts Orosia and her retinue who are on their way to meet the King. Orosia meets this ordeal with strength and constancy, preferring to die rather than yield herself to the enemies of her faith. There is considerable dramatic power shown in the interview between Roderic and la Cava, and the martyrdom of Orosia is effectively described. The play is pleasing in its combination of romantic and religious elements. Palau wrote another play, probably of a similar type, entitled Historia de Santa Librada y sus ocho hermanas, which is not extant.

The development of the Corpus Christi festival into a great civic holiday and the supervision exercised by the municipal authorities over the dramatic performances of that day, gave increased importance to the Corpus plays during the latter half of the century, at the expense of Christmas, Passion and Easter plays, which did not enjoy official support. Documents discovered, particularly in the archives of Seville, Madrid, Valladolid, Valencia and Badajoz, attest the importance attached by the municipalities to these performances, and we may assume that in other cities, and even in small towns, the celebration of Corpus Christi day was not considered complete without the procession of movable cars upon which members of the guilds or a company of strolling players presented a play or plays, more or less directly related to the mystery of the Eucharist. This practice even crossed the seas, for we know that religious plays were performed in the Colonies, both in the native languages and in Castilian. ${ }^{1}$

${ }^{1}$ References to these are found in an article by E. C. Hills entitled 
As elsewhere in Europe, religious plays were performed in Jesuit schools in Spain during the latter half of the sixteenth century to celebrate important Church festivals, particularly Corpus Christi. A Latin tragedy entitled Saul furens by Padre Dionisio Vázquez was performed at Plasencia in $1554,{ }^{1}$ under the auspices of the Jesuit Society, and the tendency, which later was to prevail, of introducing comic characters drawn from the lower classes of society, already appears in a play entitled Nineusis, comedia de divite epulone, probably by Juan de Valencia, a writer of the time of Charles V. Seven plays of the Jesuit, Padre Acevedo, some of which were in Latin, others in Castilian, and still others bi-lingual, were performed at Seville and Cordova between the years 1556 and 1572 . The same variety of language is found in the manuscript plays performed at Jesuit schools in the last third of the sixteenth century, and preserved at the Academy of History at Madrid. These plays, which deserve to be better known, present an interesting combination of sacred material, with entremeses after the manner of Lope de Rueda.

The Quechua Drama, Ollanta, published in the Romanic Review, vol. v, IgI4. See also F. A. de Icaza, Orígenes del teatro en México, Boletin de la Real Academia española, vol. ii, 1915.

${ }^{1}$ Cañete, Teatro español del siglo XVI, Madrid, I885, p. 137. 


\section{CHAPTER VIII}

\section{Tragedy and Later Comedy}

WHILE in general outlines the development of comedy in Italy and Spain followed parallel paths in the first half of the sixteenth century, Italy anticipated Spain by nearly sixty years in the composition of tragedies based upon classical models. The plays of Seneca had been translated into Castilian by the beginning of the fifteenth century, ${ }^{1}$ but there is no evidence that they awakened any desire to perform Latin tragedies at that time, either in the original or in translation. Spanish poets seem to have cared little about the traditions of classical tragedy, and they were slow to follow the example of Trissino and Giraldi Cinthio who introduced into Italy the theories and practice of Greek and Latin playwrights.

Even the incidents of Roman history offered little attraction to Spanish dramatists of the first half of the sixteenth century, and only two extant plays of that period, namely, the Farsa o tragedia de la castidad de Lucrecia and the Tragedia de los amores de Eneas y de la reyna Dido, treat such material. Little is known of the latter play, save that it was printed in I536. The former was written by Juan Pastor, author of a Christmas play printed in 1528 , and we may assume that the Tragedia de la castidad de Lucrecia belongs to approximately the same period. This play, composed in quintillas de pie quebrado and without division into acts or scenes, has nothing in common with classical tragedy. The scenes of the violation of Lucrece and her self-inflicted death are not without interest,

${ }^{1}$ For an account of the early Castilian translations of Seneca, see Mario Schiff, La Bibliothèque du Marquis de Santillane, Paris, 1905, p. 130. 
but are marred by the incessant impertinences of a bobo. It deserves attention only as a precursor of the plays of Juan de la Cueva on Roman history.

The Spanish translations of Greek tragedies in the sixteenth century seem to have had no influence upon the development of the drama. Hernán Pérez de Oliva made a free translation in prose of the Electra of Sophocles, published in 1528 with the title La venganza de Agamemnon, the first version of Sophocles in any modern language, and a translation of Euripides' Hecuba, with the title Hecuba triste, which was not printed until I586. It is likely that these translations were based upon Latin versions, since Pérez de Oliva nowhere refers to a knowledge of Greek. His purpose was not to make an accurate rendering of these masterpieces of Greek drama, but to prove that their lofty ideas might be adequately expressed in Castilian. He wished to communicate to his contemporaries the inspiration which he himself felt, and did not hesitate to alter the form in order to make his own versions more intelligible. He abandons the division into acts and the metrical structure, suppresses certain characters and changes the order of scenes, and replaces the traditions of Greek religion by moral atmosphere based upon Christian sentiments. Many of the beauties of his originals were lost in his adaptations, but his plays have especial interest as the first attempts to interpret the Greek drama to a Spanish audience.

Unhappily, his innovations had little effect upon the development of humanism in Spain. In 1543, the poet Boscán translated a play of Euripides, which was never printed, and Pedro Simón Abril, the translator of Terence, is said to have translated Plutus of Aristophanes and Medea of Euripides in 1570 . These close the list of translations or adaptations of classical tragedies in the sixteenth century. In view of the interest shown throughout Europe in the revival of Greek and Latin studies, it is surprising that not a single tragedy on classical lines is known to have been composed in Spain before $\mathbf{1 5 7 7}$, the date of publication of Nise lastimosa and Nise 
laureada, for which their author, Jerónimo Bermúdez, justly claimed the title of "primeras tragedias españolas".

The long controversy regarding the originality of Nise lastimosa may be regarded as settled, and it is now generally conceded that Bermúdez read in manuscript a play entitled Castro by the Portuguese poet and dramatist, Antonio Ferreira, and translated it almost line for line. Ferreira was born at Lisbon in 1528 , and studied at the University of Coimbra. Besides two comedies, Bristo and Cioso, based upon classical and Italian comedy, he wrote a considerable amount of verse in the Italian manner, which entitled him to rank second only to Sâ de Miranda among his contemporaries. At that time Coimbra had become the center of classical influences, chiefly owing to the famous Scotch humanist, George Buchanan, who not only encouraged the students to represent classical plays, but also showed his interest in the drama by composing two tragedies, Jephtes and Joannes Baptista, which were performed there in 1542 . It is to these college performances that we owe Ferreira's Castro, the first Portuguese tragedy composed according to classical models. In writing this play, he did not seek his material in Livy, as was so often done in Italy, but chose a familiar incident of Portuguese history of the fourteenth history. The chronicles told the sad story of Inez de Castro who suffered cruel death because of her love for the Infante Pedro, and who "despois de ser morta, foi Rainha". Camoens, who immortalized the story in the third canto of Os Lusiadas, refers to the living tradition in a superb stanza of his epic. The death of Inez de Castro has exercised a fascination upon poets and playwrights for centuries. It has inspired not less than ten Portuguese plays, and four in Spanish, the best known of which is Vélez de Guevara's Reinar despues de morir.

Ferreira's tragedy was written between 1553 and 1567 , during which time he was professor of law at Coimbra, and it was performed by the University students under his personal direction. The interest of the performance was doubtless 
enhanced by the proximity of the places mentioned in the play. From the hill overlooking the "saudosos campos" of the Mondego, the students could see the old Santa Clara Convent where Inez de Castro was interred before that solemn burial in the cathedral of Alcobaça, and also the lovely Quinta das Lagrimas and the tall cypress trees sheltering the Fonte dos Amores, where the lovers were wont to meet, and where, two hundred years before, Inez was put to death by the hand of assassins. Ferreira died of the plague at Lisbon in 1569 . His tragedy was not published until 1587 , although it had circulated freely in manuscript before that time. It appeared in a revised edition in 1598 .

Castro gives evidence of an intimate acquaintance with both Greek and Latin tragedy. The function of the chorus seems to be a compromise between the practice of Seneca and of the Greek dramatists. Stichomythia is frequently employed, and the rôle of the attendant of Inez betrays a classical origin. There are also a number of textual borrowings from Seneca, especially in the choral odes. However, Ferreira had the good taste to avoid the worst faults of the Latin dramatist, and he obtains his effects by simplicity, restraint and poetic language rather than by declamation and brutality. Whether it was due to his study of Greek drama or to his innate sense of propriety, the play is marked by a restraint which is refreshing to one who has been a witness of the scenes of carnage and bloodshed found in Seneca, Argensola, Virués and the Italian tragedies composed after the Orbecche of Giraldi Cinthio. The prevailing verse form is the verso solto of eleven syllables, with occasional lines of seven syllables, a measure which probably shows the influence of Trissino. The choral odes have rich metrical structure, including the canzone, sapphics, sapphics with adonics, and verso solto of seven syllables.

Bermúdez's version of Castro, entitled Nise lastimosa, together with Nise laureada, its continuation, was published at Madrid in 1577 under the pseudonym of Antonio de Silva. 
The plays were composed while Bermúdez was a reader in theology at the University of Salamanca, and they were completed by the year I575, the date of their dedication to the Count of Lemos.

The Spanish version, in which the heroine appears as Nise, an anagram of Inés, follows closely the Portuguese text, and adds no new incidents. The rôle of the chorus is restricted in the main to the singing of choral odes between the acts. A few changes were also made in the arrangement of scenes and there is evidence of independent borrowing from Seneca, especially from Phaedra. No line-by-line comparison, however, can give an adequate idea of the great superiority of the original over the translation. The work of the scholar, inspired by a love for the classics, is nearly always pleasing, but the theologian too frequently replaces the poetry and grace of the original by moralizing platitudes and vapid rhetoric.

In Nise laureada, Bermúdez displays his shortcomings as a dramatist when obliged to rely upon himself for inspiration. The theme is the disinterment and coronation of Inés de Castro after Pedro's accession to the throne, and the horrible death inflicted by him upon her murderers. The fate of the latter is a foregone conclusion, and each act is filled with wearisome monologues and interminable dialogues until the exitus horribilis at the close. Like the preceding, the play is divided into five acts, and the chorus not only serves to fill in the intermissions with choral songs, but also declaims during the action and occasionally engages in dialogue with the principal characters. Lack of restraint in the expression of grief and anger, far fetched figures of speech, sententiousness, the stoicism of the prisoners in the face of death, and the atrocious murders committed on the stage all indicate the influence of Seneca.

So far as we know, only one other tragedy definitely based upon classical models, the Elisa Dido of Virués, was written in Spain during the sixteenth century, and this was not published until 1609 . The experiment made by Bermúdez is of his- 
torical interest, but apparently contributed little to the development of the drama. Spanish playwrights refused to obey blindly classical precepts, and under the leadership of Juan de la Cueva, created a new type of play, which retained certain features of classical tragedy, but adapted them to meet the requirements of a Spanish audience.

Juan de la Cueva is the outstanding figure in the period of transition which preceded the appearance of Lope de Vega. Born at Seville about the year I550, he essayed nearly all the poetic genres, but it was not until after his return to his native city in 1577 , after a residence of over two years in Mexico, that he devoted himself to writing for the stage. His fourteen comedies and tragedies, published in 1583 and again in 1588 , were performed in various playhouses of Seville from I579 to I58I, and he also prepared for publication a second series of plays, of which nothing is known, save that in $\mathbf{I} 595$ he authorized two persons to secure a license to print this volume. Perhaps he realized that his plays could not compete successfully with the new type of comedia created by Lope de Vega. However, he seems to have cherished no resentment against his illustrious rival. It is true that he does not mention Lope in his treatise on poetics, entitled Exemplar poetico, completed in 1606, but he was generous enough to ardently defend the practice of the dramatists of the early years of the seventeenth century.

In this work, he attempts no defense of his own plays, written nearly thirty years before, but quite properly claims a share in the triumphs of his successors. While we must regard as unfounded his statement that he was the first to bring kings and gods on the comic stage, that the name jornada. was his own invention and that he had reduced the conventional five acts to four, there can be no doubt that he established the vogue of the four-act play between I 580 and 1585 , and that he gave the weight of his authority to the use of a variety of meters in a single play.

So little is known concerning the immediate predecessors of 
Juan de la Cueva on the Sevillan stage that it is impossible to determine whether these innovations are due to him alone. In his Exemplar poetico, he mentions Guevara, Gutierre de Cetina, Coçar, Fuentes, Ortiz, Mexía and Mal Lara as dramatic poets who had followed the older traditions of the stage at Seville. With respect to their dramatic work, we know practically nothing, and Cueva gives us specific information only concerning Juan de Mal Lara, who, are told, composed a thousand tragedies in which he altered ancient practice to conform with modern requirements. From other sources we learn that while still a student at Salamanca Mal Lara wrote, first in Latin, and later in Castilian, a comedy entitled Locusta, performed in 1548 , and that he was also the author of a tragedy entitled Absalon, and of an allegorical comedy performed at Utrera in $156 \mathrm{I}$. These, apparently, were school plays, and seem to have little relationship with the dramatic compositions of Juan de la Cueva. It is significant of the interest taken in the drama that when Cueva began to write, there were three corrales at Seville, the Corral de Don Juan, the Corral de las Atarazanas and La Huerta de Doña Elvira, and in these playhouses, the comedies and tragedies of Cueva were performed by the well-known actors Alonso Rodríguez, Alonso de Capilla, Pedro de Saldaña and Alonso de Cisneros.

Of the fourteen plays, three deal with epic material of Spain. The Comedia de la muerte del rey don Sancho y reto de Zamora presents one of the most celebrated incidents related in the chronicles and ballads. This story is a part of the Cid legend, and while the Cid himself plays a very secondary rôle, his spirit permeates the whole composition. The play consists of a series of scenes taken from the chronicles; the siege of Zamora by King Sancho and his death at the hands of the traitor Vellido Dolfos, who escapes to the city; the challenge of Diego Ordoñez to the defenders of Zamora; the acceptance of the challenge by the aged Arias Gonzalo; the death of his three sons in single combat; the death-struggle between Arias Gonzalo and Diego Ordoñez and the final award, 
and the dramatist limits himself to arranging his material and introducing dialogue. These characters of heroic mould win our interest and sympathy, and we can imagine the delight of an audience in seeing on the stage a story with which they were familiar and in hearing ballads recited which they had known from childhood, as for example, the famous challenge of Don Diego to the defenders of Zamora.

Even better known was the story treated in the Tragedia de los siete infantes de Lara, derived from La estoria del noble canallero el conde Fernan Gonzalez con la muerte de los siete infantes de Lara. ${ }^{1}$ Cueva failed to reproduce the sombre beauty of the legend, and its violation of the unities of time, place and action, is glaring. It is probable that Cervantes had this in mind when he spoke in Pedro de Urdemalas of a play in which twenty-odd years elapsed between the first and second act. $^{2}$ Instead of concentrating the interest upon the vengeance taken by Mudarra for the death of the seven infantes, three fourths of the play is occupied with the exposition. The story was a favorite one with later dramatists, and in the hands of the Duque de Rivas furnished material for the first decisive victory won by Romantic poetry in the third decade of the nineteenth century.

The third of the chronicle plays is the Comedia de la libertad de España por Bernardo del Carpio, which follows closely the account given in the Crónica general. The figure of Bernarda del Carpio, the national champion, who was credited with having turned back the invading French knights at the battle of Roncevaux, has ever been popular in Spain, and his exploits were sung in ballads and related in many a long-drawn-out epic poem. First brought on the stage by Juan de la Cueva, he appears again in the Casa de los celos y selvas de Ardenia of Cervantes, and in two plays of Lope de Vega, Las mocedades de Bernardo and El casamiento en la muerte.

${ }^{1} \mathrm{R}$. Menéndez Pidal, La leyenda de los Infantes de Lara, Madrid, I8g6, p. I25.

2 Menéndez Pidal, op. cit., p. I22. 
These three plays constitute a real innovation in the history of the Spanish drama. Juan de la Cueva was the first dramatist to make use of the legendary lore of Spain, to bring Spanish heroes on the stage, and to avail himself to any considerable extent of the rich treasure offered by the ballads. In his use of historical material, Juan de la Cueva is a true precursor of Lope de Vega.

His chief fault was the failure to distinguish clearly between the nature of epic and dramatic poetry. Some observance of the unities would have forced him to knit his scenes more closely together and to limit the time of the action, but respect for the unities did not enter into his conception of the drama. Many of the scenes have dramatic interest, but in most cases he failed to realize their relationship to each other, or to the play as a whole. His characters are over-fond of declamation and have scarcely a human quality. The dialogue is forced and unnatural, and never creates the illusion of ordinary conversation. The metrical forms most frequently employed by him, namely, verso suelto of seven and eleven syllables, octava rima and redondillas, give to the plays an epic or lyrical, rather than dramatic, quality.

It is difficult to determine what distinction the poet made between the terms tragedy and comedy. The Comedia del rey don Sancho and Comedia de la libertad de España may be called comedies because of their happy ending, that is to say, the vindication of the defenders of Zamora and the final triumph of Bernardo, but applying the same criterion, the Tragedia de los infantes de Lara is also a comedy, since it ends with the victory of Mudarra.

Cueva also wrote three plays dealing with early Greek and Roman history. The first of these is the Tragedia de la muerte de Ayax Telamon sobre las armas de Aquiles, which describes in disconnected scenes the departure of Aeneas from Troy, and the contest between Ajax and Ulysses for the arms of Achilles, as narrated in the thirteenth book of the Metamorphoses. The Tragedia de la muerte de Virginia y Appio Claudio, 
based upon the story familiar to us in the third book of Livy, has far more dramatic interest. The scenes are arranged so as to form a real plot, and the dénouement, which presents the heroism of Appius to save his daughter's honour, is effective. The Comedia de la libertad de Roma por Mucio Cevola lacks dramatic unity. The play was written merely as a setting for the scene in which Scævola proves to Porsenna the sort of courage possessed by the defenders of Rome, whom he proposed to enslave. In his use of classical historical material, Cueva anticipated Cervantes and many a dramatist of the following century.

His inability to realize the difference between a series of dramatic incidents and a plot with dramatic unity is well illustrated by the Comedia del saco de Roma, which offers the novelty of dealing with modern history. The action extends from the sack of Rome by the Duke of Bourbon in May, 1527, until the arrival of the Emperor for his coronation at Bologna in February, I530. Since Bourbon meets his well-deserved death in the second act and the emperor does not appear until the close of the fourth, the play has no real protagonist. The author's purpose seems to have been to attempt to arouse a feeling of righteous horror at this unholy undertaking by the accumulation of episodes designed to show the cruelty of the Spanish and German troops.

The Comedia del principe tirano presents the Prince Licimaco, whose jealous hatred of his sister, Eliodora, is stirred to action by the Fury Alecto and by the suggestions of his counsellor, Trasildoro. He determines to kill her, and this brotherly act is performed in the garden of the palace, while the Fates spin and cut the thread of her life. Trasildoro is also put to death in order that the secret of this crime may be guarded. The Prince and his father are pursued by gruesome visions at night, and finally the ghosts of Eliodora and Trasildoro reveal to the King the bloody deed of the Prince. The latter is condemned to death, effects his escape and is finally pardoned by the King. The second part, entitled Tragedia 
del principe tirano, is a perfect riot of bloodshed and crime. The estimable young Prince develops into a monster incarnate after his father's abdication. He burns the books of the Law, demands of reputable citizens the surrender of their daughters, executes any one who ventures to oppose him, buries two of his adversaries alive, and finally meets his death at the hands of two women whom he had sought to injure. There is nothing to justify this tissue of crimes, except the old moral lesson that the way of the transgressor is hard. All of the imitators of Seneca revelled in excesses of this kind, but this play passes the bounds of propriety and credibility.

The Comedia del tutor is an insignificant comedy of intrigue, dealing with the rivalry of two students, and the guardian of one of them, for the love of a young woman of Seville. Through the aid of his servant, Otavio plays a trick upon his rivals, and completely discredits them. Otavio is another $\mathrm{Ca}$ listo; Licio plays the part of a resourceful Sempronio, and Astropo, an engaging braggart, also recalls the Celestina. The plot is buried beneath diction and rhetoric, and the verse measures employed are too ponderous for a farce.

The Comedia de la constancia de Arcelina is an extravagant play, made up of characters and incidents that never existed except in a distorted imagination. One ridiculous situation follows another until an absurd dénonement is reached, which violates every law of probability. The plot of the Comedia del viejo enamorado has certain dramatic possibilities, but is spoiled by extravagant incidents. The intrigue by which old Liboso seeks to win the love of Olimpia is good material for a farce, but the later scenes, with the intervention of a magician and the Furies, are preposterous.

Far superior to these is the Comedia del degollado, which has interesting points of similarity with Whetstone's Historye of Promos and Cassandra, and with Measure for Measure. Its source seems to be the well-known fifth novella of the eighth Decade of Giraldi Cinthio's Gli Hecatommithi, or the latter's dramatization of the same story entitled Epitia, but 
the romantic incidents of the capture of Arnaldo and Celia create an original setting. Here Arnaldo's offense is a murder which is morally justifiable. In Giraldi's story, in Epitia and in Promos and Cassandra, the young girl actually sacrifices her honour to save her brother's life. This sacrifice is avoided in Measure for Measure by the substitution of Mariana for Isabella, and in El degollado, by the rather tardy repentance of the Prince. Arnaldo is more courageous than his counterpart in the other versions, for he refuses to live at the cost of Celia's virtue. In Giraldi's story, Epitia and Promos and Cassandra, the heroine not only marries her violator, but saves him from the death he so richly merited. Judged from modern standards, a satisfactory solution was found only by Shakespeare and by Cueva.

The Comedia del infamador is a comedia de capa y espada, with the addition of extravagant mythological and supernatural elements. While it is unlikely that it served as a model for the composition of Tirso de Molina's El burlador de Sevilla, as was claimed by Schack, its theme has a remote connection with the Don Juan legend. The influence of the Celestina is also apparent. There is a certain amount of interest in the early part which deals with the efforts of the dissolute Leucino to secure possession of Eliodora, and the latter's defense of her honour. The conclusion, however, brought about by Diana's assertion of the girl's innocence, and her command that Leucino be buried alive, after the river Guadalquivir refuses to receive his body, is ridiculous. As in the case of the Comedia del viejo enamorado, a plot with dramatic possibilities was spoiled by the introduction of absurd incidents.

A desire to protect Spanish tragedy from the restrictions imposed by classical traditions is apparent in the tragedy of Los amantes by the Valencian poet, Andrés Rey de Artieda, published at Saragossa in I58I. Born at Valencia in I549, he took his baccalaureate at the University of that city in 1563 , and studied law at Lérida and Tolosa. A soldier by profes- 
sion, who spent many years in the armies of Philip II and Philip III, and a comrade in arms of Cervantes at the battle of Lepanto, where he received three wounds, he devoted his leisure time to the writing of verse. When he was only fifteen years old, he was mentioned as a poet by Gaspar Gil Polo, and in his later years, he was a prominent member of the Academia de los Nocturnos. In addition to Los amantes, Valencian bibliographers have attributed to him two plays, El principe vicioso and Amadis de Gaula, of which nothing is known, and another play, Los encantos de Merlin, ascribed to him by Rojas Villandrando, is not extant.

In an epistle which precedes Los amantes, he contrasts the magnificence of the theatres of ancient times with the meager stage setting of his own day. "Now there is no trace", he says, "of the choral songs, although I saw them in print, not many months ago, in two Nises", in which he refers to the tragedies of Jerónimo Bermúdez, published in 1577 . But while aware of the beauties of the classical drama, he does not resign himself to follow blindly its traditions. He says that, judged by ancient standards, his play may be lacking in good taste, but this is a fault from which the ancients themselves could not always escape. He believes that tragedy has a right to adapt itself to modern conditions. While I do not believe that the poet's reference to the tragedies of Bermúdez, published in 1577 , proves that the dedicatory epistle of his own play was written as early as 1578 , since he may not have seen these immediately after their publication, I find littie evidence of acquaintance with the plays of Juan de la Cueva.

The subject of Los amantes is the well-known legend of the lovers of Teruel which was especially familiar to a Valencian audience. About the year I555, Pedro Albentosa, a native of the neighbouring town of Teruel, had published the Historia lastimosa $y$ sentida de los dos tiernos amantes Marcilla $y$ Segura, naturales de Teruel, and in 1562, Diego Ramírez Pagán mentioned Ysabella and Marcilla among the celebrated lovers in a composition included in his Floresta de varia poesia. 
Whatever the origin of this story may have been, whether based upon popular traditions, or upon a real occurrence, or upon a tale of the Decameron, this pathetic couple had become completely identified with Teruel when Rey de Artieda composed his pay. Thanks to Los amantes, and the pretentious epic of Juan Yaguie de Salas, and to the plays of Montalbán, Tirso de Molina and Hartzenbusch, not to speak of countless less well-known versions, Isabel and Marsilla have become paragons of frustrated love which finds an issue in death.

The originality of Rey de Artieda does not lie, therefore, in the invention of a plot and in the arrangement of dramatic situations, but in his choice of a national story replete with romantic incidents. His play is a tragedy, but, as he writes in his dedication, it does not deal with kings and princes. $\mathrm{He}$ presents "only a gentleman and lady, who strive to win Laura's laurel". This reference is not without interest, because he shows his admiration for Petrarch by translating, in the third scene of the second act, the well-known sonnet "Cesare, poi ch '1 traditor d'Egitto," which was also translated into Spanish by Hernando de Acuña. The earlier Spanish drama offers us no serious portrayal of love with its fatal consequences when thwarted. Here is represented the painful conflict between duty and will in the heart of Isabel, and the grief of the lovers, gradually intensified throughout the four acts. In the comedias of Tirso de Molnna and Pérez de Montalbán on the same subject, the biographical method is employed, while in Los amantes, emphasis is laid upon the crisis. Our sympathy is awakened by the moral struggle of the lovers against fatality, from which death affords the only possible escape.

With all these commendable qualities, the play cannot be regarded as a success. Tragic and commonplace elements too often stand side by side, and the scenes and characters employed to give comic relief frequently mar the unity of impression. The style is sometimes obscure, and the author unfortunately conceived of each act as a separate dramatic entity, a 
fault that he shared with nearly all of his contemporaries. $\mathrm{He}$ was conscious that Spain needed a new form of dramatic art, and his attempt to meet this need has historical interest, but he was lacking the genius to definitely indicate the path that the new drama must take.

The consuming love of Antony for Cleopatra, a favorite theme for dramatists for four hundred years, is portrayed in Marco Antonio y Cleopatra, a tragedy by the Licentiate Diego López de Castro, preserved in an autograph manuscript of the year I582. Nothing is known of the author, save that he was a native of Salamanca, and that he signed the autograph copy of the play at Madrid. The first two acts, which present the jealousy of Flaminio, his betrayal of Antony and the madness of Marcela, appear to be original, but the last two acts are derived from Plutarch, and offer interesting analogies with Shakespeare's Antony and Cleopatra. The suicide of Heros is dramatically and tenderly presented, and there is almost a Shakespearian note in Cleopatra's anguish when she sees the lifeless body of Antony. "Surely he is dead", she cries, "since he hides from me his face". Cleopatra's death follows immediately upon this scene, and the play ends with Octavian's tender tribute to her beauty and charm.

This play has a human interest which is absent from the tragedies of Juan de la Cueva. Antony is not a pseudoheroic type, but merely a weak man dominated by an unscrupulous and vacillating woman, and the sinister influence of Cleopatra upon his life is intelligible and awakens sympathy. We may criticise the constant shifting of the scene from Rome to Alexandria, and we may find that the first two acts are unconvincing and unnecessary, but in his use of Plutarch's story in the last two acts, we must credit López de Castro with true dramatic sense and a lyrical talent of a high order. The influence of Juan de la Cueva may be seen in the division of the play into four acts, and in its variety of metrical forms.

A far less successful attempt to imitate the methods of Cueva is found in an anonymous romantic comedy entitled 
Los cautivos, preserved in an undated manuscript. The youth Ylioneo has abducted his sweetheart Lucela, and the maiden adopts the disguise of a man in order to escape detection. They are captured by highwaymen and sold to corsairs who carry them off to Carthage. Since they have different masters they can see each other only with great difficulty, and to make matters worse, the daughter of Lucela's master falls in love with her, believing her to be a man. The dénouement is reached in the fourth act. Rosiana persists in her advances to Lucela and, angered by the latter's indifference, charges her with attempting to do her violence, and Lucela is consigned to prison. When the latter appears for trial, she succeeds in proving her innocence by revealing her identity, the lovers are promised their release, and are forgiven by their fathers who arrive opportunely on the scene.

'The theme of a young girl masquerading as a man, either from choice or necessity, was a favorite one in sixteenthcentury fiction and plays, and the ingenuity of novelists and dramatists was taxed to contrive new complications arising from this disguise. In a number of cases the disguised lady awakened love in the heart of another woman, as in the love of Phebe for Rosalind, but rarely did this situation have tragic possibilities. This central incident in Los cautivos bears a marked resemblance to a scene in Calderón's El José de las mujeres, and another analogue is found in Lope de Vega's Las Batuecas del Duque de Alba. Los cautivos contains the elements of a good plot, of which the author signally failed to avail himself, except in portions of the fourth act. The style is mediocre, even when due allowance is made for the lamentahly incorrect text that we possess.

The Comedia Salvaje of Joaquín Romero de Cepeda, published at Seville in 1582 , is the last of the sixteenth-century dramatizations of the Celestina. The author was a native of Badajoz, and wrote the Comedia Metamorfosea, as well as a considerable amount of lyrical verse. The Comedia Salvaje consists of four short acts, written in double redondillas, and 
shows no acquaintance with the plays of Juan de la Cueva. The first two acts, which deal with the abduction of Lucrecia by Anacreón with the aid of the bawd Gabrina, faithfully reproduce familiar incidents of the Celestina and are acceptable, but the attempt to show the consequences of wrong-doing in the last two acts cannot be taken seriously. The play represents an unsuccessful effort to combine the comedy of manners with the pastoral drama.

In discussing the predecessors of Lope de Vega in his Loa de la comedia, Rojas Villandrando mentions Francisco de la Cueva as the author of El bello Adonis. This play has been lost, but the National Library of Madrid preserves an autograph manuscript of the same writer's Tragedia de Narciso. Francisco de la Cueva y Silva was born at Medina del Campo about the year $\mathrm{I} 55^{\circ}$, and his two mythological plays were probably written before he reached middle life. "He wrote plays that were performed with general applause", wrote Lope de Vega in the Dorotea. Later, he seems to have given up playwriting and to have devoted himself to the practice of law. He became one of the foremost jurists of his time, and the poets speak of him as a marvel of learning. When he died in 1628, Quevedo wrote a sonnet in his memory, and Lope de Vega bade a last farewell to his life-long friend in the Laurel de Apolo.

The Tragedia de Narciso treats the familiar story of Echo and Narcissus as related in the third book of the Metamorphoses. It is divided into four acts, and shows a rich variety of metrical forms. The author seems to have possessed greater lyrical than dramatic talents, but the play is characterized by good taste, and the description of the death of Narcissus is effective. It is also interesting as a unique example of the dramatic use of mythological material, which was destined to become so frequent in the Court productions of the seventeenth century.

The anonymous Gran comedia de los famosos hechos de Mudarra, written in 1583 or 1585 , and preserved in a manu- 
script at the National Library of Madrid, deals with the legend of the Infantes de Lara, already brought upon the stage by Juan de la Cueva. The author avoids the multiplicity of incidents which formed the basis of the latter's play, and restricts the action to Mudarra's vengeance. Familiar ballads were skilfully introduced to supplement the narrative of the chronicles, and truly dramatic situations are not lacking. The play is divided into three acts, and the redondilla is the prevailing measure.

In a conversation introduced into the forty-eighth chapter of the first Part of Don Quixote, Cervantes discusses with some resentment the infatuation of theater-goers for nonsensical plays that violate all the laws of art. He says that perhaps actors and managers underestimate the literary taste of theatrical audiences, and recalls that a few years before "there were three tragedies acted in Spain, written by a celebrated poet of these kingdoms, which were such that they filled with admiration, delight and amazement all who heard them ... . and brought in more money to the actors, these three alone, than thirty of the best subsequently produced". These three plays were La Isabela, La Filis and La Alejandra, and they found favour with their audiences, in spite of the fact that they observed the principles of art.

These plays, written by Lupercio Leonardo de Argensola, were not included in the edition of the poet's works published at Saragossa in 1634, and were known only by the reference in Don Quixote until the year $177^{2}$ when two of them, Isabela and Alejandra, were included in his Parnaso español by López de Sedano, who preserved the division into three acts found in the manuscript which he used. The Conde de la Viñaza followed López de Sedano's text in his edition of these plays, and also printed variants from a manuscript preserved at the National Library of Madrid, in which they are divided into four acts. That the latter was the original form is proved by the prologue to Alejandra, in which Tragedy mentions among the innovations of modern drama the reduction of the five acts 
of the classical theatre to four. They were probably written between I58I and $\mathrm{I}_{585}$ for presentation at Saragossa. The prologue to Alejandra contains a specific reference to that city, and Isabella has Saragossa as its scene of action and contains numerous appeals to local patriotism.

The prologues to the plays furnish conclusive proof that while Argensola was not a strict classicist in his conception of tragedy, he had little sympathy with the Spanish popular drama. Isabela is introduced by the allegorical figure of Fame who, after apologizing for violating the laws of tragedy by appearing in a public theatre, congratulates the audience upon its good judgment in prefering pitiful tragedies with a moral lesson to lewd nonsense that pleases the masses. The prologue to Alejandra is recited by Tragedy herself who explains her ancient and honorable lineage. The learned Aristotle had made rules for her adornment, but time had intervened, depriving her of one of her five acts, and of the choral songs as well. She expresses her surprise at seeing the spectators so attentive, and bids them prepare for the war, deaths and tears that are to follow.

The action of Isabela is laid at Saragossa, in the reign of Peter I of Aragon. The conflict between Moors and Christians forms the background, and the plot revolves about the passion of the Moorish king, Alboacén, for the Christian maiden, Isabela. It is a romantic tragedy, conceived after the manner of the Italian imitations of Seneca rather than based upon a close study of the Latin dramatist. The unities of place and time are observed, but the unity of action is flagrantly disregarded. The central point is the determination of Isabela to die with her lover Muley, a convert to Christianity, rather than yield herself to the enemy of her people. The generous attempt of Isabela to sacrifice herself for her lover recalls the episode of Olindo and Sofronia in the Gerusalemme Liberata, which Argensola may possibly have known, and also the storr of Nisus and Euryalus in the ninth book of the Aeneid, a few lines of which were translated by the poet 
in describing the death of Isabela. The latter is a martyr of the type that has made Saragossa famous, and the inspiration of the play is almost exclusively national.

The tragedy of Alejandra has two well-defined actions: the desire of a prince to avenge his father's death, and the insane jealousy of a king which finds satisfaction in the death of his queen, thus combining the themes of Hamlet and Othello. The latter part of the play, including the jealousy of King Acoreo and his bloody revenge upon the queen and an innocent courtier, is based upon Lodovico Dolce's Marianna, a dramatization of the world-famous story of Herod and Mariamne, as related by Josephus. The court of one of the Egyptian Ptolemies, which the author chose for a background, was well adapted to the gruesome incidents here presented. After being obliged to wash her hands in the blood of the man she loves, Alejandra drinks poison, bites off her tongue in her agony and spits it at the king; children are ruthlessly murdered; Acoreo is assassinated by members of his own escort, who offer his head to Orodante and are executed as traitors; Sila stabs Orodante and then commits suicide, and although the ghastly execution of Lupercio is mercifully described by a messenger, Argensola even surpasses Dolce in the element of physical horror.

In adapting the Italian play, Argensola made a number of important changes. Marianna is entirely innocent of infidelity; Alejandra is unfaithful, at least in thought. The cup-bearer, who is merely an instrument in the conspiracy in Dolce's tragedy becomes a prominent character in Alejandra as claimant to the throne. Marianna ends with the repentance of Herod for the execution of Soemo, Marianna, Alessandra and his two sons. In Alejandra, the death of Acoreo at the hands of the conspirators furnishes the denouement. The sub-plot, including the love of Lupercio and Orodante for Sila, as well as the conspiracy of Ostilo and Rémulo, seems to be entirely of Argensola's invention.

It is easy to ridicule the horrors of this play, but we should 
not forget that melodrama, with scenes of bloodshed, was a natural inheritance from Seneca, and that Alejandra should not be compared with the plays of Lope de Vega and Tirso de Molina, but with The Spanish Tragedy, with Giraldi Cinthio's Orbecche and with the tragedies of Robert Garnier, all of which represent approximately the same stage of dramatic development as the plays of Argensola.

In the prologue to his Ocho comedias $y$ ocho entremeses (I6I5), Cervantes chats half playfully and with a touch of sadness concerning his early plays, written before Lope de Vega directed the Spanish drama into new paths. He tells us that in the first period of his dramatic activity, he composed from twenty to thirty plays, of which he mentions specifically Los tratos de Argel, La destruccion de Numancia and La batalla naval, and adds whimsically that all of these were performed without any offering of cucumbers or other sign of disapproval from the audience. In the Adjunta al Parnaso, published the preceding year, Cervantes mentions among his early plays Los tratos de Argel, La Numancia, La gran Turquesca, La batalla naval, La Jerusalen, La Amaranta o la del Mayo, El bosque amoroso, La unica y la bizarra Arsinda, "and many others which I have forgotten", and expresses his preference for still another, entitled La confusa. Of these early plays, only two are extant, Los tratos (or El trato) de Argel and La Numancia, which were first published in 1784 , and which, on the basis of their order in the two lists, were probably the first dramatic compositions of Cervantes. With respect to La confusa, we know, thanks to the discovery of Pérez Pastor, that while residing at Madrid in 1585 , Cervantes contracted with a theatrical manager to write two plays entitled La confusa and El trato de Constantinopla y muerte de Selin. We do not know whether the latter was ever performed or even written, since Cervantes did not include this title in either list.

${ }^{1}$ This title may stand for two plays. 
"Of the captivity and deeds of Miguel de Cervantes, a separate history might be written", says Diego de Haedo in his Topografia $e$ historia general de Argel (1612). Even more interesting than such a history, had it been written, are the three novelas and the two plays, Los tratos de Argel and Los baños de Argel, in which Cervantes drew largely upon his own experiences during his five years of slavery. With the memories of his own hardships fresh in his mind, he attempted to describe in Los tratos de Argel the sufferings of the Christian captives in Algiers, and drew a picture that must have been painful to his audience. One could not see with equanimity the courageous efforts to escape that were rewarded by death; the apostasy of men of weaker stuff; the ruthless disregard of Christian womanhood, and the martyrdom of Christian priests; nor could one witness without righteous anger the scene of the slave-market, where members of the same family were sold to the highest bidders and separated from one another, condemned to a living death. The purpose of Cervantes was to prick the conscience of Philip II, who was more interested in extending the faith in Flanders than in relieving the sufferings of his own captive subjects, or in ridding the Mediterranean of an ever-present nuisance; and in an eloquent outburst in the first act, he pleads for those captives, introducing verses which he had directed to the Secretary of State, Mateo Vázquez, in 1577.

The plot and characters are completely overshadowed by the absorbing interest of the background. The trials of the lovers, Aurelio and Silvia, which recur in El amante liberal, become insignificant when compared with the misery of their companions in slavery. Cervantes did not understand at that time the art of arranging dramatic scenes. The construction is loose, and, as a play, it cannot be accorded high rank. However, as a picture of some of his own experiences during. five years, as a cry of anguish from the heart of a great man, and as an appeal to remedy conditions that were a disgrace to Christendom, it deserves our respect and admiration. Among 
the differences noted in the two manuscripts in which the play has been preserved, the most noteworthy is that in one of these it is divided into four acts, and in the other, into five acts. The original version was undoubtedly in four acts.

The play contains a reference to the preparations of Philip II for the conquest of Portugal and to a review of the Spanish and foreign troops at Badajoz, which was held in May, 1580 . At the end of the play, mention is made of the arrival in Algiers of certain Trinitarian Fathers, which actually took place in May 29th of the same year. From these allusions, it has been suggested that Los tratos de Argel was written at Algiers in the summer of $1580 .^{1}$ Does it follow that the play was written during his captivity merely because Cervantes placed the action in the year of his release, and gave it verisimilitude by introducing historical references? If we accept the date proposed, we must explain as a mere coincidence the similarity of Los tratos de Argel to the plays of Juan de la Cueva. It seems more reasonable to assign the composition of this and the other plays mentioned in the prologue to his Ocho comedias to the period between 1581 or 1582 and 1587 , when Cervantes was living in or near Madrid.

La Numancia (or La destruccion de Numancia), in four acts, presents the heroic defense made by the city of Numantia against the Romans, culminating in its capture in $133 \mathrm{~B}$. C. by Scipio Aemilianus. Cervantes may have read the details of this famous campaign in the histories of Appian or Florus, or in the continuation of Florián de Ocampo's Crónica by Ambrosio de Morales. He showed good judgment and secured a semblance of dramatic unity by focusing his attention upon the death-agony of the city that dared defy the might of Rome.

The play begins with the arrival of Scipio as commander-inchief, his refusal to discuss peace terms with the Numantians, and his determination to starve them into submission and to

${ }^{1}$ El teatro de Cervantes, estudio crítico por Armando Cotarelo y Valledor, Madrid, 1915, p. 192. 
destroy the city. The gradual exhaustion of the defenders in their struggle against hunger is painfully described, and when Scipio finally succeeds in entering the city, he finds himself deprived of the chief fruits of his victory. Only heaps of corpses and desolation meet his eyes. He offers wealth and liberty to a youth who has mounted a tower of the wall with the keys of the city, but the brave Numantian hurls himself from the tower, thus depriving Scipio of the glory of taking a captive to Rome as a symbol of his victory.

Many of the incidents, such as the love of Morandro and Liria, and the brave attempt of Morandro and Leoncio to secure food in the Roman camp, claim our interest and sympathy, but it must be admitted that the play has epic rather than dramatic qualities. The introduction of the personified figures of War, Famine, Spain, Disease, the River Duero, and others, upon which Cervantes later prided himself, detracts from the impression of reality which he sought to create. It is the sombre background that enlists our respect and admiration. To Cervantes, the Numantians were the forebears of his own people and their bravery represented the defense of Spain against a foreign invader. The play is the best literary expression that we possess of Spanish patriotism at the close of the sixteenth century.

Like Rey de Artieda, a veteran of Lepanto and of many a battle-field in Italy and Flanders, and like him a Valencian, Cristóbal de Virués published five tragedies at Madrid in the year r609. We have little evidence for determining the date of their composition, but the fact that they were undoubtedly earlier than the first plays of Lope de Vega, and show an acquaintance with the theatre of Juan de la Cueva, allows us to conjecture that they were written between 1580 and 1585 . Four of these plays were composed in three acts, an innovation for which he claimed priority in the prologue to his $L a$ gran Semiramis, and this claim was supported by Lope de Vega in his Arte nuevo de hacer comedias en este tiempo.

${ }^{1}$ The Comedia Florisea of Avendaño, in three acts, was published in 
In the tragedy of Elisa Dido, Virués proposed to write a play " entirely after the manner of the Greeks and Romans, with care and study". His imitation was limited to the most superficial features: the division into five acts, the use of the chorus, the exclusion of comic elements, and characters with a fondness for declamation. In common with most of the Italian dramatists of his time, and Bermúdez as well, he adopted hendecasyllabic verso suelto as the basis of his verse. While the main outlines of this play on Dido are derived from the historical account contained in Justin's Historiae philippicae, the poetical narrative of Vergil also contributed a few incidents.

At the beginning of the play, Dido is aware of the ambitious plans of Iarbas, and accepts the proposal of marriage made by his emissary. Her reply is a diplomatic lie, and the interest is concentrated upon this fallacious answer and her suicide in the presence of her suitor. Iarbas himself does not appear until the dénouement and the heroine's rôle occupies only about one hundred lines. Unfortunately, the author tried to make the plot more complex by introducing two Carthaginian chiefs, Seleuco and Carquedonio who are enamoured of Dido, and who in turn have awakened love in the hearts of Ismeria and Delbora. He attempted to heighten the interest by the introduction of irrelevant episodes, and was totally unable to focus his attention upon a logical sequence of incidents.

We do not know the date of Elisa Dido, but it is certain that La gran Semiramis is the first of his three-act plays. $\mathrm{He}$ tells us in his preface that in these four tragedies he attempted to reconcile classical art and the practice of contemporaneous writers, taking from each its best elements, and thus satisfying the requirements of modern art. It is charitable to assume that this preface was written many years be-

I55I, but this does not invalidate the claim of Virués. The Spanish plays with which he was acquainted were written in four acts, and he had good reason to believe himself the inventor of a new form. 
fore its publication in 1609 , for it is inconceivable that Virués could have expresed himself with such complacency had he been acquainted with the comedias of Lope de Vega, or even with the development of the drama in his native city of Valencia.

"In all my plays", wrote Virués, "although written for my own amusement and in my youth, heroic and grave moral examples are shown, as befits their grave and heroic style". He shared Giraldi Cinthio's conception of the moral function of tragedy and followed his example by attempting to deter men from $\sin$ by showing its terrible consequences. He did not concern himself, however, with the petty sins that are within the reach of any man. In order to strengthen the force of his moral lesson, he deals with crime on a heroic scale, of such extravagant proportions that the reader, instead of trembling at the consequences of misdoing, merely smiles incredulously.

La gran Semiramis presents the familiar story of Semiramis, as narrated by Justin. The action covers some twenty-twa years and describes the triumphant progress of this monster of vice who, through the betrayal of her husband, becomes consort of Ninus, King of Assyria, whom, in due time, she poisons. Her assassination by her son, Ninias, for whom she entertained an incestuous love, was well deserved, but her transformation into a dove, in accordance with the legend, was a better fate than she merited.

La cruel Casandra presents another woman who is an artist in crime. Her fury is directed against a prince and princess of Leon, and also against a lady of the Court, named Fulgencia. In order to encompass their death, Casandra has no scruples in sacrificing her own brother, and finally dies herself as a penalty for her treachery. The experiences of Marcela in La infelice Marcela are based upon the story of Isabella in the thirteenth canto of the Orlando Furioso. Virués, however, was pitiless with his characters, and refused to allow them to survive the last act. When she is about to be rewarded for 
all her sufferings, she drinks poison by mistake and dies a horrible death. The play lacks interest because the heroine is insignificant. ${ }^{1}$

Delirium reaches its limit in Atila furioso, the protagonist of which is not the infamous Hun, but Flaminia, a woman dressed as a page, whose identity is known only to Atila. The play is made up of scenes of crime and bloodshed, culminating in the attempt of Atila to murder all the guests at a weddingbanquet, the death of Flaminia and Atila's suicide.

In these four tragedies, each act presents a fairly complete action, a method of procedure to which he approvingly refers in the prologue to La gran Semiramis. He applied to his plays the same principles of composition that he later used in his epic poem, El Monserrate, and it would not be unfair to consider them as tragedies in three cantos. His intense imagination and his ignorance of the meaning of moderation, either in fancy or in language, led to a complete disregard of the principle of unity of action. According to his conception, playwriting consisted in the accumulation of horrible incidents.

Two plays by Gabriel Lobo Laso de la Vega, first printed at Alcalá in 1587 , might have been written by Virués in a gentle mood. Composed in three acts with a bewildering variety of metrical forms, they represent a completely unsuccessful attempt to adapt epic material with lyrical incidents, to dramatic form. The Tragedia de la honra de Dido restaurada proposes to correct the false opinion concerning Dido, derived from Vergil, and following Justin's account, describes the murder of Sychæus by Pygmalion, Dido's flight across the seas and arrival at Carthage, and her suicide to escape the unwelcome attentions of the neighboring king, Iarbas. The author apparently conceived of drama as a series of disconnected lyrical scenes. The same faults are found, to an even greater dgree, in the Tragedia de la destruccion de Constantinopla, which deals with the capture of Constantinople by Mohammed II in 1453.

'Mérimée, L'Art dramatique à Valencia, p. 349. 
A reference by Lope de Vega in his Laurel de Apolo to Miguel Sánchez as " the first master that the Muses of Terence have had in Spain", has been interpreted as recognition by Lope that Sánchez had preceded him in writing plays. ${ }^{I}$ On another occasion, in his Arte nuevo de hacer comedias ( 1609 ), Lope states that Sánchez was accustomed to employ in all his comedias the device of speeches with double meaning in order to mislead the auditors and conceal the dénouement until the very end. Inasmuch as Lope de Rueda and Virués are the only other Spanish playwrights mentioned in his treatise, and since Lope used the past tense in speaking of Sánchez's practice, there are grounds for accepting the opinion that the latter was a precursor of Lope.

At the same time, the evidence in this question is conflicting. While we have a sonnet from his pen, dated as early as 1587 , his only two extant plays, La'guarda cuidadosa and La isla barbara, were first published, so far as we know, in 16I5 and 1638 , respectively. A manuscript of the latter play contains licenses for performances, dated I6II and I6I4. Neither of these exhibits the peculiarity of "deceiving with the truth", and we must assume that Lope had in mind other, and probably, earlier plays. When we turn to other references to Miguel Sánchez, we find that he is mentioned after Lope de Vega in Rojas Villandrando's Loa de la comedia, in Cervantes' prologue to his Ocho comedias, and in Suárez de Figueroa's Plaza universal. Such allusions are insufficient foundations upon which to base the chronological relationship of a poet to his contemporaries, but at the same time, Lope's statement that Sánchez was "the first master that the Muses of Terence had", is susceptible of several interpretations. It may be a meaningless compliment, or may express Lope's opinion of the excellence of Sánchez in somewhat elevated comedy, and was not intended to ascribe to him the position of a pioneer. At all events, whether Sánchez was a predecessor or contem-

${ }^{1}$ This was first suggested by Baist in the Deutsche Litteraturzeitung, Januiry, 1892 . 
porary of Lope de Vega, his two extant plays have no kinship with the dramatic compositions written before the comedias of Lope de Vega began to appear on the stage, and therefore are not included in this study. In fact, they show so many characteristics of Lope's manner, that if we accept Sánchez as a precursor of Lope, we should be obliged to ascribe to the former the invention of the comedia nueva, and for this, we have insufficient evidence.

It cannot be denied that Lope de Vega received an important heritage from his predecessors. During his youth, the variety of metrical forms adapted to given situations and expressing different emotions, prevailed in both comedy and tragedy, and the three-act play, had already made its appearance, although at the beginning of his career, he followed the older division of four acts. If we choose to go into details, we may say that he was anticipated by others in the comedy of manners, the comedy of intrigue, the comedia de capa y espada, in plays on ancient and modern history, in the use of Spanish legends and local traditions, in pastoral and mythological plays, and in religious autos. The duplication of scenes between the galán and dama by the lackey and moza is found in certain plays of Torres Naharro, and the gracioso may be regarded as a fusion of the older simple and criado. Lope de Vega perfected the technique, characters and situations transmitted to him by his elders, but he did far more than that. In the words of Mr. Fitzmaurice-Kelley," "He put an end to the simple classification of plays as tragedies and farces: he conceived the comedia which fused the most diverse elements into one spacious whole, and by this invention he was enabled to represent his age, to enthrall his public, and to develop his own amazing powers. He wrought to such purpose that the path which he cut out for himself, and by himself, became the main road. He pictured contemporary modes and humours with unflagging vivacity and unshrinking truth. He opened up the treasures of historic legend, transforming indistinct

${ }^{1}$ Lope de Vega and the Spanish Drama, Glasgow, 1902. 
types and hard automata into living beings, all touched with something of his own urbanity". We need no historical background in order to find delight in the masterpieces of the comedia nueva, but a knowledge of the beginnings of the Spanish drama aids us to appreciate properly the genius of Lope and the glories which he and his successors brought to Spain in the seventeenth century. 


\section{APPENDIX}

\section{BIBLIOGRAPHY}

\section{Chapter I}

The best account of the religious drama before Encina is given by Adolfo Federico, Conde de Schack, Historia de la literatura y del arte dramático en España, vol. i, Madrid, 1885. Also useful in this connection is the introduction of Eugen Kohler to his Sieben spanische dramatische Eklogen, Dresden, I9II. Among the older works may be mentioned the seventh volume of Amador de los Ríos, Historia critica de la literatura española, Madrid, 1865 , and Manuel Cañete, Teatro español del siglo $X V I$, Madrid, 1885. Emilio Cotarelo y Mori sketches the origins of the drama in his study of Encina, published in Estudios de historia literaria de España, Madrid, I901. The Origenes del teatro catalán, Barcelona, I895, of Manuel Milá y Fontanals, and Henri Mérimée's L'Art dramatique a Valencia, Toulouse, I9I3, offer a wealth of material for the study of the origins of the drama in Catalan and Valencian territory. A. Bonilla y San Martin's well-documented monograph, Las Bacantes, o del origen del teatro is especially important for the earlier period. Among the studies treating the early development of the drama in various cities may be mentioned José Sánchez-Arjona's Noticias referentes a los anales del teatro en Sevilla, Sevilla, 1898 , and the same author's El teatro en Sevilla en los siglos XVI y XVII, Madrid, I887; Narciso Diaz de Escovar, Anales del teatro español anteriores al año 1550, Madrid, I910; Julio Milego, El teatro en Toledo durante los siglos XVI y XVII, Valencia, I909, and Ricardo del Arco, Misterios, autos sacramentales $y$ otras fiestas en la Catedral de Huesca, Revista de Archivos, vol. xxiv, I9zo.

The $A$ uto de los Reyes Magos may be read conveniently in J. D. M. Ford's Old Spanish Readings, Ginn and Co., Boston, Ig06, the text of which follows the edition of $\mathbb{R}$. Menéndez Pidal, published in the Revista de Archivos, vol. iv, I900. In the notes to his edition, Professor Ford gives an excellent summary of the previous editions and of the many critical articles regarding this text. I agree with him in seeing little relationship between the Spanish play and the Orléans liturgical text. Aurelio M. Espinosa makes certain emendations of the text of Menéndez Pidal in his edition published in the Romanic Review, vol. vi, 1915, and also 
makes important suggestions concerning the versification. The Auto de los Reyes Magos is also well treated by Fitzmaurice-Kelly, Historia de la literatura española, Madrid, I92I, pp. 8-10, and the bibliography there given is very useful. For Menéndez Pidal's discussion of the date, see Cantar de mio Cid, vol. i, Madrid, I908, pp. $25 \mathrm{ff}$ and I44n.

Menéndez Pidal proves, in my opinion, in his brilliant essay entitled La primitiva poesía lirica española, included in his Estudios literarios, Madrid, Ig20, that the thirteen couplets with the refrain Eya velar found in Gonzalo de Berceo's El duelo que fizo la Virgen Maria, are derived from popular sentinels' songs, and have nothing to do with Easter plays, as has usually been accepted.

Gómez Manrique's Representacion del nacimiento de nuestro Señor, and his two masquerades, may be read in the Cancionero de Gómez Manrique, published by $\mathrm{Paz}$ y Melia, Madrid, 1885, and in R. FoulchéDelbosc's Cancionero castellano del siglo XV, vol. i, Madrid, 19I2, which also contains the Vita Christi of Fr. Iñigo de Mendoza. Menéndez y Pelayo studied the poetry of Gómez Manrique, and also the Vita Christi, in his Antologia de poetas líricos, vol. vi.

Rodrigo Cota's Dialogo entre el Amor y un viejo may be read in the Cancionero de Hcrnando del Castillo, vol. i, Madrid, I882, in Menéndez y Pelayo's Antología de poetas líricos, vol. iv, pp. i-2o, and in FoulchéDelbosc's Cancionero del siglo $X V$, vol. ii. Another version, that seems to be of a later date, was published by Miola, Miscellanea di filologia $e$ linguistica in memoria di Caix e Canello, Florence, 1886. It is discussed by Menéndez y Pelayo, Antología, vol. vi, pp. ccclxxvi-ccclxxxiv.

\section{ChaPter II}

The plays of Juan del Encina were reprinted in the Teatro completo de Juan del Encina, Madrid, 1893, with an introduction by Manuel Cañete and Francisco Asenjo Barbieri. His plays, with the exception of the Representacion del Amor, the Egloga de las grandes lluvias and a part of the Egloga de Placida $y$ Vitoriano, were published with an introduction by Eugen Kohler under the title Representaciones de Juan del Encina, Biblioteca Romanica, Strasbourg, 1914. The Egloga interlocutoria was published by Urban Cronan in the Revue Hispanique, vol. xxxvi, I9I6, and on this play R. E. House published in the Romanic Review, vol. vii, I9I6, an article entitled $A$ Study of Encina and the Egloga interlocutoria. The Auto del repelon was edited with a long critical study, glossary and notes by Alfredo Alvarez de la Villa, Paris, n. d.

For the biography of Encina and a critical study of his plays, see Emilio Cotarelo y Mori, Estudios de historia literaria, Madrid, Igor, pp. 103-8:; Menéndez y Pelayo, Antología de poetas líricos, vol. vii, pp. i-c; Eugen Kohler, Sieben spanische dramatische Eklogen, Dresden, I9II; 
E. Díaz Jiménez y Molleda, Juan del Encina en León, Madrid, I909; R. Mitjana, Estudios sobre algunos músicos españoles, Madrid, 1918 and J. P. W. Crawford, The Spanish Pastoral Drama, Philadelphia, I915. Very interesting documents regarding Encina's family and his relations with Lucas Fernández were published by Ricardo Espinosa Maeso in an article entitled Nuevos datos biográficos de Juan del Encina in the Boletín de la Real Academia Española, vol. ix, I921.

\section{Chapter III}

The plays of Lucas Fernández were reprinted at Madrid in I867 with an introduction by Manuel Cañete, which is also included in the same critic's Teatro español del siglo XVI, Madrid, 1885. Gil Vicente's plays have recently been edited by J. Mendes dos Remedios, 3 vols., Coimbra, I907-I9I4. For critical studies on Gil Vicente, see the bibliography in Fitzmaurice-Kelly's Historia de la litcratura española, Madrid, I92I, and Aubrey F. G. Bell, Gil Vicente, Oxford University Press, I92I. Torres Naharro's Dialogo del nascimiento is included in Menéndez y Pelayo's edition of the Propalladia de Bartolomé de Torres Naharro, vol. ii, Madrid, Igoo.

The Egloga en loor de la natividad by López de Yanguas and the Farsa nuevamente trobada of Fernando Díaz may be read in Kohler's Sieben spanische dramatische Eklogen, Dresden, I9I I, which also contains critical studies of these dramatists. The latter play is also included in Urban Cronan's Teatro español del sigl. XVI, Madrid, I9I3. Extracts from the Christmas play of López Ranjel are given by Pedro Salvá y Mallén, Catálogo de la biblioteca de Salvá, vol. i, Valencia, 1872, no. I298.

The plays of Sánchez de Badajoz were reprinted by Barrantes in two volumes of the Libros de Antaño, Madrid, I882-86, and the first volume was republished by J. López Prudencio at Badajoz in I9Io. For a good critical study of Sánchez de Badajoz, see J. López Prudencio, Diego Sánchez de Badajoz, estudio crítico, biográfico y bibliográfico, Madrid, I9I5.

Extracts from Altamira's Easter play are given in Moratín's Orígenes del teatro español. The Farsa del mundo y moral of López de Yanguas was reprinted by Léo Rouanet in his Colección de autos, farsas $y$ coloquios del siglo XVI, vol. iv, Madrid, IgOI and by Cronan, Teatro español del siglo XVI. The same author's Corpus play was described by Cotarelo y Mori, Revista de Archivos, vol. vii, 1902, pp. 253-56. The anonymous Farsa sacramental was reprinted by M. Serrano y Sanz, Revista de Archivos, vol. x, 1904.

The Tragedia Josefina of Carvajal was reprinted at Madrid in 1870 from an edition of 1546 by Cañete, who devotes to him a chapter in his Teatro español del siglo XVI. A. Morel-Fatio, Romania, vol. xv, I886, 
pp. $462-68$, describes an edition of this play of 1540 and corrects a number of statements made by Cañete.

The plays of Sebastián de Horozco are included in the Cancionero de Sebastián de Horozco, Seville, I874, and have been studied in Cotarelo y Mori's monograph entitled El licenciado Sebastián de Horozco y sus obras, Madrid, I9I6.

The Tragicomedia del Parayso y del Infierno was reprinted by Cronan, Teatro español del siglo XVI. Extracts from the anonymous Coplas de la Muerte are found in Salvá's Catálogo, already mentioned, vol. i, no. I 195 .

\section{Chapter IV}

The Comedia Trofea of Torres Naharro was reprinted by Cañete and Menéndez y Pelayo in the Propalladia de Bartolomé de Torres Naharro, vol. i, Madrid, I880, and is discussed by Menéndez y Pelayo in the second volume of the same, Madrid, Igoo. On the mission of Tristão da Cunha, see the essay of Achille Pellizzari entitled Strenne di Leone Decimo, published in his Portogallo e Italia nel secolo XVI, Naples, IgI4.

The Egloga Real of the Bachiller de la Pradilla was reprinted and discussed by Kohler in his Sieben spanische dramatische Eklogen. The Farsa sobre la felice nueva de la concordia e paz of Hernán López de Yanguas was also studied by Kohler, and was reprinted by Urban Cronan, Teatro español del siglo XVI, Madrid, I9I3. The masquerade of Luis Milán is included in his El cortesano, reprinted in the Colección de libros españoles raros y curiosos, vol. vii, Madrid, I874. It is well discussed in Henri Mérimée's L'Art dramatique à Valencia, Toulouse, I9I3.

Gil Vicente may be real conveniently in the edition of J. Mendes dos Remedios, 3 vols., Coimbra, 1907-I9I4. For studies of his dramatic activity, see the bibliography in Fitzmaurice-Kelly's Historia de la literatura española, Madrid, I92I, Aubrey F. G. Bell, Gil Vicente, Oxford University Press, 192I, and Aubrey F. G. Bell, Portuguese Literature, Oxford, I922.

The pastoral plays of the sixteenth century were studied by J. P. W. Crawford, The Spanish Pastoral Drama, Philadelphia, 1915, and most of the early pastoral plays included in this chapter were discussed by Kohler, Sieben spanische dranatische Eklogen. The plays of Fernández were published by Manuel Cañete, Farsas y églogas al modo y estilo pastoril y castellano fechas por Lucas Fernández, Madrid, 1867. The Egloga de Torino was republished by Menéndez y Pelayo in vol. ii of his Orígenes de la novela, Madrid, 1907. The anonymous Egloga pastoril was reprinted by Kohler and by Cronan, and was also discussed by Mérimée, L'Art dramatique à Valencia. Kohler and Cronan both included the Egloga nueva of Diego Durán in their important collections 
of sixteenth-century plays, and the same is true of the Egloga of Juan de Paris, of which Cronan reprinted the edition of 1536 and Kohler that of $155 \mathrm{I}$.

Diego de Negueruela's Farsa Ardamisa was reprinted by Léo Rouanet in the Bibliotheca hispanica, Madrid, I900, and the Farsa Comelia was republished by Cristóbal Pérez Pastor in La imprenta en Medina del Campo, Madrid, 1895. The Coplas de una doncella y un pastor may be read in Gallardo's reprint of an edition of 1604 in the Ensayo de una biblioteca de libros raros y curiosos, vol. i, Madrid, 1863, cols. 703-7II. An edition of about 1530 is mentioned in the Catálogo de Salvá, vol. i, p. 420 .

Sánchez de Badajoz's Farsa de la hechicera is reprinted in the Recopilación en metro, Libros de antaño, vol. xi, Madrid, 1882, and the play is discussed in López Prudencio's critical study of that author published at Madrid in 1915. The Comedia Florisea (1553) of Avendaño was republished by Adolfo Bonilla y San Martin in the Revue Hispanique, vol. xxvii, 1912 and L. Pfandl described the edition of $155 \mathrm{I}$ in the Zeitschrift für rom. Phil., vol. xxxix, 1919. Bonilla y San Martín republished the Comedia Tibalda, together with the additions of Hurtado de Toledo in the Bibliotheca hispanica, Madrid, I903.

The Comedia llamada discordia y question de amor was reprinted from an edition of $\mathrm{I} 6 \mathrm{I} 7$ by Francisco $\mathrm{R}$. de Uhagón in the Revista de Archivos, vol. vi, 1902. Lope de Rueda's Coloquio llamado prendas de amor may be read in the second volume of the Spanish Academy edition of the Obras de Lope de Rueda, Madrid, 1908. Gallardo reprinted the 1588 edition of the Comedia Fenisa in El Criticón, Madrid, 1859, and Bonilla y San Martin republished an edition of 1625 in the Revue Hispanique, vol. xxvii, 1913. The Comedia Metamorfosea may be read in Ochoa's Tesoro del teatro español, vol. i, 1838 , in which the original division in four acts has been reduced to three. On this and other works of Romero de Cepeda, see Gallardo, Ensayo, vol. iv, cols. 254-59.

\section{Chapter V}

The plays of Torres Naharro were reprinted by Cañete and Menéndez y Pelayo in the Propalladia, Madrid, I880-1900, Libros de antaño, vols. ix-x, and Menéndez y Pelayo's important introduction is included in the second volume. A scholarly review of this edition and introduction by A. L. Stiefel appeared in the Literaturblat für germanische und romanische Philologie, vol. xxiv, 1903, pp. I 19-126. J. E. Gillet's article entitled Une Edition inconnue de la Propalladia de Bartolomé de Torres Naharro, published in the Romanic Review, vol. xi, 1920, is of considerable bibliographical interest. Menéndez y Pelayo studied the relationship between the Comedia Himenea and the Celestina in his 
Origenes de la novela, vol. iii, and this question has been treated more definitely by M. Romera-Navarro in his Estudio de la Comedia Himenea de Torres Naharro, published in the Romanic Review, vol. xii, Ig2I. On possible sources of the Comedia Calamita, see J. P. W. Crawford, $A$ Note on the Comedia Calamita of Torres Naharro, Modern Language Notes, vol. xxxvi, I921.

The Comedia Tesorina and Comedia Vidriana of Jaime de Güete were reprinted by Cronan in his Teatro español del siglo XVI. These plays and the other imitations of the Celestina and Comedia Himenea mentioned in this chapter were discussed briefly by Menéndez y Pelayo in his Origenes de la novela, vol. iii. The Comedia Radiana was edited by $\mathrm{R}$. E. House in Modern Philology, vol. vii, I910. The Comedia Tidea of Francisco de las Natas was reprinted by Cronan in Teatro español del siglo $X V I$ and is the subject of an article by M. Romera-Navarro entitled Observaciones sobre la Comedia Tidea, published in Modern Philology, vol. xix, I921. The Auto de Clorindo was reprinted with a brief introduction by Bonilla y San Martin in the Revue Hispanique, vol. xxvii, 19I2.

Diego de Avila's Egloga interlocutoria was edited by Kohler in Sieben spanische dramatische Eklogen. For the Farsa de Costanza, see R. Foulché-Delbosc, Revue Hispanique, vol. xxxvi, I9I6, pp. 489-508, and Cañete, Teatro español del siglo XVI, Madrid, 1885. The Farsa del matrimonio of Diego Sánchez de Badajoz is included in the second volume of the Recopilación en metro, published at Madrid in 1886 by Barrantes. The play was also reprinted by Gallardo, Ensayo, vol. i, cols. 929-46 from a suelta edition of 1603 , which he erroneously believed to be of I530.

For Gil Vicente, see bibliographical note to Chapter III. The Farsa Salamantina was edited by A. Morel-Fatio in the Bulletin Hispanique, vol. ii, 1900 with an important introduction, and additional facts concerning Palau's plays are found in the preface to Léo Rouanet's edition of Palau's Farsa llamada custodia del hombre, published in the Archivo de Investigaciones históricas, vol. i. 'R. E'. House pointed out certain resemblances between the Farsa Salamantina and the Comedia Tesorina in an article entitled The Sources of Bartolomé Palau's Farsa Salamantina, published in the Romanic Revierv, vol. iv, 19I3.

The anonymous Farça a manera de tragedia was reprinted by Hugo A. Rennert in the Revue Hispanique, vol. $x x v$, I9II, and in a revised edition at Valladolid in 19I4. The Comedia Prodiga was republished by M. de Alava at Seville, I868, and was discussed by Menéndez y Pelayo in the third volume of his Origenes de la novela. The oftrepeated error that the Comedia Prodiga is adapted from a play by Cecchi was first corrected by A. L. Stiefel, Literaturblatt für germanische und romanische Philologie, vol. xxiv, 1903, p. I25. 


\section{Chapter VI}

The best edition of the plays of Lope de Rueda is that of E. Cotarelo y Mori, 2 vols., Madrid, 1908, which contains an important introduction. The monograph of $\mathrm{N}$. Alonso Cortés, entitled Un pleito de Lope de Rueda, Madrid-Valladolid, I903, contains valuable biographical material. The sources of Medora and Armelina were first indicated by A. L. Stiefel in an article entitled Lope de Rueda und das italienische Lustspiel, Zeitschrift für romanische Philologie, vol. xv, $189 \mathrm{I}$.

The comedia of Sepúlveda was printed by Cotarelo y Mori in the Revista española de Literatura, Historia y Arte, vol. i, Madrid, I9oI. Its source is discussed by J. P. W. Crawford in an article entitled Notes on the Sixteenth Century 'Comedia de Sepúlveda', published in the Romanic Review, vol. xi, I920.

The three comedies of Timoneda, and the volume entitled Turiana, were reprinted by Menéndez y Pelayo in the Obras completas de Juan de Timoneda, vol. i, Valencia, IgII. Menéndez y Pelayo's death prevented the publication of the second volume, with the promised introduction. The best account of Timoneda and of the plays included in Turiana is found in Henri Mérimée's L'Art dramatique à Valencia, Toulouse, 1913. The sources of the prologues of the Comedia de Amphitrion and Comedia de los Menemnos, and the indebtedness of Timoneda to López de Villalobos, were discussed by J. P. W. Crawford in the Modern Language Review, vol. ix, 19I4, pp. 248-5I. The source of the Farça Trapacera was mentioned in the indispensable Geschichte des neueren Dramas by Creizenach, who at that time knew the play only from the brief summary given by Moratin.

The three plays of Alonso de la Vega were reprinted by Menéndez y Pelayo, apparently without the formality of proof correction, in the publications of the Gesellschaft fïr romanische Literatur, Dresden, 1905. This edition contains an excellent introduction by the editor. The Farsa Rosiela was republished by Cronan in his Teatro español del siglo XVI. Navarro's Comedia de la marquesa de Saluzia was reprinted by Miss Caroline R. Bourland in the Revuc Hispanique, vol. ix, 1902, and is also discussed in the same writer's monograph Boccaccio and the Decameron in Castilian and Catalan Literature, Revue Hispanique, vol. xii, I905.

For the Latin comedies of Juan Pérez, and the Ate relegata et Minerva restituta, see the interesting article by $\mathrm{A}$. Morel-Fatio in the Bulletin Hispanique, vol. v, I903, pp. 9-24. For my knowledge of the plays of Lorenzo Palmyreno I am entirely indebted to $H$. Mérimée's oft-mentioned L'Art dramatique à Valencia.

The best account of the development of the entremés is found in E. Cotarelo y Mori's Colección de entremeses, loas, bailes, jácaras $y$ mojigangas, tomo i, vol. i, Madrid, 19II. See also the introduction by 
Léo Rouanet, Intermèdes espagñols du XVII' siècle, Paris 1897 and by G. T. Northup to his edition of Ten Spanish Farces, D. C. Heath and Co., Boston, I922. For the beginnings of this type, see an article by W. Shaffer Jack entitled Development of the "entremés" before Lope de Rueda, printed in the Publications of the Modern Language Association of America, vol. xxxvii, Igz2.

The pasos of Lope de Rueda, Gil Vicente, Sánchez de Badajoz and other authors are included in editions already mentioned. The Entremes del mundo y no nadie was published by Foulché-Delbosc in the Revue Hispanique, vol. vii, Igoo. On this theme, see J. Bolte's article Niemand und Jemand, in the Jahrbuch der deutschen Shakespeare-Gesellschaft, vol. xxix, I894, and references on page 74. The Entremes de las esteras may be read in Léo Rouanet's Colección de autos, farsas, y coloquios del siglo XVI, vol. ii, I90I. The last eight entremeses mentioned may be read in 'Cotarelo's Colección de entremeses, etc., mentioned above. The source of the Entremes de un vicjo que es casado con una mujer moza was mentioned by G. L. Lincoln in the introduction to his. edition published in the Revue Hispanique, vol. xxii, I9Io.

\section{Chapter VII}

Montemayor's Christmas play is found in Las obras de George de Montemayor, published at Antwerp in 1554 by Juan Steelsio. There is a copy of this book in the library of the Hispanic Society of America, and there is another copy in the library of Professor H. A. Rennert. The Danza del santisimo nacimiento of Suárez de Robles was described by Moratín in Orígenes del teatro español. El pecador of Bartolomé Aparicio was reprinted in Gallardo's Ensayo, vol. i, cols. 22I-245. The anonymous Comedia a lo pastoril was edited with an introductory study by J. P. W. Crawford in the Revue Hispanique, vol. xxiv, I9II. The Farsa del sordo was reprinted in Gallardo's Ensayo, vol. i, cols. 1146-64, and may also be read in vol. ii of the Obras de Lope de Rueda, edited by Cotarelo y Mori, Madrid, 1908.

The anonymous Auto de la quinta angustia was republished by J. P. W. Crawford in the Romanic Review, vol. iii, 1912. The Auto llamado Lucero de nuestra salvacion may be read in vol. $\mathrm{xxxv}$ of the Biblioteca de Autores españoles, no. glo, where it is ascribed erroneously to Inocencio de Salceda. Three auctos of Palau's Victoria de Cristo were reprinted in the appendices to Rouanet's Colección de autos, farsas $y$ coloquios del siglo XVI, vol. iv, Madrid, I90I. The best study of Palau's dramatic work is found in Rouanet's edition of the same author's Farsa llamada custodia del hombre, published in the Archivo de Investigaciones históricas, vol. i, I9I I.

The oft-mentioned codex of ninety-six plays preserved at the National 
Library of Madrid was published with important notes by Léo Rouanet, Colección de autos, farsas y coloquios del siglo XVI, 4 vols., Madrid, 1901. On the comic elements in these plays, see J. P. W. Crawford, The Pastor and Bobo in the Spanish Religious Drama of the Sixteenth Century, Romanic Review, vol. i, I9II, and The Devil as a Dramatic Figure in the Spanish Religious Drama before Lope de Vega, Romanic Review, vol. i. A chapter in Cañete's Teatro español del siglo XVi discusses the plays of Alonso de Torres and Francisco de las Cuebas on the martyrdom of San Justo and San Pastor, and the Representacion of Cuebas was edited by J. P. W. Crawford in the Revue Hispanique, vol. xix, 1908. The dramatic work of Jaime Ferruz is discussed in Cañete's Teatro español del siglo XVI.

The religious plays of Timoneda are studied in H. Mérimée's L'Art dramatique à Valencia, Toulouse, I913, and may be read in vol. lviii of the Biblioteca de Autores españoles. Pedraza's Danza de la Mucrte was reprinted in the same volume, and the Comedia de Sancta Susaña may be read in Gallardo's Ensayo, or in the edition of A. Bonilla y San Martin, Revue Hispanique, vol. xxvii, 1912. The Auto de las cortes de la Muerte was republished in vol. xxxv of the Biblioteca de Autores españoles. Reference has already been made to Rouanet's edition of the Custodia del hombre of Palau. The latter's Historia de Santa Orosia was published at Madrid in I 883 by Aureliano Fernández-Guerra with the title Caida y ruina del imperio visigótico español. Primer drama que las representó en muestro teatro.

A brief account of the Jesuit plays is found in the notes to Ticknor's Historia de la literatura española, vol. ii, Madrid, I851, pp. 543-59. Two of these plays, namely, Parabola Coenae and Examen Sacrum, as well as a number of the compositions later published by Rouanet, and an important study on the auto sacramental by E. González Pedroso, are included in vol. lviii of the Biblioteca de Autores españoles.

\section{Chapter VIII}

The Farsa de la castidad de Lucrecia was reprinted by A. Bonilla y San Martin in the Reoue Hispanique, vol. xxvii, 1912. There is a reference to the Tragedia de los amores de Eneas in Gallardo's Ensayo, vol. iv, col. 1460 .

Pedro Henríquez Ureña discusses Pérez de Oliva's versions of Greek tragedies in his interesting monograph, El maestro Hernán Pérez de Oliva, La Habana, I9I4. These translations may be read in the Obras del maestro Fernán Pérez de Oliva, Madrid, 1787 , or in vol. vi of López de Sedano's Parnaso español. A fac-simile of the 1528 edition of La venganza de Agamemnon was published by Bonilla y San Martín, Obras dramáticas del siglo XVI, primera serie, Madrid, I9I4. 
Nise lastimosa and Nise laureada were reprinted in vol. vi of López de Sedano's Parnaso español, and also in the first volume of E. de Ochoa's Tesoro del teatro español, Paris, 1838 . Their relationship with Seneca was studied by J. P. W. Crawford in an article entitled The Influence of Seneca's Tragedies on Ferreira's Castro and Bermudez's Nise lastimosa and Nise laureada, Modern Philology, vol. xii, rgi4.

The fourteen plays of Juan de la Cueva may be read in the two volume edition of his Comedias $y$ tragedias, published in 1917 by the Sociedad de Bibliófilos españoles, with an introduction by Francisco A. de Icaza, which adds considerably to our knowledge of the poet's life and corrects many previous misstatements. The relationship of the Comedia del degollado to Measure for Measure is discussed by J. P. W. Crawford, A Sixteenth-Century Spanish Analogue of Measure for Measure, Modern Language Notes, vol. xxxv, I9zo. On the Comedia del Infamador, see the article by Joseph E. Gillet, Cueva's Comedia del Infamador and the Don Juan Legend, published in Modern Lang. Notes, vol. xxxvii, I922. Los amantes was reprinted in a limited edition at Valencia in 1908 by $F$. Carreres y Valle, with an introductory study by F. Martí Grajales, and it is also discussed by Mérimée in his L'Art dramatique d Valencia.

López de Castro's Marco Antonio y Cleopatra was edited by H. A. Rennert in the Revue Hispanique, vol. xix, I908. Los cautivos was printed by A. Paz y Melia in the Revista de Archivos, vol. xxi, rgog. The Comedia salvaje was reprinted by Eugenio de Ochoa, Tesoro del teatro español, vol. i, Paris, 1838 , and also in the Archivo Extremeño of Badajoz. Its relationship with the Celestina was discussed by Menéndez y Pelayo in his Origenes de la novela, vol. iii, pp. cclxviiicclxx. The Tragedia de Narciso was edited with an introductory study by J. P. W. Crawford, Philadelphia, 1909. A number of extracts from the Gran comedia de los famosos hechos de Mudarra, as well as a critical study of the play, are found in R. Menéndez Pidal's well-known book, La leyenda de los Infantes de Lara, Madrid, I8g6.

Isabela and Alejandra may be read in the Obras sueltas de Lupercio $y$ Bartolomé Leonardo de Argensola, Madrid, 1889, and also in E. de Ochoa's Tesoro del teatro español, vol. i, and in López de Sedano's Parnaso español, vol. vi. These plays were discussed by J. P. W. Crawford in Notes on the Tragedies of Lupercio Leonardo de Argensola, Romanic Review, vol. v, I9I4.

Los tratos de Argel and La Numancia may be read conveniently in the Teatro completo de Miguel de Cervantes Saavedra, vol. i, Madrid, I 896 . A critical study of the plays of Cervantes by A. Cotarelo y Valledor was published at Madrid in I9I5. See also Rudolph Schevill's Cervantes, New York, IgIg. 
I received too late for use in my discussion of the plays of Cervantes the fifth and sixth volumes of the Obras completas de Miguel de Cervantes Saavedra, Comedias $y$ entremeses, by Professor Schevill and Don Adolfo Bonilla $\mathrm{y}$ San Martín, published at Madrid in 1922. Volume five reprints from manuscripts El trato de Argel and El cerco de Numancia, and volume six contains an important study of Cervantes' plays. The editors show that there is good reason to believe that some of the plays written shortly after Cervantes' return from Algiers were utilized, at least in part, in the composition of the comedias published in 1615 .

With the exception of La gran Semiramis, reprinted at Leipzig in 1858 , the tragedies of Virués must be read in the original edition. These plays were carefully studied by Henri Mérimée in L'Art dramatique d Valencia. The two tragedies of Lobo Lasso de la Vega were published at Madrid in 1587 , and La destruccion de Constantinopla was. also included in a volume entitled Seis comedias de Lope de Vega $y$ de otros autores, published at Lisbon in 1603 .

La isla barbara and La guarda cuidadosa were published by H. A. Rennert, Philadelphia, I 896 , with an important introductory study. A. L. Stiefel argues against the priority of Sánchez to Lope de Vega in the Literaturblatt für germanische und romanische Philologie, vol. xx, 1899, p. 98.

The indebtedness of Lope de Vega to his predecessors has been discussed by Schack, Historia de la literatura y del arte dramatico en: España, vol. ii, pp. 84-9I ; H. A. Rennert, The Life of Lope de Vega, Glasgow, 1904, pp. 378-388; H. A. Rennert and Américo Castro, Vida de Lope de Vega, Madrid, I919, pp. 369-377; James Fitzmaurice-Kelly, Lope de Vega and the Spanish Drama, Glasgow, 1902; H. Mérimée, L'Art dramatique d̀ Valencia, pp. 4I3-422, and Rudolph Schevill, The. Dramatic Art of Lope de Vega, together with La dama boba, Berkeley,. 1918. 



\section{INDEX}

Abrahan (Aucto de), 146 Acusacion contra el genero humano (Auto de), I44, 145

Adan (Farsa del sacramento de), I 48

Alione (Giovan Giorgio), 91, 92

Altamira (Pedro), 55, 185

Alvarez de Ayllón (Per), 82-83, 187

Amor divino (Farsa del sacramento del), 147

Amores de Eneas y de la reyna Dido (Tragedia de los), I53, 191

Aparicio (Bartolomé), 139, I90

Ariosto (Lodovico), 100, I16, I22, 123, 125, 128, 178

Assumption de nuestra Señora (Auto de la), I44

Astrologo borracho (Entremés del), 136

Asuncion de nuestra Señora (Aucto de $(a), 144$

Avendaño (Francisco de) , 82, 187

Avila (Diego de), 105-106, 188

Berceo (Gonzalo de), 184

Bermúdez (Jerónimo), 154-I57, 192

Bodas de España (Farsa sacramental de las), 148

Boscán (Juan), 154

Calderón de la Barca (Pedro), 38, 168

Carvajal (Micael de), 60-6I, I50, 185-186

Castillejo (Cristóbal de), 106, I 88

Celestina $(L a), 36,97$, 101, 102, 103, 168

Cervantes Saavedra (Miguel de), III, I60, I70, I73-176, I92-193

Cinco sentidos (Farsa del sacramento de los), 148

Circuncision de nuestro Señor (Auto de la), 143

Clorindo (Auto de), I04-105, I88

Comedia a lo pastoril, I39-140, 142, 190
Conversion de la Madalena ( $A$ uto de $(a), \mathrm{I} 43$

Conversion de Sant Pablo (Aucto de $l a), 145$

Cornelia (Farsa llamada), 81

Cortes de la yglesia (Farsa del sacramento de las), I 47

Cota de Maguaque (Rodrigo), I\&I9, 26, 34, 184

Cuebas (Francisco de las), 145, I9I

Cueva (Juan de la), 90, 158-164 192

Cueva y Silva (Francisco de ia), I69, 192

Culpa y la captividad (Aucto de la), 142, 143

Degollacion de Sant Juan Baptista ( Aucto de la), I43

Desafio del hanbre (Farsa saeramental llamada), I47

Descendimiento de la cruz (Aucto del) $, 143,144$

Despedimiento de Christo (Auto del), 143, I44

Desposorios de Isac (Auto de los), 146

Desposorios de Joseph (Auto de los), 146

Desposorios de Moysen (Auto de los), 146

Destierro de Agar (Auto del), 146

Destruicion de Jerusalen (Auto de $(a), 143,144$

Díaz (Fernando), 49, 185

Díaz Tanco de Frexenal (Vasco), 55-56

Dolce (Lodovico), 172

Donas (Aucto de las), 148

Doncella y un pastor (Coplas de una), 8I, I87

Dovizi da Bibbiena (Bernardo), 99-100, II 3

Durán (Diego), 78-79, 186

Egloga pastoril, 78, 186 
Emperador Juveniano (Aucto del), I 48

Encina (Juan del), 20-38, 39, 48, $49,74,78,82,83,100,103,104$, I29, I 38, I $84-185$

Engaño (Farsa del sacramento del), I 48

Entendimiento niño (Farsa del sacramento del), 148

Entrada de Cristo en Jerusalem (Auto de la), 143

Entrada del vino (Farsa del sacramento de la), 147

Esposa de los cantares (Farsa del sacramento de la), I 48

Esteras (Entremés de las), 136, 141

Euripides, I54

Famosos hechos de Mudarra (Gran comedia de los), I69-170, I92

Farça a manera de tragedia, I03I04, 188

Farsa sacramental, 58-59, 185

Fenisa (Coloquio de), 85, I44-I45, 148

Fenisa (Comedia), 84-85, 187

Fernández (Lucas), 21, 27, 34, 38, $39-4 \mathrm{I}, 43,48,49,54-55,74-77$, I 85,186

Ferreira (Antonio), I55-157

Ferruz (Jaime), I4I, I46, I9I

Fide ypsa (Colloquio de), I47-148

Finamiento de Jacob (Aucto del), 146

Fuente de la gracia (Farsa sacramental de la), I47

Fuente de San Juan (Farsa del sacramento de la), 148

Giancarli (Gigio Arthemio), II3

Gl'Ingannati, I I4, 1 I8

Güete (Jaime de), IOI-IO2, I09, I88

Hierros de Adan (Aucto de los), 142

Hijo prodigo (Aucto del), 143

Hijo que negó a su padre (Entremés de un). 136

Horozco (Sebastián de) , 6r-62, 131, 186

Hospedamiento (Auto del), I43

Huida de Egipto (Aucto de la), 143

Hurtado de Toledo (Luis), 83, 150

Izquierdo Zebrero (Ausías), I40, 144
Jonson (Ben), $7 \mathrm{I}$

Justicia divina (Auto de la), I42

Ladrones (Segundo entremés de los), 136

Lazarillo de Tormes, 62, 135

Lebrixa (Fr. Marcelo de), 49

Lenguajes (Farsa del sacramento de los), I48

Leonardo de Argensola (Lupercio), I70-173, I92

Lepra de Naaman (Aucto de la), 146

Lobo Laso de la Vega (Gabriel), 179, 193

López de Castro (Diego), I67, I92

López de Villalobos (Francisco), 120, 121

López de Yanguas (Hernán), 37, $48-49,56,58,68,146,148,185,186$

López Ranjel (Pero), 49, 185

Los cautivos, I67-168

Lucha de Jacob (Aucto de la), I46

Madrid (Francisco de), 65

Magna (Aucto del), I46

Maldonado (Juan), I27

Mal Lara (Juan de), I59

Manrique (Gómez), 12-13, 18, 148, I84

Martínez (Esteban), 49

Martyrio de Sancta Barbara (Auto $d e l)$, I 45

Martyrio de Sancta Eulalia (Aucto $d e l), 145$

Martyrio de Sant Justo y Pastor (Auto del), I45

Mascarón, I45

Melgar (Juan de), 85

Mendoza (Fray Iñigo de), I3-I4, I84

Milogro de Sancto Andres (Aucto de un), 145

Milán (Luis), 68-69, 186

Miranda (Luis de), I10, I 88

Moneda (Farsa sacramental de la), 147

Montemayor (Jorge de), 83, I38, 190

Moselina (Farsa del sacramento de), I47

Muchacho llamado Golondrino (Entremés de un), 136

Muerte (Coplas de la), 64, I86

Mucrte de Adonias (Auto de la), I 46 
Natas (Francisco de las), 103, 188 Naval y Abigail (Auto de), I46

Navarro (Pedro), 126-127, 189

Negueruela (Diego de), 80-81, I87 Ortiz (Agustin), 102-103, 188

Paciencia de Job (Auto de la), 146

Palau (Bartolomé), Io9-IIo, I40I4I, I42, I44, I50-15I, I88, I90, I9I

Palmyreno (Lorenzo), I28-129

Parabosco (Girolamo), 118

Parayso y del infierno (Tragicomedia del), 63, I86

París (Juan de), 79-80, 82, 187

Pastor (Juan), 49, I53-154, I9I

Peccado de Adan (Auto del), 145146

Pedraza (Juan de), 149

Peralforja (Farsa del sacramento de), 147

Pérez (Juan), II4, 128, I89

Pérez de Oliva (Hernán), I2I, I54, I9I

Pero Hernandez (Segundo entremés de), 136

Plautus, 91, II3, I20, 121, I22, I27

Prado (Fernando de), 67-68, 186

Prematica del pan (Farsa del sacramento llamada), 147

Prevaricacion de nuestro padre Adan (Auto de la), 145-146

Prision de Sant Pedro (Aucto de la), 145

Pueblo gentil (Farsa del sacramento del), I48

Quando Abrahan se fue a tierra de Canaan (Auto de), 146

Quando Jacob fue huyendo a las tierras de Aran (Aucto de), I46

Quando Sancta Helena hallo la cruz (Aucto de), I45

Quatro Evangelistas (Farsa del sacramento de los), I47

Quinta angustia (Auto de la), I40, I44, 190

Redencion del genero humano (Auto de la), 143, 144

Residencia del hombre (Auto de la), 147

Residencia del hombre (Farsa sacramental de la), 146-147

Resurrecion de nuestro Señor (Aucto de la), I43, 144
Resurrection de Christo (Auto de la), 143, 144

Rey Asuero (Auto del), I46

Rey de Artieda (Andrés), 164-167, I92

Reyes Magos (Auto de los), 9-10, 183,184

Rey Nabucdonosor (Aucto del), I42

Robo de Digna (Auto del), I46

Romero de Cepeda (Joaquín); 85, I68-169, 187, I92

Rosiela (Farsa), 126, 189

Sacrificio de Jete (Auto del), 146

Sacramento (Farsa del), I47

Sacreficio de Abrahan (Auto del), I 46

Sánchez (Miguel), I80-181, 193

Sánchez de Badajoz (Diego), 49$54,56-57,59-60,64,81-82,106-$ I07, I30, 185, 187, 188

Sanct Christoval (Aucto de), 145

San Francisco (Auto de), I45

Sannazzaro (Jacopo), 66, 7I

Sanson (Auto de), 146

Sant Jorge (Auto de), 145

Sembradores (Farsa del sacramento de los), 147

Seneca, I53

Sepúlveda $(. .$.$) , II7-I I9, I3I, I\&9$

Shakespeare (William), I I4, II5, $163,164,167$

Simón Abril (Pedro), I21, 154

Sophocles, I54

Sordo (Farsa del), I40, 190

Suárez de Robles (Pedro), 138I39, 190

Sueño de Nabucdonosor (Auto del), 142

Tebaldeo (Antonio), 32-33

Terence, 99

Timoneda (Juan de), 5I, I13, II5, 1 19-125, I27, 134, I35-136, 147 , 148-149, 189, 191

Tobias (Auto de), 146

Torino (Egloga de), $77-78,83,186$

Torres (Alonso de), I45, I9I

Torres Naharro (Bartolomé de), $47-48,65-67,82,87-\mathrm{IOI}, \mathrm{IO} 2$, IO3, I04, 124, I29, I48, I86, I87-I88

Tres coronas (Farsa del sacramento de las), 147

Tres estados (Farsa del sacramento de los), 147 
Triunfos de Petrarca (Aucto de los), 148

Triunpho del sacramento (Farsa del), $\mathbf{1} 47$

Ungion de David (Aucto de la), 146

Vázquez (Dionisio), I52

Vega (Alonso de la), 125-126, 189

Vega Carpio (Lope Félix de), 158 , I6I, I68, I80, I8I-182, 193

Verdad y la Mentira (Aucto de la), 147

Vicente (Gil), 38, 4I-47, 48, 58, 63$64,70-74,98$, I02, 107-I09, I30, 185

$V i e j o$ que es casado con una mujer moza (Entremés de un), I36

Virués (Cristóbal de), 176-179, 193

$V$ isitacion de Sant Antonio (Aucto de $l a), 145$

Zamberti (Bartholomeo), 99 


\section{Series in Romanic Languages and Literatures}

1. THE LIFE AND WORKS OF CHRISTOBAL SUAREZ DE FIGUEROA. BY J. P. Wickersham Crawford, Ph.D. 1907. Price \$r.50.

2. WAS FERNANDO DE HERRERA A GREEK SCHOLAR? BY R. M. BEACH, Ph.D. 1908. Price \$1.00.

3. FRATCISCO DE LA CUEVA Y SILVA. TRAJEDIA DE NARCISO. By J. P. Wickersham Crawford, Ph.D. Igog. (Out of print).

4. THE LIFE AND WORKS OF CHRISTOBAL DE CASTILIEJO, THE LABT OF THE Natiofalists IN CASTILIAN POBTRY. By Clara leonora Nrcolay, Ph.D. Igro. Price \$r.50.

5. LA ESPANOLA DE FLORENCIA (O BURLAS VERAS, Y AMOR INVENCIONERO) COMEDIA FAMOSA DE CALDERON DE LA BARCA. By S. L. Mrllard Rosengerg, Ph.D. 19ur. Price \$2.00.

6. THE LITERART RELATIONS BETWEEN LA FONTAINE AND THE "ASTREE" OF hONORE D' URFE. By Walther P. Fischer, Ph.D. Ig13. Price \$1.50.

7. DIALOGE DE LA VIDA DE LOS PAJES DE PALOCIO BY DIEGO DE hERMOSIlla. Edited by Donald Mackenzie, Ph.D. 19i6. Price $\$ 2.00$.

\section{EXTRA SERIES}

x. The spanish pastoral Romances. By Hugo A. Rennert, Ph.D. xgx2. Price $\$ 2.00$.

2. LAS BURLAS VERAS. COMEDIA FAMOSA DE LOPE DE VEGA CARPIO. By S. L. Mrllard Rosenberg, Ph.D. Igiz. Price \$1.50.

3. FARCA A MANERA DE TRAgedia. Edited by Hugo A. Rennert, Ph.D. Valladolid, 1914. Price \$1.00.

4. The SPANish Pastoral DRaMa. By J. P. Wickersham Crawford, Ph.D. 19×5. Price \$r.50.

5. COMEDIA FAMOSA DE LAS BURLAS VERAS DE IVLIAN DE ARMENDARIZ. By S. L. Millard Rosengerg, Ph.D. 1917. Price \$1.50.

6. The Dialects of Central Italy. By Herbert H. Vaughan, Ph.D. 19x6. Price $\$ 1.50$.

7. SPANISH DRAMA BEFORE LOPE DE VEGA. BY J. P. Wickersham CRAwFORD, Ph.D. 1922. Price \$2.00.

Copies may be obtained by addressing

Department of Romanic Languages

College Hall, University of Pennsylvania

Philadelphia, Pennsylvania 


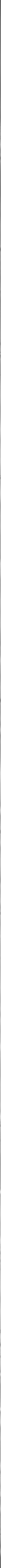




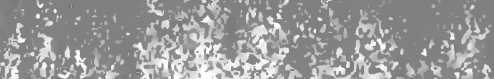

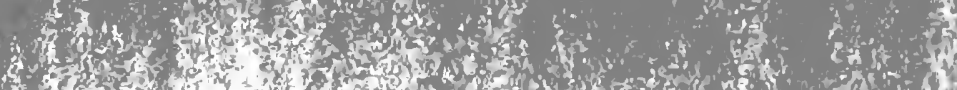

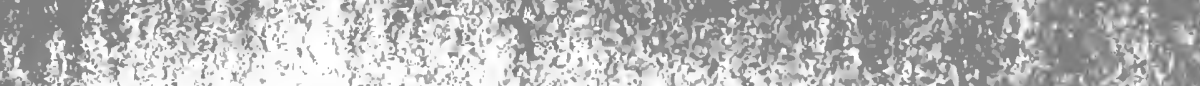
$4 \times x+3$ $\cos _{0}$

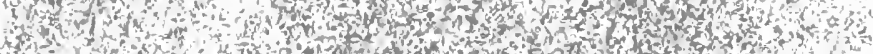

3.

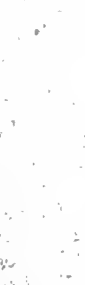

M 1 H.

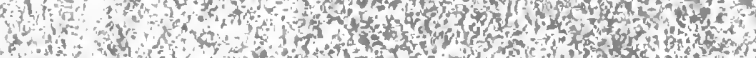

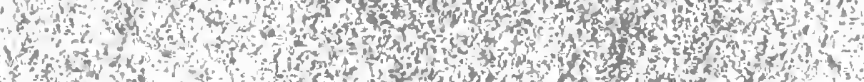

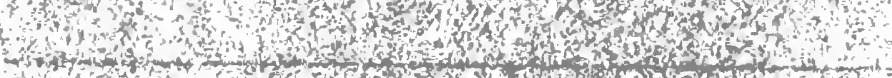

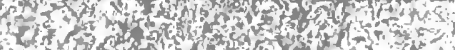

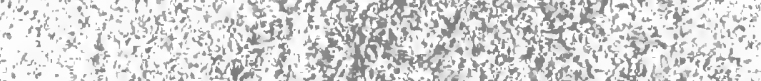

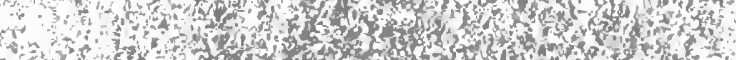

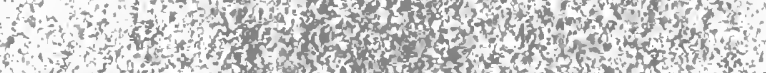

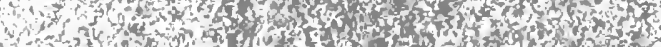

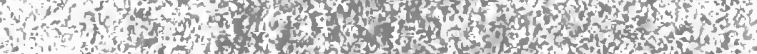

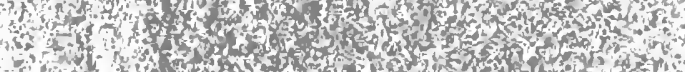
m. $\therefore$, w , of

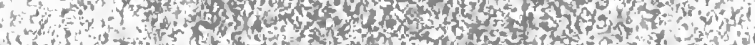

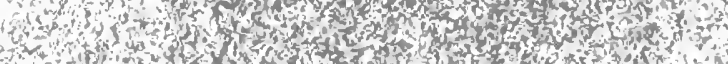

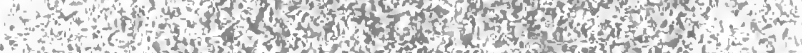

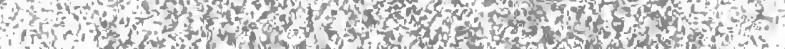

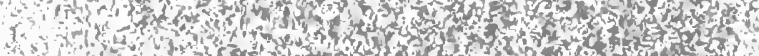

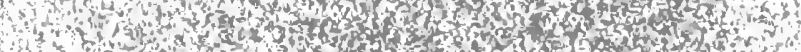

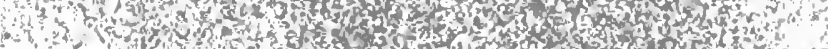

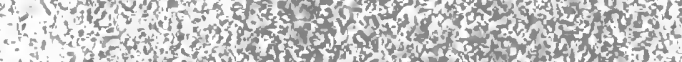

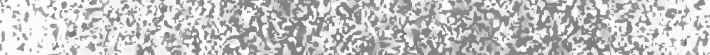

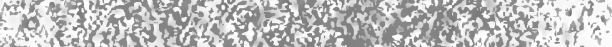

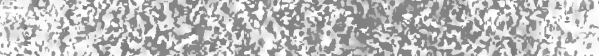

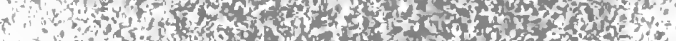

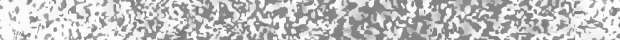

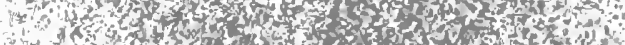

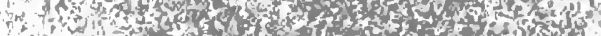

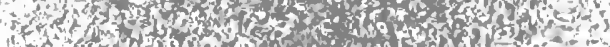

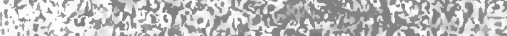

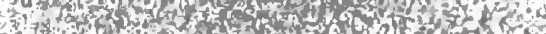

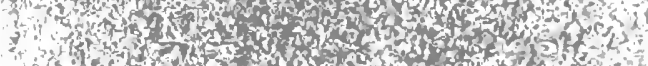

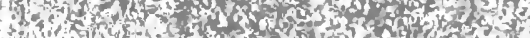

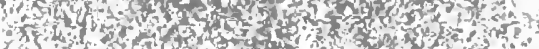

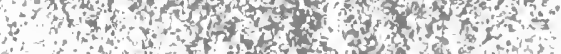

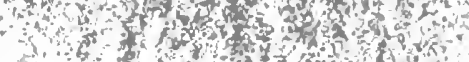




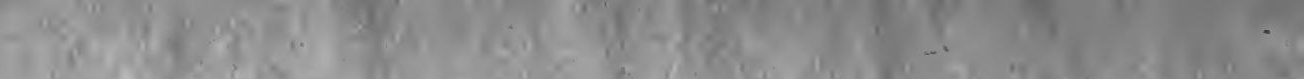

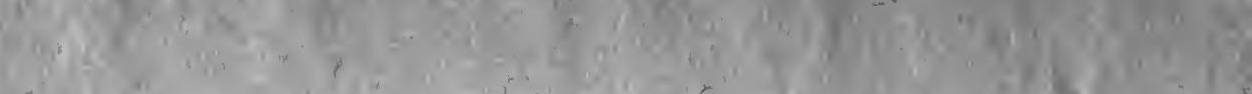

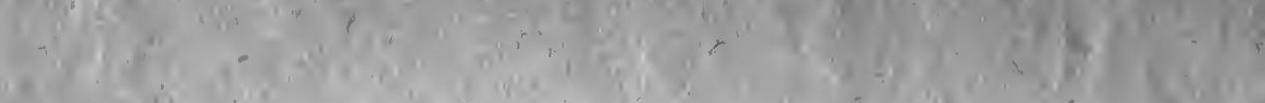
W

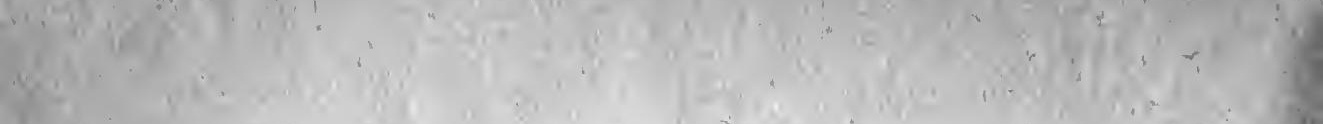

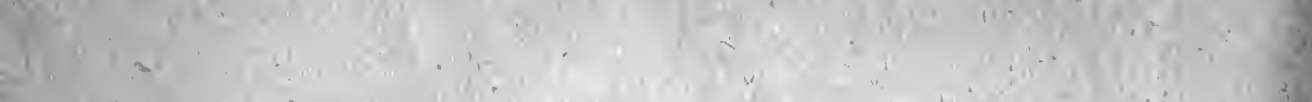

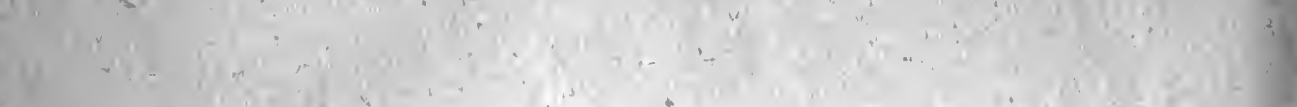
(1)

$i_{1}^{+}, 19$

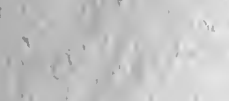

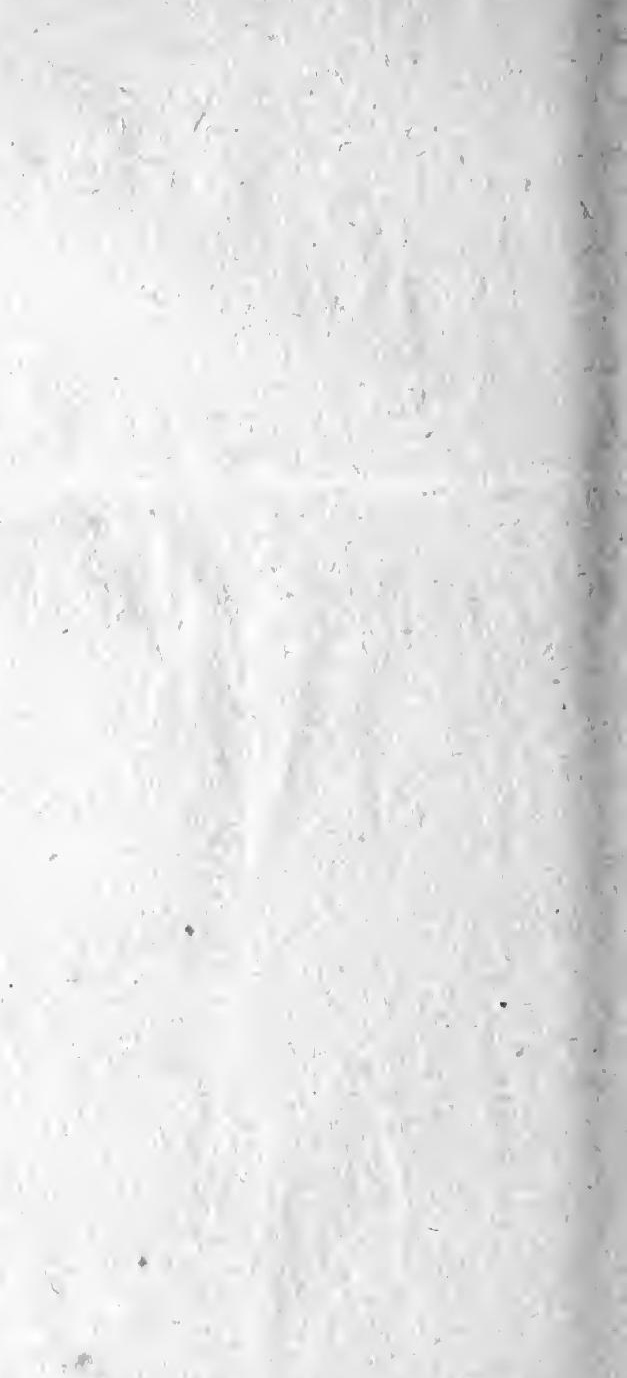
no:

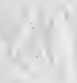

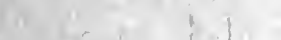

$\therefore+i+i$

$x^{3}+x^{2}+3$

$\left(\begin{array}{l}1 \\ i\end{array}\right.$

$7+\therefore=\quad \therefore \quad 1=$

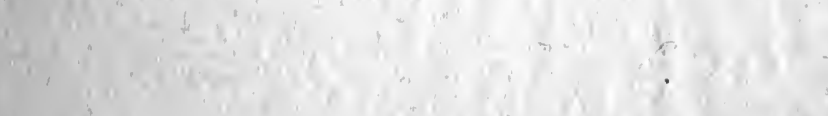

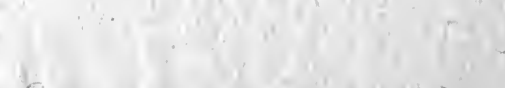

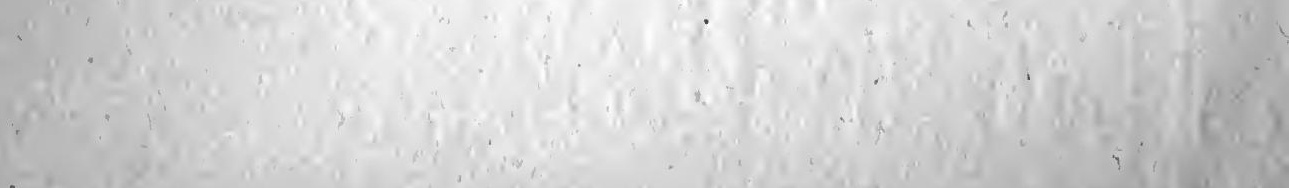





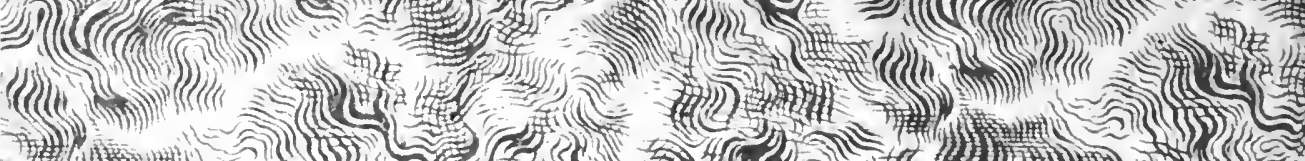

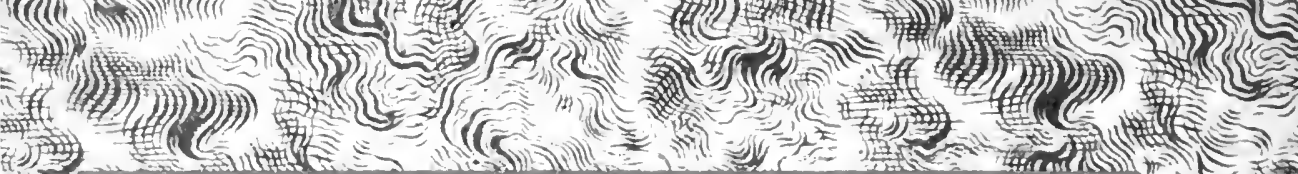
Hate

$P Q$

THE LIBRARY
6104 UNIVERSITY OF CALIFORNIA

C7 Santa Barbara

\section{STACK COLLECTION}

THIS BOOK IS DUE ON THE LAST DATE STAMPED BELOW.

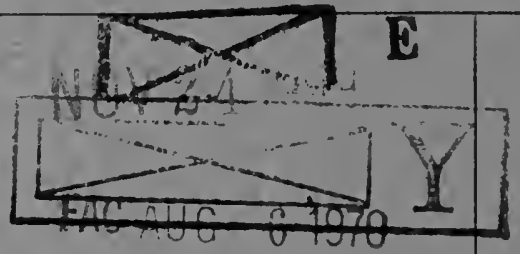

EACOCF 77970

\section{.}

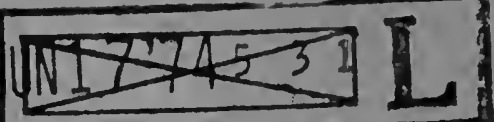

$30 m \cdot 8, ' 65(F 6447 s 4) 9482$

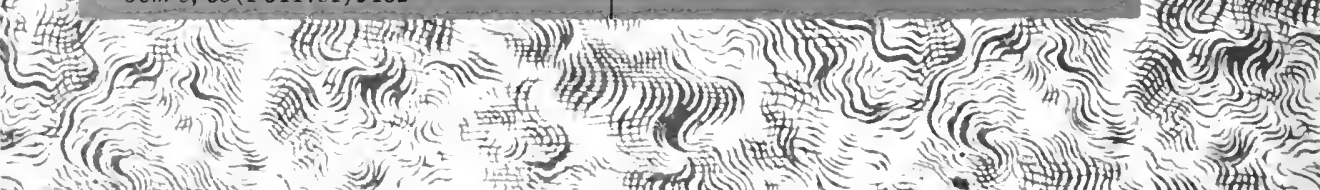

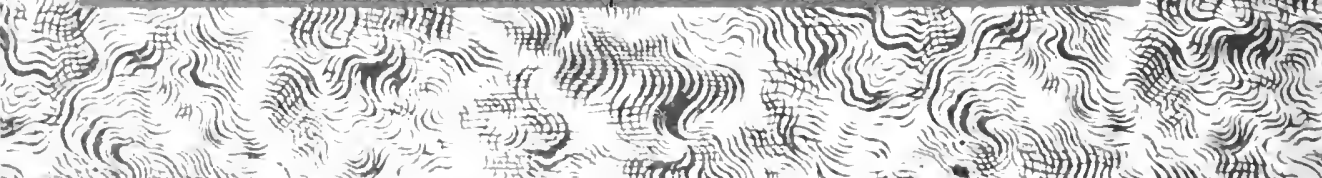
(a) $2(1)$ i) (1) (1) 1 (1) 舟) (e)

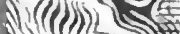

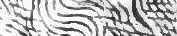
(7) 新) ins (101)

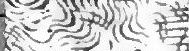
(i) 3) (2) (n) 年

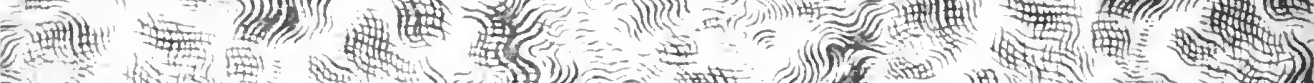

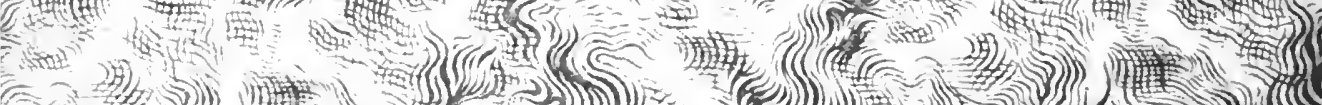
(1) 
